CASSIA MARIA BUCHALLA

\title{
A SÍNDROME DA IMUNODEFICIÊNCIA ADQUIRIDA \\ E A MORTAlidade MASCUlina, DE 20 a 49 ANOS, NO MUNICÍPIO DE SÃo PAULO.
}

1983 a 1986

Tese apresentada ao Departamento de Epidemiologia da Faculdade de Saúde Pública da Universidade de São Paulo para a obtençāo do Título de Doutor em Saúde Pública

Orientador: Prof.Dr. Ruy Laurenti

SÃo PAULO

1993

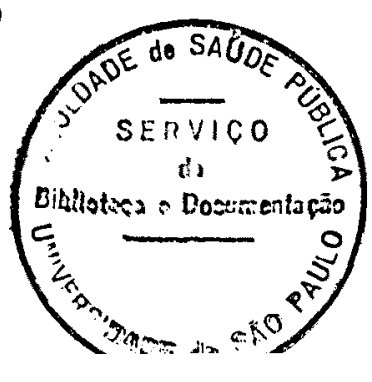


Este trabalho foi realizado, em parte, com o auxilio financeiro da FUNDAÇĀO DE AMPARO $\grave{A}$ PESQUISA DO ESTADO DE SÃO PAULO, FAPESP, processo 88/1610-3. 


\section{AGRADECIMENTOS}

Ao Prof. Dr. Ruy Laurenti, meu orientador, que sempre, além da orientação constante, incentivou-me a prosseguir.

Aos colegas do Centro Brasileiro de Classificação de Doenças, Profs. Drs. Cecilia Amaro de Lolio e Augusto Hasiak Santo, pela ajuda valiosa desde o início deste estudo.

À Dra. Dagmar Deborah Barbieri, do Centro de Referência e TreinamentoAIDS, amiga e colaboradora, que foi a ligação entre este estudo e a Vigilância Epidemiológica.

A amiga Maria do Rosário Dias de Oliveira Latorre pela ajuda na análise dos dados e pelas sugestões que permitiram melhorar este trabalho.

Aos Profs. Drs. Sabina Léa D. Gotlieb e José Maria Pacheco de Souza, do Departamento de Epidemiologia, que ajudaram na fase final.

Ao Fernão Dias de Lima que, pacientemente, atendeu minhas solicitações em relação ao banco de dados.

Aos demais colegas do Centro Brasileiro de Classificação de Doenças, D.Dalva Loria e Elizabeth Vieira dos Santos, pela colaboração em numerosas tarefas de ordem administrativas.

Aos colegas do Departamento de Epidemiologia, da Estatística e do "fundāo", que sempre estiveram disponíveis para esclarecer minhas inúmeras dúvidas.

Ao colega Dr. Luiz Augusto Marcondes Fonseca pela colaboração discutindo o tema.

À Heliana Martins Carreira, pela datilografia das referências bibliográficas.

À Angela Maria Belloni Cuenca, pela ajuda na correta anotação das referências bibliográficas.

Finalmente, à minha família e aos meus amigos que puderam compreender o tempo que deixei de estar com eles para me dedicar a este estudo. 


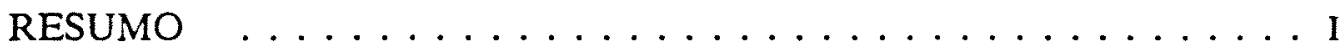

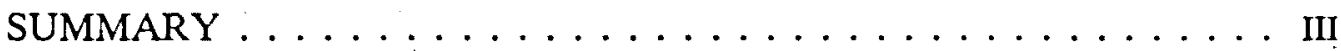

ABREVIATURAS UTILIZADAS $\ldots \ldots \ldots \ldots \ldots \ldots$

INTRODUÇÃO . . . . . . . . . . . . . . . . 1

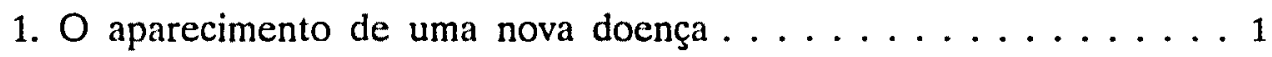

2. A história natural da doença $\ldots \ldots \ldots \ldots \ldots \ldots \ldots$

3. $\mathrm{O}$ agente etiológico : um novo vírus $\ldots \ldots \ldots \ldots \ldots \ldots$

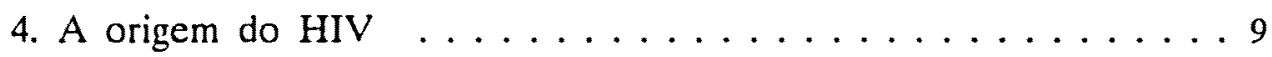

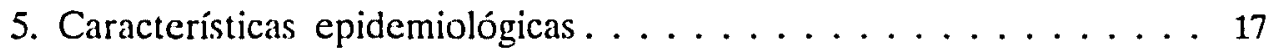

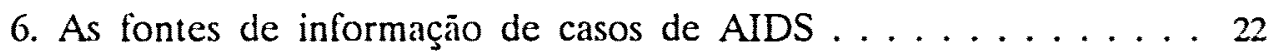

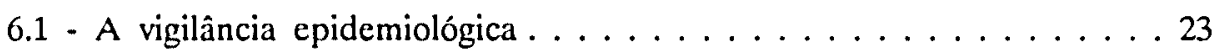

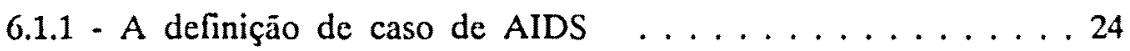

6.1.2 - Os problemas da subnotificação de casos . . . . . . 26 26

6.2 - O atestado de óbito . . . . . . . . . . . . . . . . 29

6.2.1 - As regras para seleção da causa de morte . . . . . . 30

6.2.2 - Os problemas de omissão da verdadeira causa da morte . . 33

OBJETIVOS ...................... 37

MATERIAL E MÉTODOS ... . . . . . . . . . . . . 39

- Lista das doenças mencionadas nos atestados de óbito e que serviram para a seleção dos casos do estudo . . . . . . . 46

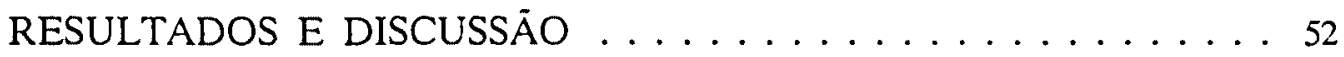

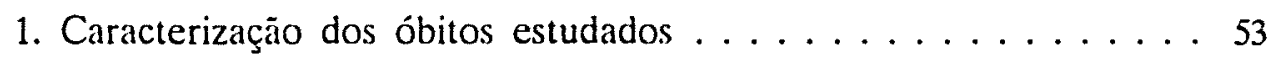

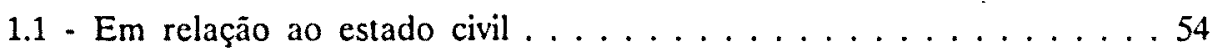

1.2 - Em relação ao local de ocorrência . . . . . . . . . . . 54

1.3 - Em relação à idade $\ldots \ldots \ldots \ldots \ldots \ldots \ldots \ldots \ldots$

$1.4-\mathrm{Em}$ relação à ocupação $\ldots \ldots \ldots \ldots \ldots \ldots \ldots \ldots \ldots$

1.5 - Em relaçāo ao grau de instruçāo $\ldots \ldots \ldots \ldots \ldots \ldots \ldots$

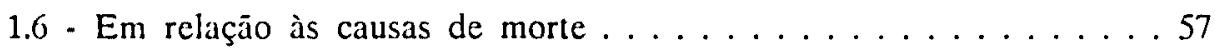

2. Caracterização dos óbitos identificados neste estudo

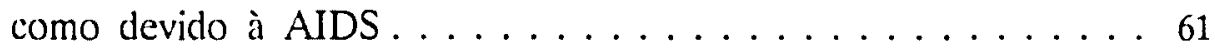

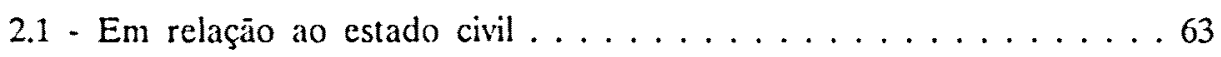


2.2 - Em relação ao local de ocorrência . . . . . . . . . . . 65

2.3 - Em relação ao hospital de ocorrência do óbito . . . . . . . . 66

2.4 - Em relação à idade . . . . . . . . . . . . . 66

$2.5-$ Em relação à ocupação $\ldots \ldots \ldots \ldots$. . . . . . . . . 68

2.6 - Em relação ao grau de Instrução . . . . . . . . . . 73

2.7 . Em relação às causas de morte . . . . . . . . . . . 73

2.7.1 - AIDS e doenças associadas . . . . . . . . . 76

2.7 .2 - Tuberculose . . . . . . . . . . . . . . . 77

2.7 .3 - Pneumonias e broncopneumonia . . . . . . . . 80

2.7 .4 - Linfossarcomas e linfomas . . . . . . . . . . . . . 82

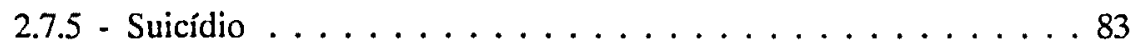

2.7.6 - Todas as Demais Causas de Morte . . . . . . . . . . 83

3. A notificação dos casos . . . . . . . . . . . . . . 85

3.1 - Casos de AIDS não notificados e identificados pelo estudo . . . . . 88

3.1 .1 - Em relação à idade . . . . . . . . . . . . . 88

3.1 .2 - Em relação ao estado civil . . . . . . . . . . . . . . 89

3.1.3 - Em relação ao local de ocorrência do óbito . . . . . . 990

3.1.4 - Em relação ao hospitais onde ocorreram os óbitos . . . . .990

3.1.5 - Em relação à ocupação e grau de Instrução . . . . . . . 91

3.1.6 - Em relação à causa básica do óbito . . . . . . . . . 93

3.2 - A identificaçāo dos casos onde a causa básica da morte

era uma doença diferente das selecionadas para o estudo . . 96

3.3 - Os motivos de sub-notificação de casos de AIDS . . . . . . . . . . 99

4. A notilicaçĩo dos óbitos por AIDS . . . . . . . . . . . . 103

5. Conclusões e considerações finais . . . . . . . . . . . 107

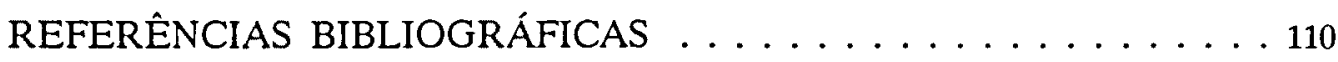

ANEXOS . . . . . . . . . . . . . . . . . . . . . . 119

- ANEXO 1 - A definição de caso de AIDS dos "CENTERS FOR DISEASE CONTROL" revisão de 1987 . . . . . . . A-1

- ANEXO 2 - Sistema de classificação para a infecção pelo HIV em adultos . . . . . . . . . . . . . . A -5

- ANEXO 3 - Revisão da definição nacional do caso de AIDS em adultos $\ldots \ldots \ldots \ldots \ldots \ldots \ldots \ldots$ A $-8 \ldots \ldots$ 


\section{RESUMO}

Com a finalidade de conhecer a história da epidemia de AIDS no Município de São Paulo, analisou-se a mortalidade pela síndrome, de 1983 a 1986.

Utilizando a metodologia de revisão dos atestados de óbito, foi possível conhecer algumas características desses indivíduos e detectar casos de AIDS não notificados ao sistema de vigilância epidemiológica. Foram revistos os atestados de óbito de indivíduos do sexo masculino, de 20 a 49 anos, que faleceram no Município de São Paulo, de 1983 a 1986.

Os atestados foram selecionados pela causa básica, onde esta era AIDS, imunodeficiência, doenças indicativas de AIDS ou infecçōes oportunistas e outras patologias que poderiam estar mascarando casos de AIDS.

Entre 4023 atestados selecionados, 359 se referiam a AIDS e, destes, 305 (85\%) eram óbitos de casos notificados e 54 (15\%) óbitos de casos não notificados. No grupo não notificado, a AIDS, ou apenas imunodeficiência, era causa básica 
em 26 declarações de óbito e em outras 10 ela era mencionada, ainda que não como causa básica.

Os 54 casos identificados pelo estudo representam um aumento de $7 \%$ no número de casos de AIDS do Município de São Paulo e de 7,3\% no número de óbitos pela doença, neste mesmo local, sendo que a letalidade da AIDS passa de $77,8 \%$ para $79,3 \%$ no período considerado.

Os casos detectados de AIDS eram em sua maioria indivíduos solteiros $(81,9 \%)$, jovens (58\% tinham de 20 a 34 anos) e que faleceram em hospitais (95,3\% dos óbitos). As profissōes mais referidas foram de bancário e economiário (6,7\% dos atestados), auxiliar de escritório (6,4\%), seguidas de cabeleireiro $(5,3 \%)$ e de comerciante $(3,9 \%)$. Entre os casos não notificados havia maior freqüência de indivíduos com nível superior de educação em relação aos que não tinham sido notificados. 


\section{SUMMARY}

To assess the history of AIDS epidemics in the City of São Paulo, we analysed the mortality of this syndrome, from 1983 to 1986.

Underreported AIDS cases were detected thru reviewing death certificates. Those from 20 to 49 years old males were reviewed.

Deaths from AIDS, immunodeficiency or other diseases that seemed to be AIDS cases, were selected and analysed in reference to age, occupation, case reporting to the surveillance system and the diseases mentioned in the death certificates.

Three hundred and fifty nine death out of 4023 death certificates were caused by AIDS. Of these, $305(85 \%)$ were cases reported to the surveillance system. AIDS or immunodeliciency were mentioned in 54 deaths not reported as AIDS cases and this disease was the underlying cause of death in 26 of them and in 10, AIDS was mentioned but not as the underlying cause of death. 
Those 54 cases identified by this study increases $7 \%$ the number of AIDS cases in the City of São Paulo and 7,3\% the deaths caused by this syndrome. The letality increases from $77,8 \%$ to $79,3 \%$ in the period considered.

The AIDS cases identitied in this study were of young men $(58 \%$ were between 20 and 34 year old) and single males (81,9\%) and the death occurred in the Hospital (95,3\%). The most frequent occupation were bank clerks $(6,7 \%)$, office clerks $(6,4 \%)$, hairdressers $(5,3 \%)$ and commercial workers (3,9\%). Among underreported cases there were more people with university degrees. 


\section{ABREVIATURAS UTILIZADAS NESTE TRABALHO}

AIDS

$\mathrm{AO}$

CB

CDC

CID

CVE

DO

DST

ELISA

EUA

IIIV

Min.S.

MMWR

OMS

PIC

SK

SVE

WB
Síndrome da Imunodeficiência Adquirida

Atestado de Óbito

Causa Básica da Morte

Centers for Disease Control (Centros de Controle das Doenças, de Atlanta, EUA)

Classificação Internacional de Doenças

Centro de Vigilância Epidemiológica "Prof. Alexandre

Vranjac" da Secretaria de Estado da Saúde de São Paulo

Declaraçāo de Óbito

Doença Sexualmente Transmissível

Ensaio Imunoenzimático

Estados Unidos da América

Vírus da Imunodeficiência Humana

Ministério da Saúde do Brasil

Morbidity and Mortality Weekly Report

Organizaçāo Mundial da Saúde

Pneumonia por Pneumocystis carinii

Sarcoma de Kaposi

Sistema de Vigilância Epidemiológica

"Western Blot" 
INTRODUÇÃO 


\section{INTRODUÇĀO}

\section{1 - O APARECIMENTO DE UMA NOVA DOENÇA}

Em 5 de junho de 1981 o boletim MMWR dos Centros para o Controle

de Doenças, de Atlanta, EUA (Centers for Disease Control-CDC) ${ }^{40(*)}$ publicou um artigo relatando a ocorrência de cinco casos de Pneumonia por Pneumocystis carinii em indivíduos previamente saudáveis; diagnosticados em Los Angeles, Califórnia, entre outubro de 1980 e maio de 1981.

O Pneumocystis carinii, habitualmente tido como um protozoário (embora estudos recentes tenham mostrado que seu DNA se assemelha muito ao dos fungos), é praticamente inofensivo em situações onde não há comprometimento da imunidade, porém. é capaz de causar pneumonias em casos em que há deficiência do sistema imunológico, particularmente devida ao câncer, ao transplante

(*) A sigla CDC, de Centros para o Controle de Doenças, é utilizada, neste estudo, no singular, assim como em suas próprias publicações ${ }^{20}$. 
renal ou em conseqüência de terapia imunossupressora.

Algumas das características presentes naqueles cinco pacientes chamaram a atenção, como o fato de todos serem homossexuais com história de intensa atividade sexual e apresentarem um quadro de imunodeficiência que propiciava a instalação de outras infeç̧ões, como citomegalovirose e candidíase.

A esta primeira publicação seguiu-se outra, de 3 de julho de 1981, no mesmo boletim, sobre a ocorrência de Sarcoma de Kaposi (SK) e Pneumonia por Pneumocystis carinii PPC) em 26 homossexuais masculinos de Nova York e da Califórnia $^{36}$.

De acordo com esse artigo, após uma revisão no Registro de Câncer de Nova York, conseguiu-sc identificar 3 casos de SK em homens com idade inferior a 50 anos ocorridos no Hospital da Universidade de Nova York, no periodo de 1961 a 1979. Os autores descrevem os vários tipos de infecção que acometeram esses 26 indivíduos, tais como a Pneumonia por Pneumocystis carinii, a ocorrência de toxoplasmose necrotizante do sistema nervoso central, os casos de infecção grave e recidivante por herpes simples assim como casos de candidíase extensa e de meningite por criptococo.

Outra característica importante encontrada nesses que seriam os primeiros casos da síndrome de imunodeficiência adquirida foi a alta prevalência de infecção por citomegalovirus, o que foi evidenciado, sorologicamente, em todos os 12 individuos que foram testados e identificado, por meio de cultura, em outros 3 pacientes.

Entre os quinze primeiros casos de PPC que caracterizaram o início da epidemia, $9 \mathrm{em}$ Los Angeles e $6 \mathrm{em}$ San Francisco, dois apresentaram, também, SK, um tipo de câncer de vasos sangüineos da pele, mais lreqüente, até então, em pessoas idosas, nas quais o quadro não tem características graves. 
As duas publicações citadas registraram as primeiras manifestações de uma nova doença que iria causar transtorno, não apenas no meio médico mas na sociedade como um todo, a partir do início da década de oitenta.

A principal característica comum aos individuos doentes, a diminuição da resposta imunológica celular que os tornava suscetíveis a doenças causadas por agentes normalmente de baixa patogenicidade, levou à denominação desta nova entidade de Síndrome da Imunodeficiência Adquirida (SIDA ou AIDS, do inglês, Acquired Immunodeficiency Syndrome).

O termo SIDA, abreviatura da tradução ao português, embora seja o correto e o termo empregado nos demais países de língua latina, raramente é utilizado em nosso país. Desta forma, por facilidade e homogeneidade com o uso corrente em nosso meio, neste trabalho utiliza-se a sigla em inglês, AIDS.

O quadro conhecido como Síndrome da Imunodeficiência Adquirida consiste em alteraçōes do sistema imunológico, responsável pelas defesas do organismo, que permitem a instalação de quadros infecciosos, os quais passaram a ser denominados de infecções oportunistas.

A droga utilizada para o tratamento da PPC, presente nos primeiros casos de AIDS, era controlada pelo CDC e o aumento no número de pedidos desse medicamento levou essa Instituição a iniciar a primeira investigação sobre a nova doença.

Ao se definirem algumas características epidemiológicas da AIDS notou-se que, a princípio, a síndrome acometia individuos do sexo masculino, adultos jovens, homossexuais com intensa atividade sexual e grande número de parceiros. Esta característica levou, inicialmente, a se considerar a AIDS como limitada a este grupo e o meio de transmissão sexual como a provável via de contaminação.

Os primeiros casos de imunodeficiência adquirida diagnosticados em San 
Francisco, Califórnia, aconteceram em indivíduos que, coincidentemente, haviam participado de um estudo sobre hepatite $B$, uma doença cuja transmissão também pode ocorrer por via sexual. Este fato chamou a atenção do serviço de vigilância epidemiológica que constatou que, em 1982, 42\% dos casos de AIDS notificados naquela cidade eram ex-participantes do estudo de hepatite $\mathrm{B}^{43,88}$. Por analogia passou-se a investigar a possibilidade de transmissão sexual da nova doença ${ }^{10}$.

Assim, como outras doenças de transmissão sexual são causadas por vírus, a hipótese de um agente viral que levasse à imunodeficiência celular foi levantada e aceita até que estudos pudessem comprovar o real agente etiológico.

No decorrer das investigaçōes epidemiológicas realizadas pelo CDC, foram relatados casos de AIDS em indivíduos portadores de hemofilia. Quando surgiram casos pós-transfusionais demonstrando que o sangue contaminado exercia um importante papel na incidência desta nova doença, ficou caracterizada a transmissão sangüínea, por transfusão de sangue ou seus componentes.

Assim, com mais esta possibilidade de contaminação, foram registrados casos em número cada vez maior, não apenas nos grandes centros urbanos, como havia ocorrido no princípio da epidemia, mas também em outras localidades dos Estados Unidos da América.

Nesta fase de conhecimento da doença, mesmo antes de se ter isolado o agente, a AIDS já havia sido identificada em muitos países. $O$ elevado número de casos em alguns países africanos assim como a alta prevalência da infecção pelo vírus da imunodeficiência adquirida (HIV) nessas populações, levaram à hipótese do agente ter se originado naquele continente.

No Brasil, a epidemia apareceu no início da década de oitenta em grandes centros urbanos como São Paulo e Rio de Janeiro, atingindo, em um primeiro momento, indivíduos de nível sócio-econômico médio e alto, em sua maioria 
profissionais liberais e artistas. Presume-se que esses primeiros pacientes tenham sido contaminados fora do país.

Em 1982, foi diagnosticado em São Paulo o primeiro caso autóctone da síndrome. seguido do aparecimento de um número cada vez maior de casos, inclusive de outras cidades do país ${ }^{2}$.

\section{2 - A HiSTÓRIA NATURAL DA DOENÇA}

A infecção pelo HIV pode se manifestar de várias maneiras, sendo que há possibilidade de longos períodos assintomáticos ${ }^{54}$.

Após a infecção, o indivíduo pode, ou não, apresentar uma fase aguda, com um quadro semelhante a mononucleose infecciosa. Neste início, nāo há, ainda, a presença de anticorpos. No período de 2 a 8 semanas após a infecção esses anticorpos aparecem no sangue, porém foram descritos casos nos quais só foi possível detectar os anticorpos específicos muitos meses após a infecçāo ${ }^{46,54,86}$.

O portador pode ficar assintomático por muito tempo, talvez mais do que dez anos, até o aparecimento das primeiras manifestações de doenças oportunistas ou outras alteraçōes ocasionadas pelo vírus ${ }^{42}$. A infecção pelo HIV pode evoluir para o quadro de doença que se manifesta tanto através de doença constitucional, como por quadros neurológicos ou neoplasias secundárias.

O sistema de classificação para a infecção pelo HIV em adultos, proposto pelo $\mathrm{CDC}$ em 1989. e que serviu de referência neste estudo, encontra-se no anexo 2 , 
embora, em dezembro de 1992, tenha sido publicada, também pelo CDC, uma nova revisão do sistema de classificação da infecção pelo HIV e definição de caso de AIDS em adolescentes e adultos, para fins de vigilância ${ }^{20}$.

\section{3 - O AGENTE ETIOLÓGICO: UM NOVO VÍRUS}

Pesquisadores direcionaram seus esforços na identificação do provável agente etiológico, o que culminou com o isolamento de um retrovírus por uma equipe do Instituto Pasteur de Paris dirigida pelo Dr. Luc Montagnier, em 1983, que o denominou LAV (Lymphoadenopathy associated virus - Vírus da linfadenopatia associada) ${ }^{7}$.

No ano seguinte, o Dr.Robert Gallo, do Instituto Nacional de Câncer dos EUA, conseguiu isolar um retrovírus que chamou de HTLV-III (Human T-cell lymphotropic virus type III), pois, anteriormente, já havia isolado outros dois tipos de retrovírus humano ${ }^{38,81}$.

Concluiu-se, mais tarde, que estes dois retrovirus, o LAV e o HTLV-III tinham características bastante semelhantes e, na verdade, eram o mesmo vírus. Desta forma, em 1986 o International Committee for the Taxonomy of viruses atribuiu a esse retrovírus. isolado tanto na França como nos EUA, o nome de HUMAN IMMUNODEFICIENCY VIRUS ou $\mathrm{HIV}^{23}$.

Existem dois grandes grupos de retrovírus patogênicos para o homem: o vírus da imunodeficiência humana - HIV - que se subdivide em HIV-1 e HIV-2, agentes da AIDS e o grupo do HTLV (vírus linfotrópico das células T), HTLV-I e HTLV-II, 
que causam a leucemia de células $\mathrm{T}$, linfomas e doenças neurológicas ${ }^{28,39}$.

O HIV é um retrovírus da família-lentiviridae que se caracteriza por sintetizar DNA a partir de RNA pela presença de uma enzima - a transcriptase reversa - específica dos retrovírus ${ }^{33}$. Os lentivírus têm propensão à citólise e são chamados virus lentos porque se replicam vagarosamente e induzem a doenças debilitantes ${ }^{39}$.

Estes vírus, por mecanismos específicos, fixam-se a receptores de determinadas células, como linfócitos, monócitos e macrófagos, onde penetram e utilizam o material genético destas células para sua replicaçāo. Existem fortes evidências de que o vírus se mantém latente por um período de tempo prolongado, tanto em linfócitos como nos monócitos ${ }^{33}$.

Uma vez dentro da célula, tendo incorporado seu material genético, o retrovírus pode se reproduzir imediatamente ou ficar em estado de dormência por tempo indeterminado. $O$ genoma viral fica integrado ao cromossoma da célula por uma associação permanente. Assim, se a célula se reproduz, vai reproduzir o DNA do vírus ${ }^{39}$.

Recentemente, foram publicados relatos de casos de imunodeficiência adquirida nos quais não foi possivel detectar evidências de infecção pelo HIV. Estes casos, em número pequeno, encontram-se em investigação, porém a possibilidade de ocorrência da doença sem a presença de um agente conhecido reforça as preocupações em relação às medidas de prevenção e, principalmente, sobre o controle do sangue ${ }^{10,52}$. 


\section{4 - A ORIGEM DO HIV}

Um dos grandes desafios entre os que se apresentaram aos pesquisadores desde o advento desta nova doença foi explicar a origem deste vírus tão devastador. No momento em que se concluiu ser a AIDS ocasionada por uma infecção viral, depois do isolamento do vírus, sua origem foi, e até os dias atuais continua sendo, um grande enigma.

Pelo fato de ser elevada a incidência da doença em alguns países da África Central e pelas indicações da presença de um vírus semelhante ao HIV, causador da imunodeficiência em populações de macacos daquele continente, muitos pesquisadores acreditam que o HIV tenha se originado nessa região da África, onde deveria existir em populações delimitadas, há muito tempo.

Vários estudos corroboram esta idéia e, principalmente, o fato do vírus ter sido isolado de amostras de plasma utilizadas em outros estudos e datadas da década de cinquenta. NAHMIAS e colaboradores ${ }^{71}$ (1986) submeteram a testes laboratoriais 1213 plasmas coletados anteriormente para outros estudos. Analisando amostras desse material, de vários locais do continente africano, concluíram que o vírus já existia, embora com baixa prevalência, no Zaire, em 1959. O estudo indica que a infecção poderia existir em locais delimitados tendo se alastrado, vagarosamente, aos países vizinhos.

Um fator bastante importante no estudo da origem do HIV foi a elevada incidência de casos na África Central, em 1986, quando a taxa anual foi de 550 a 1000 casos para cada um milhão de habitantes adultos. Nesta área, a prevalência de testes sorológicos positivos foi de até $18 \% \mathrm{em}$ doadores de sangue e em mulheres grávidas e chegou a $88 \%$ em prostitutas ${ }^{85}$. 
Como já foi citado, o isolamento de um outro retrovírus, o STLV-III, que pode causar imunodeficiência em algumas espécies de macacos da África, veio fortalecer ainda mais a hipótese da origem africana do HIV.

O STLV-III, segundo alguns pesquisadores, parece bastante semelhante a outros retrovírus, entre eles o HTLV-IV, vírus da mesma família do HIV e identificado em prostitutas do Senegal ${ }^{85}$. Além dessa semelhança com o HTLV-IV, o STLV-III tem em sua composição a mesma seqüência de polinucleotídeos que tem o HIV-2, outro retrovírus causador de imunodeficiência adquirida e isolado em pacientes com AIDS ou portadores de HIV-1 $28,32,33$.

O HIV-2 foi isolado na África Ocidental, em 1985, depois que foram obtidas reaçōes aberrantes ao teste para o HIV-1 e também ao SIV(Vírus da imunodeficiência símia). Este novo retrovirus é, genética e antigenicamente, mais próximo do SIV do que do HIV-1 sendo que seu genoma é $70 \%$ semelhante ao do SIV, apresentando apenas $40 \%$ de seqüência igual ao do HIV-1. Apesar deste fato, estudos mostram que os dois vírus da imunodeficiência humana têm origem comum e provavelmente tiveram seu início há mais ou menos 40 anos atrás ${ }^{93}$.

A etiologia viral e a provável origem africana explicam a grande incidência de AIDS naquele continente e podem, também, justificar a disseminação deste agente para a Europa e Américas, quando mudanças políticas em alguns países africanos tornaram possível uma mobilização de indivíduos para outros continentes assim como um fluxo de trabalhadores de outros locais para a África Central. A ocorrência deste trânsito que interligou países como Zaire com países da Europa e da América, principalmente o Haiti, é hoje uma hipótese plausível para explicar a disseminação do vírus ${ }^{97}$.

O padrão de transmissão verificado na África se caracteriza pela alta incidência de casos da doença em pessoas de ambos os sexos e em todas as faixas de idade ${ }^{79}$. Esta alta incidência pode ser explicada pela falta de condições 
adequadas de assistência à saúde, pela extrema pobreza em que se encontra grande parte da população daquele continente e pelos hábitos culturais.

ANKRAH ${ }^{4}$ (1989) descreve, em seu estudo sobre o aparecimento da AIDS em Uganda, como as crenças populares podem influir na disseminação de doenças infecciosas. Os primeiros casos da síndrome nesse país foram de pescadores que faleceram pouco tempo após o diagnóstico da doença, apesar de terem recebido cuidados médicos. A alta letalidade fez com que a população acreditasse que esta doença era decorrência de feitiçaria realizada pelos tanzanianos, povo freqüentemente enganado pelos pescadores que faziam o contrabando de bens através do Lago Vitória. Quando foram diagnosticados casos nas esposas e nos filhos destes pescadores, a população passou a acreditar que o feitiço não visava as pessoas, mas o local, o que fez com que a população abandonasse esse porto indo para cidades vizinhas ${ }^{4}$.

Outro fato importante foi a prática, comum nos serviços de saúde de países pobres, da reutilização de seringas, muitas vezes mal esterilizadas. A grande demanda aos serviços médicos e a escassez de recursos humanos e linanceiros tornaram a AIDS mais um entre os muitos problemas a serem enfrentados.

A religião também favoreceu a disseminação do agente pois em alguns ritos religiosos africanos são feitas escarificações na pele dos participantes. Estas são realizadas em seqüência durante a cerimônia, sempre com o mesmo instrumento, sem qualquer limpeza.

A elevada incidência da AIDS entre os povos africanos pode ainda ser explicada pelo tipo de relação marital. Em alguns países daquele continente as relações monogâmicas sāo raras, predominando relaçōes pouco duradouras, com um número grande e concomitante de parceiros sexuais. Esses fatos colaboram para a disseminação de doenças de transmissão sexual, o que se confirma pelo elevado número de casos de sífilis, assim como de outras doenças sexualmente 
transmissiveis. Sabe-se que a ocorrência de infecção pelo HIV está fortemente associada a outras DST.

No início do ano de 1985, passou-se a usar o teste ELISA (ensaio imunoenzimático) para detectar anticorpos anti-HIV. A utilização de um teste diagnóstico permitiu a identificação dos indivíduos contaminados, assim como um melhor conhecimento da história natural da doença.

O teste possibilitou detectar anticorpos específicos, identificando a presença do vírus e sua origem. Desta forma identificaram o vírus em soros de 1959 no Zaire, um dos locais de maior incidência da doença ${ }^{79}$.

A utilização dos testes abriu uma nova perspectiva de abordagem da AIDS, permitiu o controle do sangue e, assim, diminuiu a transmissão pelas transfusões. Foi também importante para se conhecer indivíduos contaminados e, com medidas preventivas, se tentar o controle da transmissão.

Ao ELISA seguiu-se o Western Blot (WB) que permite, através da eletroforese, detectar a existência de proteínas virais no sangue. Sendo um teste com maior especificidade que o ELISA, é preconizado como teste confirmatório. Além destes, foram sendo desenvolvidos novos testes diagnósticos assim como exames com finalidade de identificar as demais alteraçōes ocasionadas pelo HIV ao organismo.

A possibilidade de voltar atrás no tempo e recuperar, através dos testes diagnósticos, informações de anos anteriores permitiram conhecer a história natural da AIDS. Numerosos estudos utilizaram material de outras pesquisas realizadas no passado, como no caso do estudo sorológico sobre prevalência, incidência e prevenção de hepatite $B$, iniciado em 1978 nos $E_{U A}^{43,88,94}$.

Desta forma, amostras sangüíneas retiradas entre 1978 e 1980, de indivíduos 
homossexuais e bissexuais, população de maior risco para a hepatite $B$, foram submetidas ao teste para detectar anticorpos anti-HIV. Assim pôde se conhecer a existência do agente etiológico da AIDS nos EUA, antes da década de oitenta e, também, definir um provável período de incubação do vírus, pelo seguimento daqueles indivíduos cujo teste resultou positivo $43,88,94$.

Alguns estudos interessantes mostram a ocorrência de infecção pelo HIV fora do continente africano, em épocas anteriores à década de oitenta. Entre estes, um relata a ocorrência de um caso em Manchester, Inglaterra, em 1959 e outro descreve casos de uma estranha doença que dizimou uma familia na Noruega em 1976.

Em 1960, WILLIAMS e colaboradores ${ }^{98}$ (1983) publicaram dados sobre um caso de PPC e de citomegalovirose em um jovem de 25 anos que faleceu em setembro de 1959. A história clínica e o fato de o jovem ter estado na África levaram os autores a uma investigação maior, submetendo o material de autópsia a testes laboratoriais específicos e comprovou-se que todas as amostras examinadas resultaram positivas para o $\mathrm{HIV}^{27,98}$.

Assim como este, os demais casos puderam ser comprovados posteriormente, com o advento dos testes. Os três casos de AIDS na Noruega, que teve início com o pai, um marinheiro que havia estado na África, onde se contaminou e transmitiu à mulher e esta, ao engravidar transmitiu à filha. Desta forma, de 1966 à 1976, período que estas pessoas estiveram doentes, muito antes de ser conhecida a síndrome de imunodeficiência adquirida, já existiam casos esporádicos. No caso particular desta família, as três pessoas receberam diversos tipos de tratamento, por um longo período, que terminou com a morte de todos no ano de $1976^{37}$.

Uma investigação iniciada a partir de um resultado de teste positivo para o HIV-2, em um banco de sangue da França, em 1985, concluiu que o indivíduo havia se contaminado na Guiné-Bissau onde esteve entre 1966 e 1969. O fato desta pessoa doar sangue regularmente permitiu que se investigassem os receptores 
de seu sangue e assim definir o período de incubação do vírus naqueles casos com teste positivo e que ainda estavam vivos: entre 14 e $16 \operatorname{anos}^{32}$.

Em um estudo sobre a ocorrência de AIDS antes de 1980, através da revisão da literatura médica, de 1950 a 1986, HUMINER e colaboradores ${ }^{45}$ (1987) selecionaram artigos que relatavam casos clínicos onde houvesse a indicação de deficiência de imunidade celular, sem causa definida, ou a ocorrência das demais doenças oportunistas. Selecionaram as publicaçōes que relatavam casos publicados antes de 1981 e casos publicados após 1981, cujo diagnóstico havia sido feito antes de 1978 ou entre 1978 e 1981. Todos os casos selecionados deveriam obedecer à definição de caso de AIDS proposta pelo CDC. $O$ caso mais antigo identificado foi de 1952 tendo sido notificado em 1953 como uma pneumonia por citomegalovírus em um indivíduo do sexo masculino, de 28 anos de idade, nos EUA ${ }^{45}$.

Ostudo cita também 19 casos que poderiam ser AIDS, ocorridos nesse período em vários países. Três dos artigos selecionados relatavam SK disseminado e presença de outras doenças infecciosas, entre estas, cinco casos de PPC, sempre em individuos jovens, sendo 12 homens e 7 mulheres ${ }^{45}$.

Estes relatos sugerem a provável existência de casos de AIDS em alguns locais, mesmo antes de ser caracterizada a pandemia. Alguns deles levam a crer que o vírus originou-se na África e espalhou-se nos países da Europa e nos Estados Unidos, onde o primeiro caso detectado foi denominado "paciente zero" 78 . Este indivíduo teria se infectado por contato sexual com um africano, em 1977 em Paris, e teria levado o vírus para os EUA, sendo o responsável pela disseminação deste agente em vários locais do país. Acredita-se que, dos primeiros 248 casos notificados nos EUA, 40 foram contaminados pelo "anjo da morte" como foi denominado este jovem pois, ainda que soubesse o meio de transmissão do vírus, continuou a ter numerosos parceiros sexuais sem os cuidados adequados para evitar a transmissão do HIV. 
Embora a origem africana seja a mais aceita atualmente, hipóteses diversas freqüentam o meio científico esporadicamente. Muito já foi dito, sem nenhuma shance de comprovação, sobre a possível fabricação do vírus em laboratório. Criou-se uma polêmica, também, quando foram levantadas questões sobre a utilização. de vacinas anti-poliomielite contaminadas.

Segundo alguns cientistas, lotes dessas vacinas teriam sido fabricadas a partir de células de rins de macaco que estariam contaminadas por um vírus semelhante ao HIV-1 e que também teria ação no sistema imunitário. Esta vacina foi testada no Zaire e em Burundi no final da década de 1950 e amplamente utilizada no continente africano ${ }^{24}$. Esta suspeita é fortalecida pelo fato do agente da imunodeficiência símia (SIV) ser patogênico apenas para certas espécies de macacos. Desta forma poderiam ter sido utilizadas, na inativação do vírus da poliomielite, células renais de macacos sadios, porém portadores do $\mathrm{SIV}^{50}$.

Outro fato levantado recentemente, como uma tentativa de explicar a origem do HIV foi o uso que se fez da vacina anti-polio como tratamento nos casos de herpes recorrente. Na década de setenta, esta utilização da vacina foi bastante divulgada nos EUA, sendo que grande parte dos indivíduos afetados pelo herpes era homossexual. Este fato e a evidente possibilidade de alguns lotes estarem realmente contaminados pelo SIV pode, através de possíveis mutações do vírus, explicar o início da epidemia que incidia predominantemente entre indivíduos homossexuais ${ }^{50}$.

Ainda sobre a hipótese causal da AIDS, uma polêmica persiste no meio científico. Iniciada em 1987 por Peter Duesberg, da Universidade de Berkeley, Califórnia, coloca em questão o papel do HIV na etiologia da AIDS. Esta questão motivou um encontro, realizado em Amsterdã, em maio de 1992, que reuniu várias autoridades em pesquisa sobre AIDS. Segundo Duesberg, quem primeiro levantou a questão, o HIV não seria o agente da síndrome, mas apenas um entre 
vários co-fatores que agiriam na determinação do quadro de AIDS. Desta forma, para se desencadear a doença haveria a necessidade de outros fatores, como por exemplo o micoplasma, uma bactéria comum em mucosa oral e genital.

Esta idéia de que o HIV é apenas uma causa necessária é hoje aceita por muitos pesquisadores ${ }^{43,88}$. Desta forma acredita-se que, na presença de certas características, principalmente certas infecçōes, haveria um estímulo para a expressão

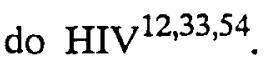

Esta pode ser, também, a explicação para o fato de algumas pessoas contaminadas desenvolverem doença em período muito curto de tempo, enquanto outras permanecem anos como portadores.

LIFSON e colaboradores ${ }^{54}$ (1988) citam estudos onde foi comprovado que infecções como a citomegalovirose ou o herpes, aumentaram a replicação do HIV. Co-fatores comportamentais também têm influência e acredita-se que a utilização de drogas alucinógenas assim como reinfecções, que aumentariam a quantidade de HIV no organismo, ou outras doenças sexualmente transmissíveis, podem facilitar a progressão do quadro de infecção para o de doença ${ }^{43,54}$.

Após o isolamento do HIV e da relação etiológica deste com a AIDS, o número de pesquisas sobre outros fatores que poderiam influir na etiologia da síndrome, diminuiu, como acontece com freqüência em pesquisas causais. $\hat{E}$ fato conhecido que, uma vez isolado um fator causal importante, os demais fatores deixam de ser pesquisados.

Ainda que, atualmente, alguns aspectos da AIDS constituam um enigma, muito se sabe sobre a patogenia do HIV. Nesses dez anos de epidemia algumas áreas da ciência, como a microbiologia, a farmacologia e a imunologia, foram bastante impulsionadas a se desenvolver e grande parte desses novos conhecimentos só ocorreram direta ou indiretamente, devido à epidemia de AIDS. 


\section{5 - CARACTERÍSTICAS EPIDEMIOLÓGICAS}

Como já foi descrito, aos primeiros casos de AIDS que foram identificados nos EUA, seguiram-se muitos outros em países da Europa, da África, da América Latina e, mais recentemente, da Ásia.

Em pouco tempo as autoridades sanitárias internacionais foram notificadas sobre casos da síndrome em muitos locais, tendo sido reconhecido, atualmente, casos de AIDS em 152 países ${ }^{13,74,77}$.

Estima-se que, do início da epidemia aos dias atuais, entre 9 e 11 milhöes de adultos e 1 milhão de crianças tenham se infectado no mundo ${ }^{76}$.

No Brasil, o primeiro caso autóctone foi identificado em $1982^{2}$, sendo que, após a introdução dos testes de detecção de anticorpos, em 1985, pelo menos um caso anterior, ocorrido em 1980 , pôde ser confirmado 5 .

O número de casos acumulados notificados no Brasil, até o início de outubro de 1992, era de 31466, com um coeficiente de incidência acumulada de 23,7 por 100000 habitantes. Grande parte destes casos (59,5\% dos casos acumulados de 1980-1992) se concentram no Estado de São Paulo, sendo que entre estes, $36,7 \%$ no Município de São Paulo ${ }^{67}$.

Em anos recentes, o padrão da epidemia, típica de grandes centros urbanos, mudou com o aumento do número de casos em cidades do interior do Estado de São Paulo. Este aumento ocorreu em decorrência de características próprias destas áreas, como o elevado consumo de drogas intravenosas e, em Santos, por fatores sociais reconhecidamente ligados às cidades portuárias como prostituiçāo e consumo de drogas. 
O Ministério da Saúde aponta as cidades com maiores coeficientes de incidência acumulada da doença no Brasil: Santos (217,1 casos por 100000 habitantes), São Paulo (116,7 por 100000 habitantes), São José do Rio Preto (116,2 por 100000 habitantes), São Vicente (110,9 por 100000 habitantes) e Ribeirão Preto (100,7 casos para cada 100000 habitantes). Todos são municípios do Estado de São Paulo ${ }^{67}$.

A alta incidência de casos na área de Santos, São Vicente e Guarujá, cidades litorâneas do Estado de São Paulo, pode ser explicada pelo bom nível dos programas de saúde desenvolvidos nesse local, nos últimos anos. Esses programas permitiram detectar grande parte dos casos incidentes, aumentaram a confiança da população nos serviços de saúde pública e tornaram a procura desses serviços um ato voluntário da população.

A epidemia foi, desde seu início em nosso meio, mais prevalente no sexo masculino do que no feminino, numa razão de 42:1, em 1985. Em 1991, esta relação foi bem menor, tendo sido notificados 5 casos masculinos para cada caso de AIDS no sexo feminino ${ }^{91}$. A diminuição da relação masculino-feminino deve-se ao aumento do número de casos de transmissão heterossexual ou por drogas intravenosas que, no início da epidemia, não ocorriam em nosso meio ${ }^{89}$.

A AIDS incide, predominantemente, em indivíduos adultos jovens, porém, a partir de 1985, passou a existir um crescente número de casos em menores de 15 anos. A faixa etária mais acometida, do início da epidemia até os dias atuais, é a de 20 a 49 anos com uma porcentagem de $85,6 \%$ do total de casos.

O aumento da transmissão por uso de drogas intravenosas alterou o perfil epidemiológico da doença a partir de 1987, quando era constituído, em sua maioria, por indivíduos do sexo masculino, adultos jovens e homossexuais. $O$ aparecimento de casos de AIDS em adolescentes e mesmo em menores de 15 anos fez com que diminuísse a faixa etária de maior incidência da doença. 
O aumento do número de casos do sexo feminino, quer por transmissão sexual quer por uso de drogas intravenosas, favorece a ocorrência de transmissão perinatal, fato que também contribui para a diminuição da faixa etária dos indivíduos acometidos.

No Brasil, a maior parte dos casos deve-se à transmissão sexual - seja ela homossexual ou bissexual- ou por uso de drogas intravenosas. No início da epidemia, o maior número de casos, $68,6 \%$, era devido ao contato sexual, enquanto apenas $3 \%$ era por uso de drogas. A partir de 1987 , este quadro foi se alterando sendo que, até o início de outubro de $1992,33.9 \%$ dos casos foram devidos a transmissão homossexual/bissexual e $24,9 \%$, por uso de drogas ${ }^{67}$.

A epidemia de AIDS trouxe a discussão características importantes da sociedade contemporânea como o comportamento sexual, a prática do uso de drogas, as dificuldades de se incorporar medidas de prevenção, além de mostrar, claramente, como a sociedade se coloca frente a esses tipos de comportamento.

Na área da saúde, além de todo um clima criado por mais uma doença estigmatizante, como já foram consideradas a hanseniase e também a sífilis, criou-se, ainda, uma série de problemas a serem enfrentados por todos da área.

O número crescente de leitos a serem ocupados pelos doentes de AIDS, que em geral necessitam internaçōes freqüentes, tornou-se um problema para os que fazem o planejamento de saúde das grandes cidades.

A possibilidade de adquirir a infeç̧ão é um risco a que uma parte da população se encontra exposta. O fato da AIDS apresentar uma alta letalidade e como, até o momento, os tratamentos conhecidos são de eficácia parcial, o medo da infecção torna-se um problema e este só pode ser enfrentado através da prevenção. Essa possibilidade de infecção se transforma em pânico para muitos, sob o respaldo das ineficientes e aterrorizadoras campanhas veiculadas em nosso país. 
Além dos problemas emergentes e práticos, como uma maior necessidade de leitos hospitalares, dificuldade em se fazer cumprir regras mínimas de segurança para profissionais da saúde, além das medidas de controle que se chocam com determinaçōes culturais, o elevado custo social da epidemia torna seu controle. uma medida prioritária. A morte de indivíduos, em geral jovens, custa à sociedade alguns anos de trabalho e altera seus indicadores demográticos de forma negativa com, por exemplo, a diminuição da esperança de vida da população ${ }^{34}$.

A importância da AIDS pode ser avaliada pelo fato desta constituir uma das maiores causas de morbiclade e de mortalidade nos EUA, onde foi a décima quinta causa de morte, em 1988 e onde passa a ser a principal causa de morte quando se consideram os anos potenciais de vida perdidos ${ }^{14,29}$. Na França, em relação a este indicador, as mortes por tumores, acidentes e suicídios, diminuíram de 1987 a 1990, enquanto que os anos potenciais de vida perdidos devido à AIDS aumentaram no mesmo período ${ }^{34}$.

No Município de São Paulo a AIDS foi a quarta causa de morte segundo o indicador anos potenciais de vida perdidos, no periodo de julho de 1991 a julho de 1992, estando à frente dos acidentes de trânsito e do infarto do miocárdio ${ }^{83}$. Em relação ao total de óbitos ocorridos nesse Município, de janeiro a março de 1992, a AIDS representa $4,3 \%$ do total dos óbitos ${ }^{84}$.

Outro fator que indica a crescente importancia desta doença nos EUA é que a inlecção pelo HIV, como causa básica de óbito, estava presente em 52\% dos atestados de óbito de pessoas da laixa etária de 25 a 44 anos, em 1986. No ano seguinte esta causa esteve indicada em $90 \%$ dás declarações de óbito dos individuos que faleceram com idade entre 25 e 44 anos $^{14}$.

Já cm 1984, na cidade de Nova York, a Síndrome de Imunodeficiência Adquirida foi a principal causa de morte entre individuos do sexo masculino da faixa etária de 30 a 39 anos, e uma das cinco primciras causas de óbito quando 
se considera a população masculina de 24 a 54 anos de idade, segundo KRISTAL ${ }^{49 .}$.

Em Uganda calcula-se que haja um milhão de pessoas infectadas, o que constitui $11 \%$ da populaçāo adulta. Estima-se que, em 2015, esse país deverá ter 22 milhões de habitantes dos quais um terço estarão infectados, desde que sejam mantidas as atuais características da doença ${ }^{1}$.

A epidemia que atingia preferencialmente individuos em idade produtiva torna-se mais ampla, atingindo crianças, filhos de pais portadores do vírus. Esta disseminação do agente etiológico agrava os problemas sociais, pois, além de doentes, ainda que o HIV não se transmita a todos os descendentes, estas crianças também se tornarão órfāos precocemente. Em muitos países este é mais um problema a ser enfirentado.

Além do grande problema do aumento do número de casos aliado à escassez de rccursos, há também a epidemia de infectados. O CDC projeta uma incidencia de 0,4 a $0,6 \%$ de portadores do HIV na população dos EUA ${ }^{35}$. No Brasil, estima-se que haja, aproximadamente, 750000 pessoas infectadas, o que é considerado como estimativa conservadora, segundo a Organização Panamericana da Saúde ${ }^{76}$.

O número de individuos infectados, que cresec constantemente, adicionado ao longo periodo de latência do vírus traduz um dos maiores problemas de saúde coletiva. A necessidade de interromper a transmissão do agente, as dificuldades de se conhecer quem está infectado e a escassa disponibilidade de recursos hospitalares fazem da AIDS um problema de saúde pública.

Concorre, tambèm, para aumentar a importancia da doença como questāo fundamental para a saúde da população, o aumento do número de casos em crianças, devido principalmente à incidência crescente de AIDS em mulheres e conseqüente aumento de transmissão vertical. 
As implicações econômicas da epidemia de AIDS não se limitam aos custos sociais como a perda de mäo de obra, o aumento do número de crianças abandonadas ou ortãos, mas se referem, também, ao custo direto das campanhas de prevenção e da adequada atenção à saúde para esses pacientes.

Os dados sobre o custo da epidemia variam nos diversos países. Segundo $\operatorname{ANKRAH}^{4}(1989)$, nesta época o Zaire gastava US\$ 816 por caso, a Tanzânia US\$ 367 enquanto o Brasil estimava que este gasto seria em torno de US\$21000 e o México US\$7345. Estes dados podem ter mudado, pois alguns itens tornaram-se mais acessíveis, porém os medicamentos de última linha sempre são extremamente caros e onerosos aos serviços públicos.

Os EUA gastaram, em 1985, aproximadamente US\$ 450000 com o tratamento de dez pacientes, o que é mais do que o orçamento de qualquer hospital do Zaire, onde $25 \%$ dos pacientes atendidos são HIV positivos ${ }^{85}$.

Ainda que os países desenvolvidos ajudem aos demais, financiando grande parte da assistência médica, estudos realizados pela Universidade de Harvard, EUA, sugerem que em vários países africanos o custo social das perdas devido à AIDS ultrapassa o total de ajuda financeira oferecido pelos países desenvolvidos ${ }^{4}$.

\section{6 - AS FONTES DE INFORMAÇÃO DE CASOS DE AIDS}

As principais lontes de informação sobre casos de AIDS se restringem ao Sistema de Vigilância Epidemiológica e aos atestados de óbito. 


\section{1 - A VIGILÂNCIA EIIDEMIOLÓGICA}

A principal fonte de informação de casos de AIDS, assim como de outras doenças infecciosas de notificação compulsória, é o Sistema de Vigilância Epidemiológica (SVE).

A vigilância é necessária para monitorar tendências temporais na ocorrência das doenças, detectar novos padrōes ou mudanças nas características dos pacientes e assistir ao desenvolvimento e avaliaçāo das medidas de prevençāo e controle da $\operatorname{doença~}^{47,96}$.

Este sistema permile a obtenção de dados de incidência de determinadas doenças, de maneira ágil e rápida, visando o planejamento antecipado de ações de saúde como a prevenção de epidemias e o controle das doenças por meio da avaliação das medidas preventivas.

No caso específico da AIDS, uma doença desconhecida até o início da década de oitenta, a vigilância epidemiológica pode fornecer, ainda, dados importantes para a projeção da epidemia e para o conhecimento das características clínicas e epidemiológicas da infecção pelo HIV.

O Sistema de Vigilância de AIDS dos EUA, que começou em 1981, após o reconhecimento dos primeiros casos da síndrome, contem hoje o maior número de casos de AIDS do mundo ${ }^{25}$. Nesse país um número significativo de estados fazem também a notiticação de portadores do HIV.

As vantagens de un sistema de notilicação saio evidentes, como permitir o conhecimento do curso da epidemia, permitir intervençōes rápidas e eficazes no controle da doença, entre outras coisas, porém existem muitos fatores que contribuem para que esta notificação não scja completa. 
Uma das principais dificuldades em se notificar os casos da doença é a definição de caso de AIDS para a vigilância epidemiológica, que foi proposta pelo CDC.

\subsection{1 - A defïnição de caso de AIDS}

As várias maneiras de manifestação da síndrome, de quadros de alterações constitucionais a manifestações neurológicas, tornaram necessário uma definição do que se entende por caso de AIDS.

Desta forma, em 1982 o CDC definiu, para fïns de vigilância epidemiológica, o que seria considerado caso de AIDS $^{16}$. A primeira definição de caso de AIDS referia se à qualquer doença moderadamente indicativa de deficiência de imunidade celular, como SK, PPC, criptococose e candidíase e infecçōes por outros agentes, onde houvessem sido afastadas todas as demais possíveis causas de imunodeficiência $^{70}$.

Esta definição foi revista c ampliada em junho de 1985, quando outras patologias até então não consideradas como relacionadas à AIDS foram acrescentadas à lista c, também, considerado o resultado de teste positivo, uma vez que este já estava disponivel. Esta nova definição, mais abrangente, levou a aumentar de 3 a $4 \%$ a proporção de casos novos notificados ${ }^{22}$.

Em 1987, o CDC lez uma nova revisão onde incluía um número maior de patologias, inclusive a demência causada pelo HIV e a síndrome da perda de peso (wasting syndrome) o que foi responsável pelo aumento de 19 a $24 \%$ no número de casos 92 .

No momento em que este trabalho estava sendo impresso, no final de 
dezembro de 1992, o CDC publicou uma nova revisāo do sistema de classificaçāo para a infecção pelo HIV e expandiu a definição de caso de AIDS de adultos e adolescentes, utilizada para fins de vigilância epidemiológica. Esta nova revisão acrescenta o critério de contagem de linfócitos $T$ (linfócitos $T$ auxiliadores ou células T4), células responsáveis por importantes funçōes na resposta imunológica. Além desse novo critério de contagem de células T4, acrescentou-se à lista de patologias relacionadas à AIDS, os casos clínicos de tuberculose pulmonar, pneumonia recorrente e câncer cervical invasivo. Com esta nova definição de caso que passou a vigorar, nos EUA, a partir de $1^{\text {o }}$ de janeiro de 1993 , estima-se que haja um aumento de $75 \%$ no número de casos' notificados ${ }^{20}$.

Além da definiçāo de caso, criou-se também um critério de classificaçāo da infecção que permite estabelecer a evolução clínica do processo, desde a infecção até o início da doença. A detinição do CDC, utilizada neste trabalho. assim como a classificação de estadiamento clínico, são apresentadas nos anexos 1 e 2 , respectivamente.

Devido às características próprias das manilestaçōes da infecção em crianças, foi estabelecida, para esse grupo de menores de 1.3 anos, uma classificaçāo específica.

À medida que se identilicavam os novos tipos de transmissāo, além do contato homossexual. è à medida que a doença ia se propagando, loi possivel conhecer melhor todas as formas de manilestaçōes da deliciência de imunidade gerada pela infecção. Por isso as revisōes da classificação e da definição de caso de AIDS constituem importante fator para as estatísticas, tanto do ponto de vista da vigilância epidemiológica como para os dados de mortalidade. No entanto o uso dessas definições em países com menos recursos cconômicos apresenta vários obstácules, principalmente, pela dificuldade de acesso e utilização dos testes diagnósticos.

É sabido que para vários países da África, alguns da América Latina e também da Ásia, é dilícil comprovar, através de exames laboratoriais, grande parte 
dos agentes de infecções oportunistas. Em muitos desses locais, os diagnósticos, tanto da síndrome quanto das infecçōes oportunistas, são diagnósticos clínicos.

O elevado custo dos exames subsidiários, como cultura de material para. identificar crescimento dos agentes, biópsias e mesmo testes confirmatórios, como o Western Blot, limitam a especificidade dos diagnósticos. Contribuem ainda, como obstáculos para se garantir a precisäo de um diagnóstico, as dificuldades de ordem técnica na realização dos testes e na leitura dos mesmos.

Na tentativa de contornar estas dificuldades foram criadas outras definiçōes que atendessem às necessidades e possibilidades de cada área. Assim, a Organização Mundial da Saúde (OMS) aceita, para os países da África, uma definiçāo de caso de AIDS eminentemente clínica, na impossibilidade de comprovação laboratorial ${ }^{70,75}$.

Os países da América Latina também se organizaram e lançaram uma nova definição de caso de AIDS em adulto onde, apesar da necessidade de um resultado positivo para o teste anti-HIV, as doenças são ordenadas segundo seu valor preditivo de gravidade da doença. Esta definição foi aceita. com pequenas modificaçōes, pelo Ministério da Saúde e proposta em 1989, tendo sido adotada a partir de $1^{\circ}$ de setembro de 1992, como definição complementar à do CDC. vigente na epocal ${ }^{6+, 68}$ (Ancxo 3).

\subsection{2 - Os problemas da subnotificação de casos}

Apesar dos esforços para se contornar as dificuldades inerentes à definição de caso de AIDS, uma quantidade grande de casos deixam de ser notificados e este fato ocorre em todos os países, independente de seu grau de desenvolvimento. Esse sub-registro pode ser qualitativo e quantitativo. 
Em estudo sobre a validade do sistema de vigilância epidemiológica de South Carolina, EUA, CONWAY e colaboradores ${ }^{26}$ (1989) identificaram 1513 prontuários hospitalares cuja alta se deu por doenças relacionadas à AIDS ou à infecção pelo HIV e os compararam com o sistema de notificação. Esta revisão permitiu a identificação de 153 casos que obedeciam as definições de casos de AIDS, tanto a de 1985 como a de 1987. Destes 153, apenas 91 $(53,1 \%)$ haviam sido notificados como casos de AIDS ao serviço de vigilância epidemiológica.

O Centro Nacional de Pesquisas de Opinião dos EUA realizou, em 1988, uma pesquisa com a linalidade de identificar casos e óbitos por AIDS assim como mortes por homicídio. Através de uma amostra nacional de domicílios, foram realizadas entrevistas sobre conhecimento de mortes por homicídio ou por AIDS no último ano. Segundo LAUMANN e colaboradores ${ }^{51}$ (1989), entre os indivíduos que responderam às questões do estudo, os de estrato social mais alto identificaram mais casos de AIDS do que aqueles individuos de estrato social baixo. Esses casos identificados foram comparados com os dados da vigilância epidemiológica e foi verificado que um grande número não havia sido notificado e esta sub-notificaçāo era maior em relação aos casos reconhecidos pelo estrato social alto. No entanto, comparando com o conhecimento de casos de homicídio, pode-se observar o contrário, a classe mais baixa identificava um maior número de casos.

O principal motivo para a ocorrência de sub-registro diferencial por estrato social parece ser o tipo de atendimento médico. A chamada "classe média" de cor branca nos EUA, em geral é atendida por serviço médico privado que, embora deva notificar o caso, pode omití-lo. Já os individuos das camadas sociais inferiores, ao serem atendidos em hospitais públicos ou nos demais serviços públicos de saúde, como clínicas de pré-natal ou outras, quando são diagnosticados como casos de AIDS são notificados imediatamente. 
Pode-se citar, ainda, o fato, apontado pelos autores, que indivíduos de estratos sociais mais baixos sāo mais facilmente identificados pelo sistema por serem considerados como de risco para doenças de transmissão sexual ou aquelas doenças menos aceitas socialmente ${ }^{51}$.

O General Social Survey também salientou a diferença entre casos notificados na costa oeste e na leste dos EUA, em relação ao número muito pequeno de casos notificados em outras grandes cidades. Chicago, por exemplo, apresenta características comuns a outros centros urbanos e portanto deveria ter uma incidência de casos de AIDS muito maior do que a conhecida, no entanto as estatísticas apontam menor prevalência nessa área ${ }^{51}$.

Várias são as possíveis explicaçōes para este tipo de sub-registro: dificuldade de identificação ou de diagnóstico dos casos, principalmente em locais mais pobres ou onde a doença é menos prevalente. A complexidade da definição de caso de AIDS, que torna difícil sua interpretação, assim como o desconhecimento da obrigatoriedade desse tipo de prática ou de como, e em qual momento, fazê-la. Outro fator que parece desempenhar importante papel na sub-notificação de casos de AIDS é a recusa, de grande parte dos seguros de saúde, em pagar a hospitalização devido a certos tipos de doença onde se inclui a síndrome de imunodeficiência adquirida. Pode se apontar, ainda, uma tendência médica em não revelar o diagnóstico. certo grau de omissão, entre outros latores responsáveis pela subnotiticação, não apenas de AIDS, mas de todas as demais doenças do sistema de vigilância.

Os programas de vigilância epidemiológica, em geral, trabalham com uma estimativa de sub-registro. Alguns chegam a estimar que este sub-registro possa ser de 75 a 90\%, nos EUA, para as doenças infecciosas de notificação compulsória ${ }^{96}$.

Um estudo realizado em Vermont, EUA, citado por CONWAY e colaboradores $^{26}(1989)$, mensurou a subnotificação de várias doenças. Desta forma, através da comparaçāo de registros hospitalares com os dados de vigilância 
epidemiológica, definiu-se uma subnotificação de $14 \%$ para casos de coqueluche e $88 \%$ para casos de gonorréia (doenças de notificação obrigatória naquele país), sendo de $41 \%$ a taxa de sub-registro para o total das doenças infecciosas sujeitas ao sistema de vigilância epidemiológica.

Um fator importante a ser considerado é o período de tempo entre o diagnóstico e a notificação do caso às autoridades sanitárias. Como foi apontado por ANDERSON \& $\mathrm{MAY}^{3}$ (1988), o atraso médio na notificação nos países da Europa e dos EUA, aumenta à medida que a epidemia cresce e esta é a causa da aparente diminuição na incidência da AIDS nesses locais.

\section{2 - O ATESTAdo DE ÓbITO}

Outra fonte de informação sobre casos de AIDS é o registro de mortalidade. As estatísticas de mortalidade, baseadas na causa básica da morte, sempre serviram como fonte importante de informação sobre doenças.

A Declaraçāo de Óbito (DO) contem uma parte onde sāo anotados dados do falecido, como idade, data de nascimento, sexo, ocupação, filiação, entre outros, e uma outra parte onde são identilicadas as doenças que contribuíram para a morte assim como os dados do médico que atendeu o doente. Embora esta última parte seja denominada de "atestado de óbito", neste trabalho este termo e "declaração de óbito" foram utilizados como sinônimos.

A declaração de óbito, após seu registro em cartório. permite açōes de ordem jurídica como delinição de herdeiros, término dos direitos da pessoa, entre outras. Já a parte médica, com informações sobre as doenças que levaram o indivíduo à morte, é utilizada em saúde pública. 
O Modelo Internacional de Atestado Médico de Causas de Morte deve conter a causa básica da morte, cuja definição é internacional ${ }^{73}$ e que constitui o dado fundamental para a elaboração das estatísticas de mortalidade. $O$ documento com as informaçōes demográficas e com a parte médica deve ser assinado pelo médico que atendeu o caso ou pelo médico legista nos casos de morte violenta. Estes devem anotar, na parte específica, todos os fatores que contribuíram para o óbito assim como a doença, ou a afecção, que originou todas as alteraçōes subseqüentes.

A declaração de óbito (DO) permite obter algumas informações importantes do ponto de vista epidemiológico, além da causa de morte, como data de nascimento, local do óbito, protïssão, grau de escolaridade e as demais causas mencionadas que contribuíram para a morte.

O conhecimento das causas de morte é importante pois servirá como dado para eleger prioridades, programas de prevenção, alocaçũo de recursos entre outras açōes básicas de saúde. Os dados de morbidade, que seriam os ideais para cumprir os objetivos citados acima, são incompletos e parciais ${ }^{53}$.

Ainda que a DO seja um documento com finalidades bastante bem definidas e dele derivem informaçōes epidemiológicas importantes, algumas vezes ele não é adequadamente preenchido, principalmente em relaçāo à parte médica. Este erro, ao anotar a causa básica, assim como as demais causas que contribuíram para o óbito, leva a alteraçōes de signilïcativa importância nas estatística de mortalidade ${ }^{69}$.

\subsubsection{As regras para seleção da causa de morte}

Conhecendo as lalhas de preenchimento da parte médica do atestado de óbito, comum em muitos países, e com finalidade de se estabelecer critérios 
definidos, a OMS estipulou regras para a identificação da causa básica da morte ${ }^{73}$. Desta forma, ao se codificar um atestado cuja parte médica não foi adequadamente preenchido, pode-se, pelo uso de critérios específicos, chegar à verdadeira causa básica da morte, mesmo estando informada incorretamente no atestado de óbito.

As regras definidas como "Regras para a Seleção da Causa da Morte"73, de uso internacional, ainda que criadas com a finalidade de permitir a correta identificação da verdadeira causa básica da morte, muitas vezes não são adequadas à seleção da AIDS como causa básica.

Estas regras de seleção de causa de morte não prevêem casos onde uma doença infecciosa possa ser devido a outra. As regras permitem apenas algumas seqüências onde determinadas infecções são ocasionadas por outras afecções, porém não são incluídas nesse grupo grande parte das patologias que ocorrem com freqüência nos casos de AIDS. O fato de doenças infecciosas serem ocasionadas por outras infecçōes, na verdade, só pôde ser verificado, na clínica, após o aparecimento da Síndrome de Imunodeficiência Adquirida. Da mesma forma, a seqüência de uma doença qualquer favorecer a instalação de quadros malignos como Sarcoma de Kaposi ou Linfoma não-Hodgkin ć considerada como "sumamente improvável" pelas regras acima citadas 31,73 .

Após o aparecimento da AIDS, ficou evidente a necessidade de uma revisão nas regras de seleção e codificação de causas de morte para que se pudesse, através delas, identificar óbitos devido à AIDS quando esta não está informada em uma seqüência admitida como clinicamente correta. Estas alteraçōcs, porém, não podem ser fcitas no período de vigência de uma revisão da Classificação Internacional de Doenças, mas apenas quando se realiza uma nova revisão da CID, de acordo com as normas vigentes.

No entanto, no caso da AIDS, pelo inusitado da situação que favorecia a omissão, consciente e de acordo com as regras, de grande número de casos de 
AIDS, optou-se por critérios menos rigıdos aında que não definidos pela própria Classificação. Assim, em vários locais, em momentos não coincidentes, passou-se a aceitar que uma doença infecciosa, como, por exemplo, PPC, fosse devido à outra infecção (pelo HIV) quando esta seqüência era informada na declaração de óbito.

Esta estratégia e o fato acima mencionado, embora bastante importantes na monitorização da epidemia, constituem um problema pois não houve nenhuma determinação internacional, assim como não foi especificado o período de início da medida, o que dificulta a comparação dos dados.

A Classificação Internacional de Doenças utilizada para codificar as causas de morte não previa, em sua 9a revisão, de 1975, um código específico para a AIDS. Dessa maneira, logo após o aparecimento dessa síndrome e com sua caracterização como imunodeficiência adquirida passou-se a utilizar o código 279.1 , que inclui qualquer deficiência de imunidade celular ${ }^{70,73}$.

A utilização deste código foi proposta pelo CDC e, no início de 1983, o Boletim do Centro Brasileiro para a Classificação de Doenças ${ }^{22}$ publicou uma nota onde este código era sugerido para a codificação da nova síndrome.

Embora este seja um código aceito e utilizado em vários paises, nāo traduz, estatisticamente, toda a força da epidemia. Nesta mesma categoria se agrupam vários tipos de delïciências, embora menos freqüentes, como a deficiência de imunidade congênita, as auto-imunes, as decorrentes de terapias agressivas e também a AIDS.

Nos EUA, a partir de janciro de 1987, passou-se a utilizar uma classificaçāo específica para a AIDS c doenças a cla relacionadas. Esta classificação ${ }^{18}$ utiliza espaços existentes, ou seja, códigos sem doenças, no Capítulo I da CID-9a , capítulo este referente às doenças infecciosas e parasitárias, para codificar, especificamente. 
a AIDS. Em seguida o Canadá adotou a mesma classificação que, por fornecer códigos específicos para cada intercorrência originada pelo HIV, permite uma identificação melhor dos $\operatorname{casos}^{14,18,47}$.

As informaçōes sobre o óbito devem servir, também, para completar as informações de um sistema de vigilância epidemiológica, assim como para avaliar os esforços das ações de saúde, além de constituir uma das melhores fontes de informação para a área da saúde.

A legislação brasileira sobre a síndrome da Imunodeficiência Adquirida -SIDA/AIDS ${ }^{62}$ é clara quanto à importância de se comparar as informaçōes dos dois sistemas e do fluxo desses dados entre ambos.

\subsection{2 - Os problemas de omissão da verdadeira causa da morte}

Alguns pontos negativos podem alterar significativamente os dados fornecidos pelo sistema de informaçōes de mortalidade. Uma das maneiras mais freqüentes de alteração dos dados sobre mortalidade é a anotação incorreta ou a omissão de dados importantes sobre a causa da morte, na parte médica do atestado de óbito. Este fato tende a ocorrer com maior freqüencia quando a morte é ocasionada por doenças estigmatizadas, aquelas não socialmente aceitas. A omissão da verdadeira causa de morte leva ao sub-registro desta causa o que altera, significativamente, as estatísticas de mortalidade assim como a letalidade da doença.

Sendo a AIDS uma doença com conotação discriminatória, pode ser omitida na declaração do óbito. Esta omissão pode ocorrer tanto pela incapacidade de diagnóstico como por motivos de conivência com o doente ou pela vontade da família em não revelar a verdadeira causa da morte no atestado. 
Existe um respeito do médico pela vontade do paciente em não revelar seu estado, quer seja de portador do vírus quer seja de doente. Este sigilo é ético e deve ser observado, a não ser que este fato coloque em risco a saúde de outra pessoa ou que resulte em prejuizo para a população. Desta forma o médico deixa de notificar o caso por pedido do paciente, que quer manter sua imagem diante da sociedade. Deixa também de colocar a verdadeira causa básica da morte, a pedido da lamília, e assim altera as estatísticas de mortalidade, a letalidade da doença e prejudica todos as açōes de saúde que se fazem baseadas nesses dados.

A revisão dos atestados de óbito pode permitir uma avaliação dos casos onde a morte, causada pela Síndrome da Imunodeficiência Adquirida, foi mascarada por outras causas. Esta revisão pode, também, identificar casos que, por qualquer motivo, não tenham sido reconhecidos pelo sistema de vigilância, servindo, desta forma, para completar as informaçōes deste sistema.

$\mathrm{O}$ atestado, por ser um documento utilizado com linalidades legais, é mais manuseado do que a ficha de notificação compulsória e, em geral, apresenta um sub-registro em relação à AIDS maior que o sub-registro de casos, como apontou HESSOL e colaboradores ${ }^{44}(1992)$ que identificaram, em San Francisco, EUA, um sub-registro de $9 \% \mathrm{em}$ relação ao óbito e $0,7 \% \mathrm{em}$ relação aos casos.

No Município de São Paulo o Programa de Aprimoramento das Informaçōes de Mortalidade, PRO-AIM, criado em outubro de 1989. passou a investigar e completar as informaçōes dos atestados também nos casos onde havia suspeita de infecção pelo HIV. No ano de 1991, investigando 333 óbitos de indivíduos de 20 a 49 anos, dos quais receberam 159 respostas, esse serviço possibilitou a identificação de 37 atestados (23,7\% dos casos respondidos) cuja causa era AIDS e esta não havia sido mencionada na $\mathrm{DO}^{55}$.

O Centro de Vigilância Epidemiológica da Secretaria Estadual da Saúde de São Paulo investigou todos os 1238 óbitos por AIDS ocorridos em 1991 nesse 
Município, encontrando 299 óbitos sem notificação. Desses, 289 faziam menção à AIDS e outros 10 só puderam ser recuperados pelo PRO-AIM ${ }^{30}$.

O conhecimento das patologias que acometem os portadores do vírus, mencionadas no atestado, assim como outras causas que possam ter contribuído para a morte são dados úteis para o planejamento das necessidades na área da saúde. Através desses dados podem ser planejadas as necessidades referentes a atenção médica, tipo de terapêutica, etc.

Uma revisão destes atestados, com finalidade de identificar óbitos devido à AIDS, pode permitir, não apenas a correção do sub-registro de casos, como também dos dados de mortalidade, fundamentais para grande parte das açôes de prevenção da cpidemia.

A revisāo dos atestados e a comparação das informaçōes de óbitos por AIDS com os casos notilicados permite que o sistema de vigilância epidemiológica seja completado, assim como possibilita conhecer algumas causas de subnotificaçāo.

Esta metodologia tem sido empregada em vários países com a finalidade de quantificar a cobertura da notificação e completá-la $\$ 1,+2,+7,59,60$.

Ainda que hoje o sistema de registro de óbito do Município de São Paulo funcione de forma cada vez mais eficaz e dinâmica, pois se coletam informações adicionais para os casos onde as existentes são insulicientes, isto não acontecia do início da epidemia.

Muitos óbitos devido à AIDS foram imputados a infecçōes oportunistas ou a outras doenças mencionadas na DO. Estes casos só poderāo ser identificados pela busca ativa, pela revisão manual de cada declaração de morte, uma vez que a AIDS, ou outra doença relacionada a cla, pode estar anotada e nāo ter sido considerada como a causa básica. 
Uma revisão de todos os atestados de óbito do Estado de São Paulo com a finalidade de definir o perfil da epidemia, com a complementação dos dados através de uma investigação posterior, se traduz como um trabalho extremamente oportuno, pois permitiria caracterizar a epidemia em seu início. A utilização dos óbitos de indivíduos do sexo masculino, de 20 a 49 anos, ocorridos no Município de São Paulo, permite uma idéia real dos casos pois, conforme comentado anteriormente, é no sexo masculino e nessa faixa etária que a epidemia se manifestou, no início, em diversos países. Isso possibilita assim, uma avaliação da tendência dos primeiros anos da epidemia em nosso meio. 
OBJETIVOS 


\section{OBJETIVOS}

\section{GERAL}

- Analisar a mortalidade pela Síndrome da imunodeficiência adquirida como meio de conhecer a tendência dessa epidemia no Município de São Paulo, de 1983 a 1986, scgundo algumas variáveis epidemiológicas.

\section{ESPECÍFICOS}

- Identificar as doenças que aparecem como causa de morte de individuos com AIDS.

- Identilicar as demais doenças citadas com mais freqüencia em atestados de óbito ocorridos por AIDS. 
MATERIAL E MÉTODOS 


\section{MATERIAL E MÉTODOS}

Foram revisadas as declaraçōes de óbito de indivíduos do sexo masculino, de 20 a 49 anos de idade, registradas no Município de São Paulo, de 1983 a 1986.

Definiu-se o período nesses quatro anos por constituir a fase inicial da epidemia que, acredita-se, possuía características especiais. Assim. o ano de 1983 define o início do conhecimento de casos da doença em nosso país, uma vez que o primeiro caso descrito como tendo adquirido a doença no Brasil foi diagnosticado em São Paulo no segundo semestre de $1982^{2}$.

Os anos de 1984, 1985 e 1986 foram caracterizados pelo interesse crescente, tanto da classe médica como da população, pela nova doença, o que possibilitou uma atenção maior dos clínicos e. conseqüentemente, um número maior de diagnósticos.

Desses quatro anos estudados, pôde-se recupcrar as informações de todos os meses com exceção de abril de 1985. Infelizmente, na tentativa de se obter uma melhor forma de armazenar os dados, alguns atestados de óbito foram misturados a outro tipo de documento de forma que tornou-se impossivel identificá-los. Ainda após algum tempo foi fcita uma nova tentativa de recuperação desses atestados no local 
em que estavam arquivados, porém sem resultado.

Segundo o Ministério da Saúde (Min.S.) ${ }^{67}$, no período de 1980 a 1982 ocorreram no País 8 casos de AIDS. Estes casos foram diagnosticados em indivíduos adultos jovens, do sexo masculino, sendo um em 1980 e 7 em 1982.

Esses oito casos, provavelmente, não foram os primeiros. É possivel que antes de 1980 alguns casos de AIDS tenham ocorrido sem, no entanto, terem sido diagnosticados como tal. Mesmo no início da epidemia, depois da divulgação da existência desta nova doença, a baixa incidência de casos pode ter tido por motivo a não identificação de alguns deles.

A revisão dos atestados de óbito desse periodo inicial dificilmente levaria a novos conhecimentos. Essa revisão envolveria grande númcro de atestados de óbito para a obtenção de alguns prováveis casos sem possibilidade de confirmação.

Como era de se esperar, a introdução da doença no Brasil ocorreu a princípio nas grandes cidades como São Paulo e Rio de Janciro, trazida do exterior por indivíduos do estrato sócio-econômico médio alto. Esses oito primeiros casos foram todos diagnosticados em São Paulo.

Desta forma, estudar o conjunto dos óbitos de indivíduos do sexo masculino, na faixa de 20 a 49 anos, ocorridos na cidade de São Paulo, ainda que a partir de 1983, permitc uma visão da história da epidemia no país.

Em muitos casos do ano de 1983, um grande esforço loi necessário para se decifrar o que estava anotado na parte médica do atestado de óbito, e este problema seria maior para os anos anteriores. Aliado a esse fato, acresce-se a dificuldade de leitura de grande parte desses atestados, cujas letras já estavam bastante apagadas por ação do tempo, principalmente naqueles arquivados pela segunda via. 
O MIN. S. apresenta as estatísticas de casos de AIDS, segundo a idade, fazendo uma divisão entre menores e maiores de 15 anos. Segundo o Boletim Epidemiológico do MIN. S., no período de 1980 a 1986, ocorreram no Brasil 58 casos de AIDS em menores de 15 anos $^{67}$.

Ainda que a mortalidade por doenças infecciosas em crianças seja elevada e pode mascarar casos de AIDS, nesse período, na faixa etária entre 15 e 19 anos, assim como em menores de 15 anos, a freqüência da doença era baixa e por isso optou-se por selecionar apenas atestados de individuos que faleceram entre 20 e 49 anos de idade.

A determinação de estudar a faixa etária de 20 a 49 anos foi baseada na elevada incidência de casos desta síndrome em adultos jovens, fato observado no início da epidemia, em outros locais, onde o padrão de transmissão era por contato homossexual e por uso de drogas intravenosas ${ }^{14,42,60}$.

Incluiram-se apenas os óbitos de indivíduos do sexo masculino pelo fato das estatísticas indicarem poucos casos de AIDS no sexo feminino, nesse período.

Foram identificados 23 casos de AIDS em mulheres com mais de 15 anos, no Estado de Såo Paulo, até o ano de $1986^{90}$. O grande aumento de incidência dessa síndrome no sexo feminino deu-se a partir de 1987 quando loram diagnosticados 116 casos novos.

A metodologia de revisão das DOs, uma a uma, foi também um importante fator na limitação tanto da faixa etária quanto do sexo. Apesar da existência de dados de mortalidade em fitas magnéticas, a utilização desta via não permitiria a identificação nominal do individuo e a posterior comparação com os dados de vigilância epidemiológicia.

A seleção dos atestados foi realizada em etapas. A primeira foi a separaçāo dos atestados de indivíduos do sexo masculino da faixa etária definida para o 
estudo. Estas declaraçōes, correspondentes aos anos de 1983 a 1986, sofreram nova seleção para a escolha da causa de morte a ser incluída no trabalho. Assim foram excluídas as mortes por acidentes (qualquer tipo), os homicídios e os óbitos ocasionados por doenças como infarto do miocárdio, câncer, e demais doenças bem definidas e que sabidamente não estão associadas à AIDS.

Entre as causas básicas de morte que foram excluídas do estudo encontra-se a hemofilia. Esse defeito da coagulação, embora tenha sido relacionado à AIDS no início da epidemia, não foi incluído no estudo. Isto porque, em primeiro lugar, foram notificados, no Estado de São Paulo. de 1980 a 1986, 20 casos de AIDS cujo modo de transmissão do vírus foi a transfusão de fatores de coagulação. Entre esses 20 casos notificados no período e referentes a todo o Estado de São Paulo. 13 foram casos de individuos com 15 ou mais anos de idade.

Além do número pequeno de casos notificados nesse periodo, em relaçāo aos demais tipos de transmissão, outro motivo que permitiu a exclusão dos óbitos por hemofilia foi o total de atestados sclecionados com exsa causa. Na revisĩo dos atestados para a seleçāo dos óbitos a serem incluídos no estudo foram identificados 6 óbitos devido à hemofilia no periodo de 1983 a 1986 . Entre esses seis óbitos, $\mathrm{cm}$ dois havia a mençāo de AIDS e eram notificados como caso de AIDS. Um dos atcrtados fazia menção de imunodeliciência e não era notificado. Os demais cram óbitos que, pelas inlormaçōes anotadas, de forma clara e consistente, não se relacionavan a síndrome. Um dases óbitos indicava um acidente vascular cercbral como causa terminal. outro mencionava um processo infeccioso de membro interior levando a septicemia e o terceiro mencionava uma seqüéncia de hemorragia digestiva alta levando à laparotomia exploradora e com uma septicemia como causa terminal. Todos esses não eram casos notificados de AIDS.

Cumpre esclarecer que, ainda que o número de casos de AIDS em hemofílicos, notilicado no período de 1983 a 1986. fosse pequeno e, possivelmente um pouco menor a morlalidade por essa causa, pode-se, a partir desses atestados 
levantar questões amplas sobre a transmissão da AIDS. Assim, pode-se discutir o papel do sangue contaminado, as regras de Seleção de causa básica da morte em vigor no período, entre outros aspectos de grande importância para o conhecimento da epidemia. Porém, ainda que admitamos a importância desses fatores, não constitui objeto deste estudo a análise do tipo de transmissão da AIDS.

Foram também excluídas as imunodeficiências adquiridas como causa básica de morte quando no atestado de óbito havia a menção das doenças que levaram, direta ou indiretamente à essa imunodeficiência. Assim foram excluídas, por exemplo, a sequeencia de determinadas doenças cujo tratamento leva à uma imunodeficiência adquirida, sem que haja relação com o HIV.

As mortes violentas, ocasionadas por acidentes ou por homicídios, foram excluídas porque, nessa faixa etária, estas são causas de morte que ocorrem com bastante freqüência e portanto, teriamos um aumento no número de atestados estudados sem, no entanto, corresponder a igual aumento na probabilidade desses óbitos significarem casos de AIDS. Alguns estudos relacionando o aumento do número de mortes por suicídio têm sido publicados e por este motivo esta causa de morte foi incluida nesse trabalho.

A definição de causa básica de morte utilizada para selecionar as DOs. assim como as regras de seleção desta causa constam da CID, 9a revisāo, de $1975^{73}$. A rigor essas regras nāo privilegiam a seleção da AIDS como causa básica, particularmente naqueles casos onde estāo declaradas as complicaçōes, mesmo as mais freqüentes, sem indicar o termo "AIDS" ou "síndrome de imunodeficiência adquirida".

Como critério de inclusão das causas de morte a serem consideradas neste estudo, usou-se como referência a definição de caso de AIDS publicada pelo CDC, em vigor até então, e que inclui as doenças mencionadas a seguir como indicadoras de possível infecção pelo HIV ${ }^{19}$. 
A definiçāo de caso de AIDS utilizada em nosso país é constituída, também, pelo critério do $\mathrm{CDC}$, com certas alterações que facilitam a determinação do diagnóstico da sindrome. As dificuldades inerentes ao sistema precário de saúde, como dificuldade em se conseguir diagnósticos laboratoriais e o padrão das endemias no pais, foram motivos que colaboraram para a elaboraçāo de um novo critério a ser utilizado com finalidades de vigilância epidemiológica ou seja, para se notificar um caso, ou óbito, por AIDS no Brasil ${ }^{68}$.

Esses critérios, estabelecidos em Reuniāo da Organizaçāo Panamericana da Saúde (OPS), em 1987, na Venezuela, tinham por linalidade permitir que a Vigilância Epidemiológica se fizesse com maior eliciência nos paises onde há dificuldade de se utilizar dados laboratoriais e onde as doenças infecciosas sāo muito prevalentes.

Foram também selecionados para este estudo óbitos ocorridos por algumas outras doenças infecciosas, como sarampo, varicela, enterites, infecçōes bacterianas, entre outras. Estas inclusões se justificam pela alta prevalência dessas infecçōes em nosso meio, e pelo fato que, um aumento na mortalidade ocasionada por essas doenças poderiam estar mascarando um aumento na freqüencia da infecção pelo HIV.

Considerou-se também, como critério de inclusāo, qualquer óbito ocorrido como devido a tuberculose, e não apenas a tuberculose disscminada como ná definição do CDC, vigente no período de coleta dos dados. Este critério, adotado desde o início do trabalho, mostrou-se adequado, pela alta prevalência de tuberculose em nosso meio e também pelo fato que, na atual deliniçāo do CDC para caso de $\operatorname{AIDS}^{20}$, este critério passou a ser adotado em relação à tuberculose.

Criou-se então um banco contendo os dados relativos aos óbitos devidos a AIDS, imunodeliciências, ou demais causas relacionadas à AIDS, listadas a seguir, consideradas presumiveis de serem conseqüentes à inlecção pelo HIV. 


\section{LISTA DAS DOENÇAS MENCIONADAS NOS ATESTADOS DE ÓBITO E QUE SERVIRAM PARA A SELEÇÃO DOS CASOS DO ESTUDO:}

A- Síndrome de Imunodeficiência Adquirida, AIDS, SIDA, deficiência de imunidade adquirida ou imunodeficiência sem outra especificação (em qualquer parte do atestado).

Foram excluídos os casos referentes à defïciência de imunidade conseqüente a hemofilia, transplante renal, doenças do colágeno ou demais entidades bem definidas cuja terapêtica leva à deliciência de imunidade (desde que houvesse essa informaçāo no atestado). Esta exclusāo se deve ao fato destas causas poucas vezes serem omitidas nas DOs e sua inclusão apenas aumentaria a quantidade de atestados revisados sem, no entanto, enriquecer a análise, como já foi citado.

B- As doenças relacionadas à AIDS, como as listadas abaixo:

- Aspergilose pulmonar:

- Criptococose :

- Infecção por citomegalovírus;

- Infecções por herpes simples;

- Linfoma nāo-Hodgkin:

- Linfoma de Burkitt;

- Micobacteriose atípica:

- Monilíasc:

- Pneumonia por Pneumocystis carinii ou pneumocistose;

- Sarcoma de Kaposi;

- Toxoplasmose :

- Tuberculose

e a menção de "infecção oportunista" 
Estas doenças com determinadas especificaçōes, como, por exemplo, tuberculose disseminada, esofagite por Cândida, pneumonia por Cândida, constituem o elenco de doenças que foram relacionadas à AIDS pelo CDC, em $1987^{70}$. No Brasil, embora o critério estabelecido tenha sido bascado no dos EUA, não há determinadas restriçōes ao tipo histológico ou órgão atingido pela infecção. Atualmente aceita-se, por exemplo, a tuberculose pulmonar ou apenas a menção de tuberculose, em indivíduos HIV positivos, como critério de caso de AIDS. (anexo 3).

C. Outras causas de morte selecionadas para o estudo

- Bacteremiat;

- Blastomicose;

- Broncopneumonia - quando esta era a causa básica ou a única causa anotada na parte médica do atestado;

- Desnutrição quando informada como causa básica;

- Doenças do pulmão (outras que não as especificadas);

- Donovanose:

- Enterite crônica;

- Enterocolite aguda:

- Gastroentcritc;

- Leucose linfóide aguda;

- Linfoma;

- Linfossarcoma;

- Meningoencefalite ;

- Meningite e outras doenças inflamatórias do Sistema Nervoso Central -SNC ;

- Paracoccidioidomicose;

- Pneumonia Lobar (devida à dificuldade de se diagnosticar Pneumocystis carinii cm nosso meio)

- Pncumopatia inlecciosa: 
- Pneumopatia intersticial ;

- Processo pneumônico ;

- Sarampo;

- Septicemia;

- Suicídio;

- Varicela

Optou-se por selecionar os óbitos devido a esse grupo de causas por serem processos infecciosos, micoses, ou câncer, que podem ocorrer como quadro terminal em casos de infecção pelo vírus da imunodeficiência adquirida. O suicídio foi selecionado por ocorrer com certa freqüência em indivíduos com certos tipos de doenças graves e também nos quadros clínicos de alteração do sistema nervoso, comum em várias doenças inclusive na AIDS.

Além dessas patologias foram revisados e incluídos no estudo alguns atestados de óbito cujas causas básicas não obedecem ao critério exposto. Assim, as seguintes afecções foram mencionadas, uma vez cada, como causa básica de morte e incluídas no estudo: abscesso cerebral, doença linfoproliferativa, estafilococia, pneumopatia infecciosa, pneumopatia intersticial, broncopneumonia e insuficiência cardíaca.

Alguns desses sete casos foram identificados por serem casos de AIDS notificados ao Serviço de Vigilância Epidemiológica (SVE), outros por informações fornecidas pelos serviços de saúde, alguns pela imprensa, ainda que não fossem casos notificados. Da mesma forma incluiu-se, também, os atestados de óbito de casos reconhecidamente identifïados como AIDS onde csta não era mencionada mas, sim, uma das seguintes patologias: carcinomatose, neoplasia do encéfalo, leucemia, abscesso intracraniano, edema pulmonar .

O fato de serem identificados atestados de óbito de indivíduos com AIDS onde a causa básica cra, como citado, edema pulmonar ou abscesso intracraniano, 
sugere uma investigação também nas declarações de morte onde estas, e talvez outras afecções, estejam mencionadas como causa básica. Porém esta proposta não se justifica neste trabalho pois levaria a selecionar todas as outras patologias como objeto de estudo.

Vale ressaltar que algumas vezes, durante o processo de revisão, certos atestados foram selecionados também pelas informaçōes anotadas, ainda que não relacionadas à Síndrome da Imunodeficiência Adquirida. Informaçōes como estado civil, ocupação, óbito hospitalar e a menção de uma causa indeterminada, assim como o nome do médico que assinou a declaração, indicavam casos "suspeitos". Em grande parte das vezes estes atestados resultaram ser casos notificados de AIDS, após a comparação com dados da vigilância epidemiológica.

A grande prevalência de doenças infecciosas em nosso meio e a dificuldade de se diagnosticar seus agentes etiológicos tornam dilícil a exclusão da imunodeficiência adquirida como facilitadora da instalação desses quadros. Assim, em muitos casos, apenas uma investigação maior, com consulta aos prontuários ou por entrevista com o médico, é que permitiria alirmar, ou excluir, a AIDS como causa básica.

Em resumo, lazem parte deste estudo óbitos de indivíduos do sexo masculino, de 20 a 49 anos de idade, que faleceram no Município de São Paulo, de 1983 a 1986, e que se enquadram em um dos seguintes grupos de causas de morte:
A) AIDS/SIDA ou imunodeficiência ;
B) Doenças relacionadas à AIDS;
C) Doenças que poderiam ser decorrentes da imunodeficiência adquirida pelo HIV (Virus da imunodeficiência Humana), ainda que não houvesse menção desta infecção no atestado de óbito.
D) outras doenças como causa da morte em casos reconhecidos como AIDS. 
Após a seleção dos casos que iriam compor o estudo, foi feita cópia xerográfica das declaraçôes de óbito. As cópias foram, então, numeradas e a seguir codificadas as variáveis que seriam estudadas.

Foram utilizadas as seguintes variáveis da Declaraçāo de Óbito: a- data do óbito (dia, mês e ano)

b- estado civil (solteiro, casado, viúvo, etc)

c- idade ao morrer (em anos completos)

d- local de ocorrência (hospital, domicilio, via pública, etc)

e- hospital de ocorrência (criou-se um código de três dígitos para identificar o hospital)

f- profissão (usou-se a Classificação Brasileira de Ocupaçōes para o Subsistema de Informaçōes sobre Mortalidade do Ministério da Saúde $)^{63}$

g- grau de instrução (nenhum, fundamental, $2_{-}^{\circ}$ grau, etc)

h- causa básica do óbito (CB) (codificada pela CID-9a-)

i- demais causas da parte médica do atestado de óbito, além da causa básica.

Os dados foram comparados com a listagem de casos notificados ao CVE, até abril de 1992. Esta lista contem o nome de todos os casos de AIDS do Estado de São Paulo, a data de nascimento, a data da notificação, a data de óbito e o fator de risco de transmissão. Essas informaçōes permitiram que se separassem os óbitos em quatro grupos, segundo a notificação, tanto do caso quanto do óbito :

1 - caso e óbito notificados: algumas vezes o caso é notificado pelo atestado de óbito devido à informação da causa básica.

2 - caso notificado e óbito não notificado;

3 - caso e óbito não notificados;

4 - não-caso de AIDS: óbitos que não puderam ser comprovados como decorrentes de infecçāo pelo HIV, constituindo o grupo de causas presumiveis. 
Os óbitos foram classificados em:

\section{A- óbitos onde havia menção de AIDS no atestado:}

1- AIDS ou imunodeficiência como causa básica da morte, sendo caso notificado;

2- AIDS ou imunodeficiência como causa básica da morte, sendo caso não notificado;

3- AIDS ou imunodeficiência citada na declaração de óbito, não como causa básica, porém referente a caso notificado;

4- AIDS ou imunodeficiência citada na declaração de óbito, não como causa básica e sem notificação do caso.

\section{B- óbitos sem menção de AIDS ou imunodeficiência:}

5- Doenças relacionadas à síndrome como causa básica do óbito, em casos notificados de AIDS;

6- Doenças relacionadas à síndrome como causa básica da morte, em casos não notilicados;

7- AIDS não mencionada e outras doenças como causa básica da morte em casos de AIDS notificados;

8- AIDS não mencionada no atestado e óbitos por outras causas ou doenças não relacionadas à AIDS, onde informaçôes adicionais permitiram identificí-los como casos da síndrome, em casos não notilicados;

9. Óbitos decorrentes de doenças incluídas no elenco de patologias selecionadas, consideradas como presumíveis de serem decorrentes da infecção pelo HIV, sem notificação.

A apresentação dos dados foi feita por tabelas de freqüência absoluta e relativa dos óbitos segundo as variáveis de interesse e, quando necessário, foi feito o teste de associação pelo $\mathrm{X}^{2}$ ou pelo Teste Exato de Fishèr, quando em qualquer casela houve valor esperado menor que 5. Além disso foi feito o teste de hipótese para as médias de duas populaçōes não correlatas com desvio padrão nāo conhecido porém supostamente iguais". 
RESULTADOS E DISCUSSÃO 


\section{RESULTADOS E DISCUSSÃO}

\section{1 - CARACTERIZAÇÃo DOS ÓBITOS ESTUDADOS}

Neste trabalho, são analisadas 4023 declarações referentes aos óbitos de indivíduos do sexo masculino, com idade entre 20 e 49 anos e que faleceram no Município de São Paulo, de 1983 a 1986, selecionadas por preencherem os requisitos deste estudo.

A tabela 1 mostra o número de atestados selecionados para o estudo, segundo ano de ocorrência. Pode-se verificar que há uma certa proporção, constante, com exceção do ano de 1986, de óbitos devido as causas selecionadas. Assim, para cada ano de estudo, houve entre $10 \%{ }^{\circ}$ e $11 \%$ de óbito desse grupo de causas, em relaçāo ao total dos óbitos dessa faixa etária, ocorridos no Município de São Paulo. 
TABELA 1 - Número de óbitos de individuos do sexo masculino, de 20 a 49 anos, segundo ano de ocorrência, Município de São Paulo, 1983-1986.

\begin{tabular}{lccccc}
\hline \multirow{2}{*}{ ANO } & \multicolumn{2}{c}{ DOs selecionadas } & & \multicolumn{2}{c}{ Total $^{(*)}$} \\
\cline { 2 - 3 } \cline { 5 - 6 } & No & \% & & No & \% \\
\hline 1983 & 891 & 10,7 & & 8302 & 100,0 \\
1984 & 957 & 10,5 & & 9129 & 100,0 \\
$1985^{(* *)}$ & 980 & 10,8 & & 9071 & 100,0 \\
1986 & 1195 & 12,1 & & 9842 & 100,0 \\
\hline TOTAL & 4023 & 11,1 & & 36344 & 100,0 \\
\hline
\end{tabular}

(*) Total de óbitos do sexo masculino, da faixa etária considerada, ocorridos no Município de São Paulo Fonte:Ministério da Saúde -Estatísticas de Mortalidade Brasil.

(") Não se incluem os óbitos ocorridos em abril de 1985.

\section{1 - Em relação ao estado civil}

Do total de óbitos, 50,2 \% correspondiam a indivíduos solteiros, $38,2 \%$ a casados, $3,8 \%$ a separados, desquitados, divorciados ou viúvos, $0,4 \%$ a outros tipos de união e em $7,4 \%$ dos casos a informação era ignorada.

\section{2 - Em relação ao local de Ocorrência :}

Dos 4023 óbitos estudados, $76,7 \%$ ocorreram em hospitais, $15,4 \%$ no domicílio, $3,8 \%$ em via pública, $3,9 \%$ em outros locais e $0,2 \%$ em local tido como ignorado.

Dentre os óbitos ocorridos em hospitais, 9,7\% aconteceram no Parque Hospitalar do Mandaqui, provavelmente pela maior demanda de casos de tuberculose nesse serviço médico. O Hospital das Clínicas da Faculdade de Medicina 
da USP aparece em segundo lugar com 6,4\% dos óbitos e o Hospital Emilio Ribas, por ser um serviço que atende especificamente doenças infecciosas, em terceiro lugar, com 5,2\% do total dos óbitos do estudo que ocorreram em hospitais.

Do total dos óbitos estudados, 2,8\% ocorreram na Santa Casa de Misericórdia de São Paulo, 2,7\% no Hospital Municipal do Tatuapé e no Hospital Municipal "Dr. Arthur Saboia Ribeiro", 2,6\%; os demais hospitais tiveram participação menor. Chama a atenção o número de casos onde esta informação é ignorada: 7,35\% dos casos tidos como ocorridos em hospitais não contem informações sobre estes.

\section{3 - Em relação à idade}

A distribuição da idade ao morrer é apresentada na tabela 2 . O coeficiente de mortalidade por faixa etária, calculado para o periodo de estudo, indica que a mortalidade por essas causas selecionadas cresce com a idade.

TABELA 2 - Número de óbitos e coeficiente de mortalidade segundo idade para as causas estudadas, em indivíduos do sexo masculino, de 20 a 49 anos, Município de São Paulo, de 1983 a 1986.

\begin{tabular}{lcc}
\hline IDADE(anos) & No & COEFICIENTE $^{\left({ }^{*}\right)}$ \\
\hline & & \\
$20-24$ & 413 & 2,2 \\
$25-29$ & 608 & 2,8 \\
$30-34$ & 776 & 4,2 \\
$35-39$ & 781 & 5,8 \\
$40-44$ & 736 & 7,3 \\
$45-49$ & 709 & 8,1 \\
& & 4,4 \\
\hline TOTAL & 4023 & \\
\hline
\end{tabular}

(*) Coeficiente por 10000 indivíduos do sexo masculino calculado utilizando a população de cada faixa etária, estimada para o meio do período, por interpolação (Lagrange). 


\section{4 - Em relação à ocupaçāo}

Aquelas atividades consideradas como trabalho braçal (não classificado de outra maneira pela Classificação Brasileira de Ocupações para o Subsistema de Informações sobre Mortalidade) apareceram mencionadas em 12,5\% dos atestados de óbito. Em 11,4\% os indivíduos eram inativos, aposentados ou inválidos, em 5,3\% foram declarados como pedreiros ou estucadores, em 4,4\% condutores de automóvel, ônibus, caminhōes e veículos similares e $2,8 \%$ eram vendedores do comércio.

A ocupação é um item freqüentemente não preenchido ou aparece como ignorada. Neste estudo, esse item foi assim classificado em $10 \%$ dos atestados.

\section{5 - Em relação ao grau de Instrução}

Em relação ao grau de instruçāo, nota-se também uma elevada frequiência de ignorados $(40,7 \%)$ sendo que em $3,8 \%$ a instrução era nenhuma, em $45,1 \%$ fundamental, em $5,5 \%$ os individuos tinham o segundo grau e em $4,9 \%$ o nivel superior.

1.6 - Em relação às causas de morte

Entre as causas de morte que faziam parte do elenco de patologias que serviu como critério de inclusão no estudo, chama a atenção o elevado número de pneumonias e broncopneumonias, citadas como causa básica em 39\% dos atestados e que constituem a causa básica mais freqüente, como mostra a tabela 3 . 
As mortes em função dessas duas causas, pneumonias e broncopneumonias, podem traduzir a falta de diagnóstico mais específico, o que causa surpresa principalmente por se tratar de óbitos ocorridos, em sua maioria, em hospitais, onde deveriam existir condiçōes de especificar melhor essas ocorrências.

A metodologia de revisão de DOs com a finalidade de detectar casos de AIDS, quer contribuindo para o conhecimento de casos que nāo haviam sido notificados, quer para avaliar a mortalidade dos casos conhecidos, foi empregada pela primeira vez em $1987^{41}$. Esse estudo, realizado em quatro cidades norte-americanas, revisou atestados de óbito ocorridos em um periodo de três meses, cuja causa básica fosse AIDS ou doenças relacionadas a esta síndrome. Nesse estudo foram, também, incluídas as mortes por pneumonia pois esta poderia ser uma manifestação da AIDS, ainda que não identificada ${ }^{95}$.

A ocorrência de pneumonia como manifestação da imunodeficiência adquirida é tāo importante que na mais recente revisão de definição de caso de AIDS, em vigor a partir de $1^{\circ}$ de janeiro de 1993 , um dos critérios incluidos foi a ocorrência de pneumonias recorrentes 20 .

Seguiram-se, em ordem decrescente de freqüência, o suicídio que foi a causa básica em $20,45 \%$ dos casos e a tuberculose, em $17,8 \%$. O suicídio é freqüentemente referido como causa de morte de individuos com determinadas doenças como por exemplo, doença renal crônica, câncer ou doenças mentais. Um estudo realizado sobre suicídio, em Nova York, em 1985, concluiu que o risco relativo de suicídio entre indivíduos com AIDS, de 20 a 59 anos, é 36,3 vezes maior em relação ao grupo de mesma idade, sem AIDS e 66,1 vezes maior que o risco de suicídio da população geral $^{57}$. 
TABELA 3 - Óbitos de indivíduos do sexo masculino, de 20 a 49 anos de idade, segundo a causa básica selecionada para o estudo, Município de São Paulo, de 1983 a 1986.

\begin{tabular}{|c|c|c|}
\hline Causas ( código CID-9 ${ }^{\circ}$ ) & No & $\%$ \\
\hline Pneumonias e Broncopneumonia $(480-486)$ & 1572 & 39,07 \\
\hline Suicídio (E950-E959) & 823 & 20,46 \\
\hline Tuberculoses $(010-018)$ & 716 & 17,80 \\
\hline Algumas doenças Inflam.SNC ${ }^{*}(320-323)$ & 214 & 5,32 \\
\hline Síndrome Imunodef.Adquirida (279.1) & 175 & 4,35 \\
\hline Linfossarcoma e Linfomas (200 e 202) & 142 & 3,52 \\
\hline Septicemia $(038.9)$ & 94 & 2,33 \\
\hline Enterites e gastroenterite $(003,009)$ & 44 & 1,10 \\
\hline Deficiências Nutricionais (260-269) & 40 & 1,00 \\
\hline Outras doenças do Pulmão (518) & 38 & 0,95 \\
\hline Outras doenças Infec. e Parasit.(136) & 24 & 0,60 \\
\hline Infecçāo blastomicótica (116) & 16 & 0,40 \\
\hline Outras Pneumopatias alveolares (516) & 13 & 0,32 \\
\hline Sarcoma de Kaposi (173.9) & 12 & 0,30 \\
\hline Criptococose (117.5) & 12 & 0,30 \\
\hline Abscesso Intracraniano ${ }^{*}(324.0)$ & 10 & 0,25 \\
\hline Varicela $(052)$ & 7 & 0,20 \\
\hline Trans. Equil. Hidroeletrolítico (276) & 7 & 0,20 \\
\hline Imunodeficiência (279.3) & 6 & 0,15 \\
\hline Toxoplasmose (130) & 6 & 0,15 \\
\hline Infecçāo bacteriana (041) & 5 & 0,12 \\
\hline Menigoencefalite (049.0) & 5 & 0,12 \\
\hline Efeito tardio de tuberculose (137) & 4 & 0,10 \\
\hline Sarampo $(055)$ & 3 & 0,07 \\
\hline Moniliase (112) & 3 & 0,07 \\
\hline Outros Tipos de Neoplasmas ${ }^{\text {". }}$ & 3 & 0,07 \\
\hline Citomegalovirose (078.5) & 2 & 0,05 \\
\hline Carcinomatose (199) & 2 & 0,05 \\
\hline Doença Linfoproliferativa (238.7) & 2 & 0,05 \\
\hline Meningococemia (036.2) & 1 & 0,02 \\
\hline Herpes simples (054) & 1 & 0,02 \\
\hline Conjuntivite viral (077.9) & 1 & 0,02 \\
\hline Infecçāo viral (079.9) & 1 & 0,02 \\
\hline Donovanose $(099.2)$ & 1 & 0,02 \\
\hline Neoplasma do Encéfalo (191) & 1 & 0,02 \\
\hline Leucemia $(205)^{\text {"* }}$ & 1 & 0,02 \\
\hline Edema Cerebral " & 1 & 0,02 \\
\hline Bacteremia (790.7) & 1 & 0,02 \\
\hline Demais causas selecionadas & 14 & 0,35 \\
\hline TOTAL & 4023 & 100.00 \\
\hline
\end{tabular}

* SNC = Sistema Nervoso Central

" causas selecionadas apenas porque se sabia serem caso de AIDS 
A tuberculose, doença bastante prevalente em nosso país, tem apresentado um aumento de incidência nos países do primeiro mundo. Este aumento de número de casos coincide com o início da epidemia de AIDS e, segundo estimativas da OMS, aproximadamente 4 milhões de pessoas no mundo estariam infectadas por ambos, pelo Mycobacterium tuberculosis e pelo HIV, no início de $1992^{72}$. Ainda que esta seja uma estimativa do número de indivíduos infectados, é sabido que o risco de desenvolver tuberculose doença é maior em indivíduos portadores do vírus da imunodeficiência adquirida.

Entre os casos aqui analisados, chama a atenção a freqüência de algumas patologias que raramente são mencionadas como causa básica de morte. Uma dessas patologias é a enterite que é poucas vezes causa de óbito de indivíduos na faixa etária de 20 a 49 anos. Além desta, chamam a atenção, também, quando referidas como causa básica, a monilíase e herpes simples, entre outras. Estas infecções, antes do aparecimento da AIDS, ocorriam de forma secundária a um outro quadro instalado.

O quadro de depressão de imunidade conseqüente à infecção pelo HIV é, sabidamente, uma situação propícia à instalação desses agentes levando a quadros de infecçōes oportunistas. Assim, a elevada freqüência dessas infecçōes mencionadas como causa da morte podem estar encobrindo casos de AIDS.

Seguindo-se a metodologia adotada foram separados os atestados de óbito segundo a menção de AIDS ou das demais doenças, aquelas associadas à síndrome e as demais causas presumíveis de serem manifestaçōes da imunodeficiência.

Do total de 4023 atestados, constituiu-se um subgrupo de 359 atestados onde a causa básica era AIDS ou doenças como sarcoma de Kaposi, pneumocistose e as demais infecções oportunistas que, como é sabido, estão freqüentemente associadas à AIDS. Fizeram parte deste grupo, também, aqueles casos que foram recuperados pela comparação dos atestados do estudo com os dados da vigilância 
epidemiológica de AIDS. A tabela 4 apresenta a freqüência desses casos, segundo ano de ocorrência.

TABELA 4 - Óbitos de indivíduos do sexo masculino, de 20 a 49 anos, segundo grupo de causas ligadas à AIDS, Município de São Paulo, 1983 a 1986.

\begin{tabular}{|c|c|c|c|c|c|c|}
\hline \multirow{2}{*}{ ANO } & \multicolumn{2}{|c|}{ AIDS } & \multicolumn{2}{|c|}{ DEMAIS CAUSAS } & \multicolumn{2}{|c|}{ TOTAL } \\
\hline & № & $\%$ & No & $\%$ & № & $\%$ \\
\hline 1983 & 12 & 1,3 & 879 & 98,7 & 891 & 100,0 \\
\hline 1984 & 37 & 3,9 & 920 & 96,1 & 957 & 100,0 \\
\hline $1985^{(*)}$ & 116 & 11,8 & 864 & 88,2 & 980 & 100,0 \\
\hline 1986 & 194 & 16,2 & 1001 & 83,8 & 1195 & 100,0 \\
\hline TOTAL & 359 & 8.9 & 3664 & 91.1 & 4023 & 100,0 \\
\hline
\end{tabular}

(*) Os atestados de abril de 1985 não foram revisados e portanto nesse total faltam essas declaraçðes.

Observa-se que, com o passar do tempo, a AIDS aparece referida como causa básica cada vez em maior proporção, caracterizando tanto um aumento da epidemia como uma possível melhora no preenchimento dos atestados de óbito.

Os resultados aqui apresentados corroboram os dados dos estudos internacionais onde os óbitos por AIDS, no sexo masculino, manifestaram-se predominantemente em individuos na faixa etária de 30 a 39 anos (38,7\% dos óbitos devidos à síndrome neste trabalho) e solteiros $(50.2 \%)$.

Esses óbitos ocorreram, em sua maioria, em hospitais $(76,7 \%)$ sendo que pode se destacar a grande participação de hospitais públicos, que atendem uma maior demanda, principalmente em vista elevado do custo do tratamento da AIDS.

Ainda que em $10 \%$ dos atestados a informaçāo sobre ocupaçāo era ignorada, as categorias profissionais mais freqüentes, neste estudo, foram os trabalhadores braçais $(12,5 \%)$ e os inativos $(11,4 \%)$. 
Em relação ao grau de instrução, em grande parte dos atestados estudados, esse dado foi ignorado $(40,7 \%)$, quase metade dos indivíduos tinham educação fundamental e apenas $4,9 \%$ tinham nível superior.

As causas de morte mais freqüentes foram as pneumonias e broncopneumonia $(39,07 \%)$, o suicídio $(20,45 \%)$ e a tuberculose $(17,80 \%)$.

\section{2 - CARACTERIZAÇÃO DOS ÓBITOS IDENTIFICADOS NESTE ESTUDO COMO DEVIDO À AIDS}

O Ministério da Saúde identificou como tendo ocorrido, no Brasil, de 1983 a 1986, 1569 casos de AIDS em indivíduos do sexo masculino de todas as idades ${ }^{66}$. Considerando apenas os casos de indivíduos do sexo masculino e maiores de 15 anos, este número passa a 1532 casos no país. Destes 1532 casos, 58 são referentes a hemofílicos, causa básica que não foi selecionada como parte deste estudo. Desta forma o número de casos ocorridos no Brasil, em indivíduos do sexo masculino, com idade mínima de 15 anos, no periodo considerado, excluindo-se os casos de AIDS devido a hemofilia, é de 1474 casos dos quais os 359 óbitos analisados neste estudo representam $24 \%$.

Nesse mesmo periodo, segundo o Centro de Referência e Treinamento-AIDS da Secretaria Estadual da Saúde, foram notificados no Estado de São Paulo, incluindo casos femininos e de todas as faixas de idade, 950 casos e 742 óbitos $^{91}$. Os 359 óbitos por AIDS que fazem parte deste estudo constituem, então $38 \%$ do total de casos e 48,3\% dos óbitos registrados no Estado de São Paulo de 1983 a 1986. 
O Ministério da Saúde ${ }^{67}$ identifica o Municipio de São Paulo como um dos locais de maior incidência no país, com 769 casos registrados entre 1980 e 1986. Assim, ainda que este estudo considere apenas os óbitos do sexo masculino, na faixa etária de 20 a 49 anos, ao serem identificados 359 óbitos ocorridos nesta capital, estes se referem à uma letalidade, no período, de, no mínimo, $47 \%$ pois o denominador aqui considerado, o número total de casos, inclui as mulheres $\mathrm{e}$ as demais idades, além do grupo de 20 a 49 anos que faz parte deste trabalho.

Os dados sobre incidência da AIDS, embora provenientes da mesma fonte, podem apresentar alguma variabilidade. Assim, segundo LIRA ${ }^{55}$ (1992), ocorreram na cidade de São Paulo, de 1983 a 1986, um total de 678 casos de AIDS e 362 óbitos devidos a doença.

Considerando os dados citados acima, pode-se avaliar que este trabalho conseguiu identificar quase a totalidade dos óbitos de AIDS desse período. Os 362 óbitos estudados por $\operatorname{LIRA}^{55}$ e identificados pela Secretaria Municipal de Saúde referem-se a óbitos do sexo masculino e feminino, de todas as idades. Enquanto que os 359 aqui analisados são relativos apenas a indivíduos do sexo masculino e de idade entre 20 a 49 anos, como já citado.

Os 362 óbitos devidos a AIDS, identificados pela Secretaria Municipal de Saúde estão assim distribuídos, segundo ano de ocorrência: 11 ocorreram em 1983, 42 em 1984; 126 em 1985 e 183 em $1986^{55}$.

Comparando estes dados com o que foi apresentado na tabela 4, referente aos óbitos identificados, nota-se que, para os anos de 1983 e 1986 este estudo encontrou mais óbitos do que os registrados no PRO-AIM. $9 \%$ e $6 \%$ a mais, respectivamente. Para os outros anos, a Secretaria Municipal da Saúde registrou mais óbitos que este estudo, embora se referindo ao total de morte por AIDS.

Com certeza muitos dos 359 óbilos de AIDS deste estudo não estão 
contidos entre os 362 óbitos do serviço municipal. Pode-se imaginar, também, que alguns óbitos de indivíduos portadores da síndrome foram identificados apenas por um dos levantamentos, assim como, é possivel, alguns óbitos não tenham sido identificados nem neste estudo nem pela investigação do PRO-AIM.

Ainda que a diferença entre um dado e outro seja muito pequena, é importante esclarecer que os primeiros se referem aos óbitos de indivíduos de todas as idades e ambos os sexos, moradores do Município de São Paulo, enquanto neste estudo são considerados apenas os óbitos de um grupo. Entre estes últimos há a possibilidade de haver óbitos de indivíduos de outro município que faleceram em São Paulo.

Infelizmente outras informações não são disponiveis como, por exemplo, número de casos por sexo e idade segundo município de diagnóstico, o que facilitaria a comparação dos casos registrados com os detectados pelo estudo.

Na tabela 4 são apresentados os óbitos deste estudo segundo grupo de causas, e pode-se notar o aumento da epidemia nesse período. Em 1983, apenas $1,3 \%$ dos atestados entre aqueles selecionados constituíam casos de AIDS. Essa proporção aumentou para 3,9\% em 1984, 11,8\% em 1985 e 16,2\% em 1986.

Os 359 óbitos identilicados pelo estudo como devido à AIDS foram analisados separadamente dos demais 3664 , que constituem o grupo das "demais causas".

\section{1 - Em relaçâo ao estado civil}

Um dos atributos que permite a avaliação de maior ou menor risco de AIDS por transmissão sexual é o estado civil solteiro. Como a epidemia inicialmente atingia indivíduos homossexuais, pessoas que na maioria das vezes nāo se casam, 
a alta freqüência de solteiros em uma população pode indicar a predominância deste tipo de definição sexual e, portanto, maior chance de ocorrência da síndrome.

TABELA 5 - Óbitos por AIDS em indivíduos do sexo masculino, de 20 a 49 anos, segundo estado civil, Município de São Paulo, de 1983 a 1986.

\begin{tabular}{lcc}
\hline Estado Civil & No & \% \\
\hline Solteiro & 294 & 81,9 \\
Casado & 52 & 14,5 \\
Desquitado ou divorciado & 10 & 2,8 \\
Ignorado ou em branco & 3 & 0,8 \\
\hline TOTAL & 359 & 100,0 \\
\hline
\end{tabular}

A alta freqüência de indivíduos solteiros, $81,9 \%$ dos óbitos deste grupo, mostra o que realmente se esperava para um início de epidemia cujo padrão de transmissão era predominantemente entre individuos homossexuais. Isto torna-se evidente na comparação desses dados com a proporção de indivíduos solteiros dos demais óbitos estudados, que foi de $47,1 \%$ enquanto que, nesse mesmo grupo a porcentagem de casados foi de $40,5 \%$.

Um dos estudos de maior importância para o entendimento da epidemia e da história natural da AIDS foi realizado em San Francisco e baseou-se no seguimento de uma coorte de indivíduos solteiros, do sexo masculino, com idade entre 25 e 55 anos, que moravam em uma área da cidade onde a doença era bastante prevalente em $1984^{99}$.

Em estudo sobre avaliação da notificação de AIDS em Ontário, Canadá, de 1985 a 1987, verificou-se que em 1985, o número de pacientes com AIDS que nunca haviam se casado era uma vez e meia maior do que os casados ${ }^{47}$.

MC CORMICK ${ }^{(0)}$ (1988), em estudo sobre tendência da mortalidade por AIDS 
na Inglaterra e País de Gales, mostra que, em 1984, houve 2455 óbitos de indivíduos do sexo masculino, de 25 a 44 anos, que nunca se casaram. Cita, ainda, o que se notou em Nova York, no período de 1980 a 1984, quando houve um aumento de $34 \%$ no total dos óbitos de pessoas do sexo masculino, da faixa de 15 a 64 anos, que nunca se casaram e que, coincidentemente, habitavam uma área onde a população predominante era de homossexuais. A autora, analisando dados de mortalidade da Inglaterra e País de Gales, verificou que a razão de mortalidade padronizada devido às causas associadas à AIDS

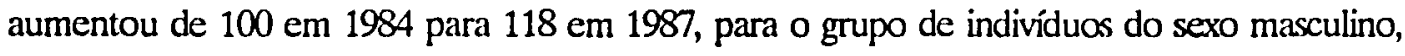
solteiros na faixa de 15 a 54 anos ${ }^{61}$.

\section{2 - Em relação ao local de ocorrência}

Em relação ao local da morte, 95,3\% dos 359 indivíduos desse grupo faleceram em hospitais e o restante $4,7 \%$ no domicilio. Esta alta porcentagem de óbitos hospitalares é esperada, uma vez que a AIDS é uma doença que requer múltiplas internações, onde os pacientes apresentam quadro terminal grave, com o estado geral bastante comprometido. Muitas vezes também há o aparecimento de infecçōes generalizadas e problemas respiratórios graves, ainda assim ocorrem casos onde é dada alta para que eles passem seus últimos dias junto à família.

Comparando o local de ocorrência da morte desse grupo com os demais

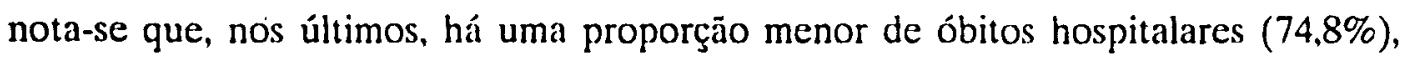
porém há um aumento das mortes em domicílio (16,5\%) e em via pública $(4,2 \%)$.

Esses dados são importantes para que seja feito o planejamento dos leitos hospitalares necessários à grande maioria dos casos dessa síndrome que ainda estão para acontecer, uma vez que o período de incubação do vírus é bastante grande e ainda. não está definitivamente estabelecido. 
2.3 - Em relação ao hospital de ocorrência do óbito

Entre os óbitos que ocorreram em hospitais, em sua maior parte, 30,7\%, aconteceram no Hospital Emilio Ribas, conhecido por atender doenças infecto-contagiosas e constituir um serviço de referência para esse tipo de atendimento. Em relação ao total de óbitos estudados, este hospital passa do 3 lugar para o $1_{-}^{\circ}$, exatamente por atender a maior parte dos casos desta patologia e, também, pela boa qualidade de preenchimento dos atestados de óbito.

O Hospital das Clínicas da Faculdade de Medicina da Universidade de São Paulo, outro serviço de grande demanda, foi citado como local de ocorrência de $10,5 \%$ dos óbitos do grupo de causas relacionadas à AIDS. É também o segundo hospital citado, no conjunto dos óbitos estudados.

O terceiro hospital mais citado entre esse grupo especial foi o Hospital do Servidor Público Estadual, em 9,9\% dos atestados de óbito.

O hospital do Mandaqui, com maior freqüência no total de óbitos, foi mencionado, neste grupo, em $1,8 \%$ dos casos sendo que os demais hospitais citados foram o Hospital Heliópolis (INAMPS), em 4.4\%; Hospital Emilio Ribas II (hoje Centro de Referência e Treinamento-AIDS) $4,1 \%$ e o Hospital Albert Einstein com 3,8\%.

\section{4 - Em relação à idade}

Muitos trabalhos sobre a epidemiologia da Síndrome da Imunodeficiência Adquirida evidenciam a maior incidência da doença entre indivíduos do sexo masculino e também da faixa etária de 20 a $49 \operatorname{anos}^{41,42,56,61,72}$. 
No Município de São Paulo, estudo avaliando dados de morte por AIDS mostra que em 1991 existia uma relação de 5,9 óbitos de pessoas do sexo masculino para cada um do sexo feminino. Quando se analisa a idade, 86,7\% dos óbitos devido à esta causa ocorrem na faixa etária de 20 a $49 \operatorname{anos}^{56}$.

TABELA 6 - Número de óbitos e coeficiente de mortalidade por AIDS de indivíduos do sexo masculino, de 20 a 49 anos Município de São Paulo, de 1983 a 1986.

\begin{tabular}{lrrrrrrr}
\hline \multirow{2}{*}{ Idade(anos) } & \multirow{2}{*}{ No } & \multirow{2}{*}{$\%$} & \multicolumn{5}{c}{ COEFICIENTES $^{(*)}$} \\
\cline { 5 - 8 } & & & $\mathbf{1 9 8 3}$ & $\mathbf{1 9 8 4}$ & $\mathbf{1 9 8 5}$ & $\mathbf{1 9 8 6}$ & TOTAL \\
\hline $20-24$ & 27 & 7,5 & 0,64 & 0,65 & 1,96 & 2,63 & 1,5 \\
$25-29$ & 72 & 20,0 & 0,39 & 1,69 & 4,19 & 6,81 & 3,3 \\
$30-34$ & 109 & 30,4 & 1,20 & 2,03 & 7,68 & 11,97 & 6,0 \\
$35-39$ & 69 & 19,2 & - & 2,15 & 6,65 & 10,60 & 5,1 \\
$40-44$ & 58 & 16,2 & 0,79 & 2,39 & 5,48 & 13,64 & 5,7 \\
$45-49$ & 24 & 6,7 & - & 1,40 & 4,98 & 4,40 & 2,8 \\
\hline TOTAL & 359 & 100,0 & 0,55 & 1,66 & 5,04 & 8,20 & 4,0 \\
\hline
\end{tabular}

(") Coeficiente para 100000 indivíduos do sexo masculino, calculado utilizando população estimada para cada faixa etária e ano e para o meio do periodo, por interpolação (Lagrange).

A tabela 6 indica a faixa etária de 30 a 44 anos como a de maior incidência de óbitos de AIDS, fato igualmente verificado para casos da doença, tanto em nosso meio como em outros países. A OMS estima que a maior parte das infecções pelo HIV ocorreram em indivíduos entre 15 e 49 anos de idade ${ }^{72}$. Os coeficientes apresentados na Tabela 6 mostram, claramente, que a mortalidade pela doença aumentou com o tempo e com a idade.

Em estudo já citado, LUNA e colaboradores ${ }^{56}(1991)$ mostraram que, em 1991, a maior parte dos óbitos devido a AIDS ocorrem em adultos, entre 20 e 49 anos. Assim, do total de óbitos por essa causa, 87,7\% correspondiam a indivíduos do sexo masculino com idade entre 20 e 49 anos. 
Ainda que também ocorram casos em outras faixas etárias, como em menores de 20 e maiores de 50 anos, no período de estudo essa era uma ocorrência incomum. Segundo dados do Ministério da Saúde ${ }^{65}$, os primeiros casos de indivíduos menores de 15 anos aconteceram no segundo semestre de 1984.

No Município de São Paulo, em 1991, entre os óbitos ocorridos por AIDS, apenas $\frac{\text { ? }}{135 \%}$ nāo estavam no grupo de 20 a 49 anos, estes foram distribuídos da seguinte forma: $1,1 \%$ eram de menores de 1 ano; $1,2 \%$ entre 1 e 9 anos; 2,2\% de pessoas de 10 a 19 anos e 8,5\% de indivíduos com 50 anos e mais 56 .

Os casos de AIDS em menores de 20 anos parecem estar associados à transmissão intravenosa, pelo uso de drogas ou à transmissão vertical, da mãe para o filho, considerando os menores de cinco anos. Tanto um tipo de transmissão como outro, por uso de drogas ou vertical, passaram a ser realidade em nosso país no decorrer da segunda metade da década de oitenta.

Ao se comparar o grupo de óbitos por AIDS com o grupo das demais causas de morte, em relação a faixa etária, nota-se que a proporção de individuos aumenta a cada faixa etária nos dois grupos. Porém, no grupo que faleceu por AIDS a proporção de indivíduos de 45 a 49 anos diminui em relação às outras faixas, e no outro grupo ela aumenta.

\section{5 - Em relação à ocupação}

A tabela 7 apresenta as profissōes ou atividades mais citadas nas declaraçōes de óbito dos indivíauos deste grupo. As ocupaçōes estão de acordo com o conhecido e relatado como características do início da epidemia: os primeiros casos 
dos EUA se referiam a profissionais liberais, artistas e indivíduos de estrato sócio-econômico médio e alto. Este fato foi de importância epidemiológica para a disseminação do vírus e, também, para o controle da transmissão da doença.

No que se refere à disseminação do vírus, indivíduos de estrato social elevado viajam com mais freqüência, o que pode representar maior chance de contato com outras populações. Casos relatados como ocorridos antes dos anos oitenta, o início da era da AIDS, sempre estavam relacionados à viagens à África $^{32,37}$.

É conhecida a história do assim denominado "paciente zero", um funcionário de uma companhia aérea que fazia a rota EUA - Europa e que foi o responsável pela introdução do vírus na América do Norte e pela sua disseminação entre a população homossexual da costa leste e oeste dos EUA ${ }^{78}$.

O estilo de vida de alguns tipos de profissionais, entre eles artistas e profissionais liberais, com muitas viagens e intensa atividade social, aumenta as chances de contatos, inclusive os sexuais.

A força da epidemia se fez notar nas grandes cidades americanas quando muitos artistas foram acometidos pela síndrome. $O$ mundo das artes perdeu um número grande de pessoas, peças de teatro foram retiradas de cartaz pela impossibilidade de trabalho de grande parte do elenco. Intelectuais, filósofos, profissionais na fase mais produtiva de suas vidas viram-se, repentinamente, incapacitados de continuar a obra que haviam começado. Este fato teve bastante importância na divulgação das informaçōes sobre a doença, pois estas eram pessoas públicas e cada morte era amplamente noticiada.

No entanto esse grupo de individuos, de maior poder aquisitivo, sócio e culturalmente mais favorecido, onde a epidemia se instalou de início, constitui 
também o grupo onde informações são mais assimiladas, onde a proximidade com casos da doença gerou uma percepção da necessidade de mudança de comportamento, onde se começou a política de controle e onde seus primeiros resultados foram evidenciados.

No presente estudo, a ocupação relatada com mais freqüência, no grupo de óbitos por AIDS ou doenças relacionadas, foi a de bancário e economiário (6,7\%). Desde o início da epidemia em nosso meio, estas foram ocupações reconhecidamente atingidas, levando a se formar, inclusive, serviços de saúde específicos dentro desses setores profissionais .

Atividades profissionais ligadas à arte como decoração e desenho (1,7\%), arquitetura, assim como, algumas ocupaçōes como modista (1,1\%), cabeleireiro $(5,3 \%)$ são ocupaçōes referidas com freqüência entre os óbitos por AIDS analisados neste trabalho. No entanto este dado difere do encontrado no total de óbitos estudado, quando trabalhadores braçais e inativos ou inválidos foram as ocupações mais referidas.

As ocupaçōes dos indivíduos doentes, identificados neste estudo, estão de acordo com a história da epidemia em nosso meio e explicam seu fluxo, sendo introduzida no pais por indivíduos contaminados provavelmente nos EUA, por meio de contatos homossexuais, e que faziam parte de um grupo de renda mais elevada.

O primeiro caso no Brasil ocorreu em 1980 embora só tenha sido identificado após o introdução dos testes para detecção do vírus. Este caso se referia a um fotógrafo que foi contaminado fora do País vindo a falecer em São Paulo, sem que losse conhecida a real causa de sua morte. Dados de autópsia e o teste posterior demostraram se tratar da nova doença recém aparecida ${ }^{5}$. 
TABELA 7 - Óbitos por AIDS identificados no estudo, de indivíduos do sexo masculino, de 20 a 49 anos de idade, segundo ocupação ${ }^{(1)}$. Município de São Paulo, 1983-1986.

\begin{tabular}{|c|c|c|}
\hline Ocupação $^{(1)}$ & No & $\%$ \\
\hline Bancário e economiário (390) & 24 & 6,7 \\
\hline Auxiliar de Escritório (393) & 23 & 6,4 \\
\hline Cabeleireiro (570) & 19 & 5,3 \\
\hline Comerciante (410) & 14 & 3,9 \\
\hline Inativo, incapacitado $(\mathrm{X} 90)^{(2)}$ & 13 & 3,6 \\
\hline Vendedor (451) & 12 & 3,3 \\
\hline $\begin{array}{l}\text { Trabalhador braçal e outros tipos de } \\
\text { atividades (999) }\end{array}$ & 12 & 3,3 \\
\hline Professor sem especificaçāo (140) & 10 & 2,8 \\
\hline Auxiliar de enfermagem (072) & 8 & $2,2:$ \\
\hline Advogado (121) & 8 & 2,2 \\
\hline Professor Universitário (130) & 8 & 2,2 \\
\hline $\begin{array}{l}\text { Administrador de empresa, executivo, } \\
\text { gerente }(240)\end{array}$ & 8 & 2,2 \\
\hline Condutor de veículos a motor (985) & 8 & 2,2 \\
\hline Autônomo e ocupação não identif.(X20) ${ }^{(2)}$ & 7 & 1,9 \\
\hline Médico $(061)$ & 6 & 1,7 \\
\hline Decorador e desenhista (162) & 6 & 1,7 \\
\hline Cozinheiro $(531)$ & 6 & 1,7 \\
\hline Desenhista técnico (038) & 4 & 1,1 \\
\hline Supervisor,inspetor,fiscal, & & \\
\hline chefe,encarregado de seção (300) & 4 & 1,1 \\
\hline Funcionário público $(310)$ & 4 & 1,1 \\
\hline Supervisor de vendas (421) & 4 & 1,1 \\
\hline Garçom, barman (532) & 4 & 1,1 \\
\hline Guarda de segurança (583) & 4 & 1,1 \\
\hline Alfaiate, costureiro, modista (791) & 4 & 1,1 \\
\hline Demais ocupaçōes $\left(^{*}\right)$ & 139 & 39,0 \\
\hline TOTAL & 359 & 100,0 \\
\hline
\end{tabular}

(") As ocupaçöes com freqüência menor que $1 \%$.

(1) De acordo com a Classificaçāo Brasileira de Ocupaçðes para o Subsistema de informaçōes sobre Mortalidade ${ }^{63}$.

(2) Categorias utilizadas pela Fundaçăo SEADE.

Comparando as ocupaçōes mencionadas com mais freqüência entre os indivíduos que tinham AIDS com os demais óbitos do estudo, verifica-se que, 
desses últimos apenas $0,7 \%$ eram bancários; $1,6 \%$ auxiliar de escritório; $0,2 \%$ cabeleireiro e $2.4 \%$ comerciante. As outras ocupaçōes citadas no grupo de AIDS, como advogado ou administrador de empresa, gerente ou executivo, foram mencionadas em $0,2 \%$ dos óbitos por outras causas que não as relacionadas à AIDS.

Somente a partir de 1987, é que a epidemia atingiu outros grupos além dos homossexuais, pois começou a aparecer um número crescente de casos em usuários de drogas intravenosas e em mulheres. Neste último grupo o mais freqüente meio de transmissão é a sangüínea e a partir dessas mulheres contaminadas a AIDS passou a atingir crianças, pela transmissão de mãe para o filho, durante a gestação, no momento do parto ou pela amamentação, o que convencionou-se chamar de "transmissāo vertical".

Desta forma a epidemia que se alastrava no país, atingindo várias localidades inclusive cidades do interior, particularmente do Estado de Sāo Paulo, passou a apresentar um outro padrāo, deixando de ser uma doença limitada a certo estrato social e a determinado comportamento de risco.

Este fato foi também descrito em estudo sobre a mudança do perfil da AIDS no Município de São Paulo (1985-1991) onde são analisadas as diferenças entre os individuos que faleceram por AIDS em 1985 e em 1991. Nesse período a epidemia deixou de ser mais prevalente nos estratos sociais mais elevados para atingir outros estratos de renda. Assim, segundo BARBIERI e colaboradores 6 (1992), em 1985, 13,7\% dos óbitos por AIDS eram de operários enquanto em 1991 esta proporçāo foi de 23,2\%. Indivíduos cuja ocupaçāo pode ser definida como serviços gerais passaram de $0,8 \%$ em 1985 à uma freqüência de 4,5\% em 1991. No entanto profissionais liberais como proprietários e empresários ou gerentes e diretores que em 1985 correspondiam a 3,8\% dos óbitos por AIDS, cada grupo, em 1991 passaram ambos a uma freqüência de $0,7 \%$ do total dos óbitos . 


\section{6 - Em relação ao grau de instrução}

Ao analisar o grau de instruçāo, variável bastante relacionada à ocupação e, como esta, indicadora do nível social, entre os indivíduos que morreram por AIDS observou-se que $26,7 \%$ tinham nivel superior enquanto que nos demais óbitos do estudo este dado era de $2,7 \%$.

Os dois grupos parecem bastante diferentes em relação ao grau de instrução: do grupo que faleceu por AIDS $1,7 \%$ não tinha nenhumànstrução, no outro grupo $4,0 \%$. Com nível secundário ( $2 \%$ grau) havia $22,6 \%$ dos indivíduos com AIDS e apenas 3,9\% dos demais. Em 8,6\% das declarações este dado estava em branco ou ignorado entre os 359 atestados de indivíduos portadores do HIV, enquanto que esta proporção foi de $43,8 \%$ nos demais.

\section{7 - Em relação às causas de morte}

As causas básicas de morte foram selecionadas segundo as regras da CID-9revisāo e portanto, ainda que a AIDS estivesse mencionada, dependendo do local onde foi anotada, por determinação das regras, ela não constituia a causa básica do óbito.

Este fato ocorreu principalmente quando a sindrome foi anotada na linha $b$ ou $c$ da parte médica da declaração e na linha $a$ havia menção de qualquer outra doença infecciosa, como por exemplo a tuberculose, a criptococose ou a toxoplasmose. Segundo as regras de codificação da CID-9a revisão, doenças infecciosas não podem ser consideradas como devido a nenhuma outra causa, ou seja, a seqüência não é aceita. 
As Regras Internacionais de Seleção da Causa Básica, ou "Regras de mortalidade" como sāo conhecidas, surgiram com a sexta revisão da CID, em 1948 e, embora com algumas alteraçōes nas sucessivas revisões, sempre indicaram como seqüência "sumamente improvável" aquela em que uma doença infecciosa era devida a qualquer outra causa ${ }^{73}$.

Após o isolamento do HIV, em 1983, quando a AIDS foi caracterizada como doença infecciosa e, como em geral os óbitos são devidos às complicações que na maior parte das vezes sāo também infecçōes, passou-se a questionar esta disposição para codificação.

Este fato é de interesse e altera sobremaneira as estatísticas pois, ainda que se saiba ser possível a seqüência AIDS levando a qualquer outra doença infecciosa, as regras que determinam a escolha da causa básica do óbito só foram revistas para a $10_{-}^{\mathrm{a}}$ revisão da CID, que já foi aprovada em 1989 e que entrará em vigor no Brasil, em 1995.

A impossibilidade de se ter uma coerência quanto à causa da morte, principalmente porque a infecção pelo HIV propicia a instalação de outras infecções ditas oportunistas, gerou algumas mudanças na aplicação e interpretação das regras de codificaçāo de mortalidade depois do aparecimento da AIDS. Desta forma, na Inglaterra, a partir de 1984 passou-se a aceitar algumas seqüências de causas como possíveis dentre as muitas ditas como sumamente improváveis pelas regras em vigor até então ${ }^{60}$.

No Estado de São Paulo quando existe a AIDS mencionada na declaração de óbito esta é selecionada como a causa básica de morte e é assim considerada para fins estatísticos. Ocorre que esta é uma dctcrminação do Estado de São Paulo apenas e que entrou em vigor em tempo nāo muito bem determinado após o início da epidemia. 
Nos EUA criaram-se códigos especiais na CID-9 para a AIDS e demais intecções oportunistas e estes códigos, ainda que propostos em um período entre duas revisões da CID, passaram a ser utilizados em grande parte do território americano e até em outros países como meio de determinar o número real de casos e óbitos da doença ${ }^{18,70}$.

TABELA 8 - Óbitos por AIDS, de indivíduos do sexo masculino, de 20 a 49 anos, segundo a causa básica referida,Município de São Paulo, de 1983 a 1986.

\begin{tabular}{lrr}
\hline Causa básica & No & $\%$ \\
\hline AIDS (279.1) & 175 & 48,7 \\
Tuberculose (010-018) & 31 & 8,6 \\
Pneumonias e Broncopneumonia (480-486) & 23 & 6,4 \\
Pneumocistose e outras doenças & & \\
infecciosas e parasitárias (136) & 20 & 5,6 \\
Sarcoma de Kaposi (173.9) & 12 & 3,4 \\
Criptococose (117.5) & 12 & 3,4 \\
Abscesso Intracraniano (324.0) & 10 & 2,8 \\
Algumas doenças inflamatórias do & & \\
sistema nervoso central (320-323) & 10 & 2,8 \\
Toxoplasmose (130) & 6 & 1,7 \\
Imunodeficiência (279.3) & 6 & 1,7 \\
Suicídio-(E950-E959) & 4 & 1,1 \\
Septicemia (038.9) & 4 & 1,1 \\
Linfossarcoma e linfoma (200-202) & 4 & 1,1 \\
Tumores benignos e malignos (140-239) & 3 & 0,8 \\
Deficiências Nutricionais (260-269) & 3 & 0,8 \\
Monilíase (112) & 3 & 0,8 \\
Outras pneumonias alveolares (516) & 3 & 0,8 \\
Outras doenças do pulmão (518) & 3 & 0,8 \\
Doença pelo citomegalovírus (078.5) & 2 & 0,6 \\
Infecção por herpes simples (054) & 1 & 0,3 \\
Todas as demais (*) & 24 & 6,7 \\
\hline TOTAL & 359 & 100,0 \\
\hline
\end{tabular}

(") Todas as demais causas de morte citadas como tendo ocasionado a morte dos individuos desse grupo e que nåo estão relacionadas à AIDS. 


\subsection{1 - AIDS e doenças associadas}

Dos 359 óbitos identificados como de indivíduos que tinham a Síndrome de Imunodeficiência Adquirida, em $48,7 \%$ esta foi a causa básica da morte, como mostra a tabela 8. Ao se considerar também o Sarcoma de Kaposi, os casos de pneumocistose, criptococose e citomegalovirose, como doenças mais relacionadas à síndrome, esta proporção atinge $61,5 \%$ dos óbitos estudados.

Nos casos onde a causa básica era a pneumocistose, a AIDS foi mencionada em $80 \%$ dos atestados. Quando a morte foi devido a toxoplasmose, em $66,7 \%$ havia menção da síndrome em alguma parte da declaração, nos casos de criptococose, $16,7 \%$ e quando o SK era a causa básica, a AIDS foi mencionada em $8,3 \%$ dos atestados.

Esse mesmo grupo de causas, indicativas de infecção pelo HIV, foram responsáveis por $79 \%$ dos óbitos devido à AIDS, em um estudo realizado na Califórnia, em 1985 e $1986^{70}$.

Dentre as patologias citadas como causas de morte, várias outras são fortemente indicativas da presença de infecção pelo HIV, como toxoplasmose, infecção pelo herpes simples e monilíase ${ }^{70}$.

As doenças citadas como causa básica neste grupo, onde todos eram casos de AIDS, são bastante coerentes com as patologias associadas à AIDS registradas no momento de notificação da doença. Segundo o Ministério da Saúde ${ }^{67}$, a doença mais freqüentemente associada a casos da sindrome, no período de 1980 a 1984 foi monilíase, presente em $56,1 \%$ dos casos. Ainda que raramente se espere este agente como causa de morte, neste estudo três atestados especificaram a monilíase como causa básica. A PPC foi notificada como doença associada em $29,9 \%$ dos casos de AIDS diagnosticados no período de 1980 a 1984, o SK em 22\%, a 
citomegalovirose e o herpes simples em $14,6 \%$ cada patologia e a criptococose foi a doença associada em $11 \%$ dos casos.

\subsection{2 - Tuberculose}

A tuberculose foi, depois da AIDS, a causa básica mais citada neste grupo, sendo portanto a doença associada mais freqüente, presente em 8,6 \% dos atestados deste grupo. A elevada prevalência dessa patologia em nosso meio explica esses resultados, também verificado no total dos óbitos quando esteve mencionada como causa básica em $17,8 \%$ dos óbitos do estudo.

Em 35,5\% dos óbitos devidos à tuberculose, havia, na declaração, menção de AIDS, embora esta não fosse, devido às regras de codificação, selecionada como a causa básica da morte.

A associação tuberculose e vírus da imunodeficiência adquirida vem sendo bastante estudada, não somente em países desenvolvidos como nos subdesenvolvidos. Assim, tem sido verificado que pacientes tuberculosos apresentam testes positivos para o HIV e o contrário, pessoas infectadas pelo HIV têm maior chance de apresentar quadro clínico de tuberculose ${ }^{72}$.

A tuberculose é a doença associada à AIDS em $20,2 \%$ dos casos notificados ao Ministério da Saúde desde o início da epidemia no Brasil ${ }^{67}$. Segundo esses dados, a tuberculose vem aumentando, pois no período de 1980 a 1984 ela ocorria em $13,4 \%$ dos casos de AIDS.

A concomitância das duas infecções tem sido referida em vários países onde ambas são prevalentes. Na África, de 20 a 44\% dos casos de AIDS apresentam tuberculose, no Haiti esta proporção é de $18 \%$ e pode chegar a $25 \%$ em alguns 
paises da América Latina ${ }^{72}$.

Segundo o Centro de Vigilância Epidemiológica (CVE), em torno de $30 \%$ dos casos de AIDS do Estado de São Paulo apresentam também tuberculose ${ }^{58}$. Neste estudo os dados se referem a tuberculose como causa básica da morte, porém se forem consideradas todas as menções desta, nos atestados de óbito, essa freqüência, com certeza, será maior.

Este fato, da infecção pelo Mycobacterium tuberculosis ser muito prevalente em nosso meio, pode confundir as estatísticas de mortalidade de AIDS. Assim, o PRO-AIM investigando os óbitos por essa causa concluiu que, dos óbitos ocorridos de outubro a dezembro de 1991, a tuberculose foi responsável por $18,5 \%$ do total de mortes por doenças de notificação compulsória ${ }^{82}$.

A tuberculose, ainda que continue a ser um problema dos países em desenvolvimento, é hoje uma ameaça grande também aos países industrializados. A OMS estimou que, até 1990, um terço da população mundial teria evidências de infecção pelo Mycobacterium tuberculosis ${ }^{72}$. A proporção de infectados é praticamente igual em todos os locais, porém nos países desenvolvidos $20 \%$ dos infectados têm menos de 50 anos, enquanto que nos subdesenvolvidos esta proporção é de $75 \%{ }^{72}$.

Nos EUA, após um período de mais de 30 anos de declínio da incidência de tuberculose, esta começou a aumentar a partir de 1985. Nesse país a vigilância da doença, que começou em 1953, só identificou uma elevação nas taxas após 1985, sendo que foi a primeira vez que houve, em 1986, aumento de casos de tuberculose naquele país. Estima-se que de 1985 a 1990, 28.000 casos de tuberculose tenham ocorrido provavelmente devido à $\operatorname{AIDS}^{72,87}$.

Em Uganda, $66 \%$ dos pacientes recém diagnosticados como tuberculosos são tambẻm portadores do HIV. Esta ocorrência de infecção por dois agentes é 
verificada nos demais paises africanos, onde tanto a AIDS como a pobreza são características fortes, em uma proporção que varia de 20 a $60 \%{ }^{72}$.

No Haiti, ao testarem 274 pacientes com baciloscopia positiva, obtiveram uma prevalência de $24 \%$ de positividade para o vírus da imunodeficiência adquirida, enquanto que em pacientes de outras clínicas, usados como controle, essa porcentagem foi de $3 \%$. Este resultado mostra que, no Haiti, o risco de tuberculose em indivíduo HIV positivo é 16 vezes maior que nos demais para a mesma faixa etária do estudo, a saber, dos 20 aos $39 \operatorname{anos}^{72}$. Esse estudo, da OMS, apresenta dados de infecção pelos dois agentes em vários locais e com esses dados estima que entre 30 e $40 \%$ dos casos incidentes de tuberculose. na África e no Caribe, sejam devidos à infecção pelò HIV.

Este aumento do número de casos de tuberculose também é notado no sudoeste Asiático onde o HIV foi introduzido mais recentemente e tem sido referido que a soroprevalência para o HIV, entre pacientes tuberculosos, está aumentando. Na India, 6,3\% dos pacientes admitidos por tuberculose, em um hospital de Bombaim, apresentaram sorologia positiva para o $\mathrm{HIV}^{72}$.

O quadro que se apresenta é bastante grave. A OMS estimou, para o início de 1992, em 4 milhōes o número de pessoas infectadas por ambos. Além disso, o risco de um portador do vírus da AIDS desenvolver tuberculose ativa é muito maior do que os indivíduos soronegativos. $E$ importante citar o fato que muitas vezes a tuberculose é extrapulmonar tornando mais difícil se fazer o diagnóstico e a intervenção precoce ${ }^{72}$.

No Município de São Paulo, dados do PRO-AIM referentes ao período de janeiro a março de 1992 indicam que, entre as mortes devidas a doenças de notificação compulsória, a AIDS e a tuberculose juntas representam $88,7 \%$ dos óbitos $^{84}$. Considerando o total de óbitos desse período, a AIDS e a tuberculose são responsáveis por $5,2 \%$ das mortes do município. 
O papel da tuberculose na epidemia de AIDS é inegável visto que, considerando-a como causa básica de morte, foi mais freqüente que outras doenças indicativas de AIDS, como o Sarcoma de Kaposi $(3,4 \%)$, a criptococose $(3,4 \%)$ e a toxoplasmose $(1,7 \%)$

A tuberculose, doença aparentemente sob controle nos países do primeiro mundo, volta a ameaçar pois, além de se alastrar entre os indivíduos HIV positivos, pode reativar casos de infecções latentes além de se transmitir com facilidade nas populações não protegidas ${ }^{72,87}$.

\subsection{3 - Pneumonias e broncopneumonia}

Um dos grupos de doença citado com freqüencia como causa básica é o das pneumonias e broncopneumonias, que em grande parte traduzem quadros terminais além de encobrir casos de pneumocistose não diagnosticados. Entre os casos de AIDS estudados, elas foram a terceira causa mais citada, responsáveis por $6.4 \%$ dos óbitos, como indica a tabela 8. Considerando o total de óbitos, este foi o grupo de maior frequêencia, responsável por $39 \%$ das mortes.

Mortes atribuídas à pneumonia eram mais comum em indivíduos idosos antes do advento da epidemia de AIDS. Nas localidades onde a AIDS é muito prevalente a pneumonia tem sido referida, com freqüência, como causa de morte de indivíduos jovens, entre 25 e 44 anos. Em Nova York, o coeficiente de mortalidade por pneumonia, de indivíduos do sexo masculino, de 25 a 44 anos, passou de 4,2 por 100000 habitantes em 1978, para 19,1 por 100000 habitantes

em $1987^{95}$. Uma investigaçāo em dados clínicos desse grupo de doentes que morreram devido à pneumonia revelou que $80 \%$ eram do grupo de comportamento 
de risco para AIDS. Desses, $82 \%$ eram usuários de drogas intravenosas e $14 \%$ apresentavam condições que preenchiam os critérios de caso de AIDS do $\mathrm{CDC}^{95}$.

Estudo realizado em Londres, onde foi avaliada a extensão da subnotificação de óbitos por AIDS, detectou uma epidemia de mortes por pneumonia entre indivíduos do sexo masculino, com idade entre 15 e 55 anos. Esta patologia apareceu mencionada como causa básica em 21 atestados desse grupo, em 1987, quando ocorria, em média, com uma freqüência 4 ou 5 óbitos anuais. Este trabalho identificou também um aumento de mortes por doenças infecciosas entre indivíduos jovens do sexo masculino. Após investigação os autores verificaram que este grupo era constituído por mortes declaradas por um número restrito de médicos, sendo que todos trabalhavam com pacientes com Síndrome da Imunodeficiência Adquirida ${ }^{11}$.

Pneumonia, pneumonite ou broncopneumonia foram as causas mais referidas em atestados de óbito de casos de AIDS notificados na Inglaterra e País de Gales, como verificou $\mathrm{McCORMICK}^{60}$ (1988). Essa autora conseguiu identificar 101 óbitos de doentes de AIDS onde esta não estava mencionada na declaração. Em 31 delas (30,7\%), a causa básica era um dos diagnósticos citados acima, pneumonia, pneumonite ou broncopneumonia. A especificação de morte devido à pneumonia por Pneumocystis carinii ocorreu em 16\% dos atestados porém, ainda que esta seja reconhecidamente uma infecção ligada à AIDS, esta síndrome não era anotada na declaração.

Neste estudo, como já foi mencionado, a AIDS apareceu citada, na parte médica, de $80 \%$ dos atestados onde a causa básica era a pneumocistose.

Um estudo em Ontário, Canadá, também apontou a pneumonia, quer especificada como devido ao Pneumocystis, quer sem especificação, junto com o Sarcoma de Kaposi, como a maior proporção de causas de morte de indivíduos com AIDS. Ao serem revisados os atestados de 1985 a 1987,o Pneumocystis carinii 
esteve mencionado como causa básica em $26,4 \%$ dos atestados ${ }^{47}$.

\subsection{4 - Linfossarcomas e linfomas}

Este estudo detectou quatro óbitos de indivíduos infectados pelo HIV onde a causa básica era linfossarcoma ou linfoma. Estas patologias podem sugerir infecção pelo HIV pois muitos casos de linfoma são associados à AIDS. O Min.S. registra que em 3,0\% do total de casos de AIDS notificados no período de 1980 a 1984 o linfoma é a doença manifesta da infecção pelo HIV. A freqüência de outras neoplasias, excluindo o linfoma, como doença associada foi de $1,8 \%$ dos casos registrados nesse período ${ }^{67}$.

HARDY e colaboradores ${ }^{41}$ (1987), em estudo onde revisaram atestados de óbito com a finalidade de avaliar o sistema de vigilância da AIDS, incluíram linfomas não-Hodgkin como causa a ser investigada pela possibilidade de mascarar uma infecção pelo HIV, além dessa patologia constar da lista do CDC de doenças associadas à AIDS (anexo 1). No entanto todos os atestados cuja causa de morte era o linfoma não-Hogdkin em portadores do HIV, haviam sido notificados, como concluíram os autores ${ }^{41}$.

DONOVAN $^{31}$ (1991) avaliando a consistência das estatísticas de mortalidade por AIDS na Austrália, chama a atenção para o fato da incidência de linfoma não-Hodgkin ter aumentado no período de 1979 a 1988. Estas taxas dobraram para o sexo feminino e aumentaram $76,3 \%$ no sexo masculino, na faixa etária de 15 a 54 anos. 


\subsection{5 - Suicídio}

O suicídio foi a $2^{\mathrm{a}}$ causa básica mais citada nos atestados de óbito desse grupo etário. Apesar disso, entre o grupo de óbito de casos de AIDS, esta condição só foi mencionada como causa básica em 4 atestados $(1,1 \%)$. Chama a atençāo, também, o fato que a AIDS só foi mencionada em um desses quatro atestados. A recuperação dessas informaçōes só foi possivel pela comparação dos dados de vigilância com os de mortalidade e, acredita-se que, entre as 823 mortes por suicídio deste estudo, possam existir alguns casos de AIDS não identificados como tal e cuja informação não poderá ser recuperada, uma vez que não existe a notificação destes como casos de AIDS.

\subsection{6 - 'Todas as demais causas de morte}

Foram agrupadas como "demais causas" as seguintes patologias mencionadas como causa básica de óbito de indivíduos portadores do HIV ou com AIDS: encefalite viral e meningoencefalite (2 casos); carcinomatose (2); doença linfoproliferativa (1); neoplasia do encéfalo (1); leucemia (1); edema cerebral (1); enterites e gastrenterites (1) e infecção bacteriana (1). Algumas delas, como edema cerebral, encefalite ou meningoencefalite, são quadros coerentes com as manifestações da AIDS no sistema nervoso. $O$ fato de terem ocorrido em indivíduos infectados pelo HIV pode traduzir tanto a falta de diagnóstico dessa infecção como a omissão da verdadeira causa básica da morte no atestado de óbito.

Ao revisar os atestados de óbito da Inglaterra e País de Gales, McCORMICK ${ }^{60}(1988)$ encontrou entre as causas básicas de óbito dos casos notificados de AIDS 3\% de carcinomatose; $4 \%$ de câncer da boca ou língua; 
$4 \%$ de encefalite e $3 \%$ e abscesso cerebral . A autora relata a ocorrência de outras causas de morte entre esses atestados investigados, tendo encontrado também casos onde o edema cerebral, a gastroenterite, a hemorragia subaracnóidea, a insuficiência renal aguda, a doença pulmonar obstrutiva crônica, o infarto do miocárdio ou a pancreatite, eram as causas básicas da morte.

Entre as doenças informadas no AO como causa de morte em indivíduos com AIDS, encontrou-se, neste estudo, menção de um caso de leucemia. Este fato é curioso, pois a leucemia é uma patologia que até o momento nāo foi descrita na literatura como associada à AIDS. Os dados do atestado de óbito são insuficientes para uma análise mais completa sobre a associação destas duas patologias.

Ainda que, há vários anos, grandes esforços estejam sendo direcionados para levar aos médicos informaçōes de como preencher, adequadamente, a parte médica do atestado de óbito, este preenchimento ainda não é satisfatório. Encontram-se, com certa freqüência, atestados onde a causa básica mencionada é um sintoma ou um achado, como edema cerebral, febre, anemia, para citar apenas as identificadas nas declaraçōes de morte de indivíduos desse grupo.

O fato deste estudo ter excluído os óbitos devido a causas indeterminadas impede uma análise mais profunda da relação entre esse grupo de causas e a ocorrência de AIDS. Embora o Município de São Paulo seja um local onde a assistência médica é, reconhecidamente, a melhor do país e onde os dados são mais confiáveis, ainda assim há uma pequena proporção dos óbitos por causas mal definidas ou indeterminadas.

Ao se fazer a seleção dos atestados que iriam pertencer a este estudo, chamou atenção a grande proporção de declarações de óbito onde a causa básica mencionada era hepatose aguda. Esta é, surpreendentemente, mencionada em atestados de morte preenchidos por um dos serviço de verificação de óbito 
do Município de São Paulo. A existência deste tipo de informação, prestada supostamente após uma necropsia, impede que qualquer análise de dados de mortalidade seja feita sobre o total de óbitos do município.

Entre os muitos casos onde a hepatose aguda era citada como causa de morte, foi possivel obter informação que dois $(0,5 \%$ do total do grupo) se referiam a pacientes sabidamente doentes de AIDS. Os atestados com esta causa, hepatose aguda, não fazem parte deste estudo. Estes dois casos foram incluídos, uma vez que, pela busca nominal entre os casos notificados, conseguiu-se obter a informação de que eram casos de AIDS.

\section{3 - A NOTIFICAÇĀO DOS CASOS}

Dos 4023 atestados selecionados para o estudo, foram recuperadas informaçōes de 359 casos de AIDS, como já foi mencionado. O conhecimento das causas básicas ligadas à AIDS e a comparação com os dados da vigilância epidemiológica permitiram dividir os casos segundo a causa mencionada e a existência de notificação do caso, como pode ser verificado pela tabela 9.

Em relação à possibilidade de, com o passar do tempo, e o aumento do número de casos, a doença ser mais notificada, não foi isto o verificado. Em 1983, $83,3 \%$ dos casos identilicados neste estudo foram notificados, em $1984,81,1 \%$, no ano de 1985, 91,4\% dos óbitos estudados haviam sido notificados e, em 1986, 82\%.

A subnotificação de casos de AIDS identificada por este estudo é próxima à da Califórnia, EUA, onde, pela comparação dos dados de mortalidade com 
os da vigilância epidemiológica, para 1986, esta subnotificação foi de $17 \%{ }^{70}$.

TABELA 9 - Óbitos de indivíduos com ADS, do sexo masculino, de 20 a 49 anos, segundo causa básica e notificação, Município de São Paulo, 1983-1986.

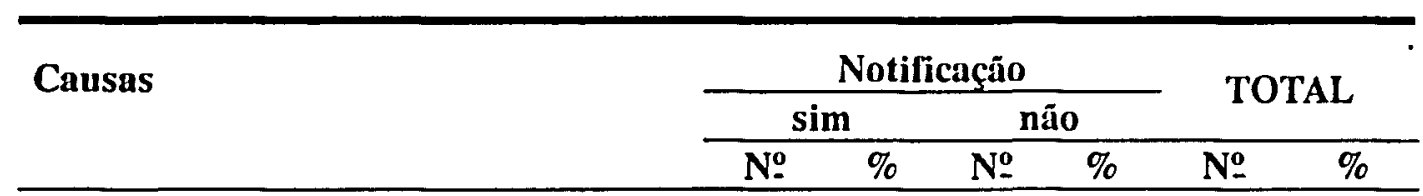

$\operatorname{AIDS}^{(*)}$ como causa básica (CB)

AIDS, não como causa básica

Doenças relacionadas à AIDS como $\mathrm{CB}$

Outras doenças como $\mathrm{CB}^{(1)}$

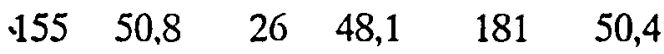
$(85,6)$ $(87,7)$

$26 \quad 8.5$ $(70,3)$

5317,4 $(88,3)$
$(14,4)$

8122,6

$(100,0)$
$37 \quad 10,3$

$(100,0)$
$60 \quad 16,7$

$(100,0)$

Total

305100,0

$54 \quad 100,0$

359100,0

( ${ }^{\circ}$ AlDS ou imunodeficiência sem outra especificação

(1) recuperados pela busca nominal dos casos notificados através dos atcstados de óbito e por outras fontes de informaçăo.

Nesta tabela o enfoque básico é a notificação e a menção de AIDS em qualquer linha da parte médica do atestado de óbito. O critério de notificação dividiu os dados em dois grupos e a menção de AIDS em outros quatro grupos. Assim cada atestado foi contado apenas uma vez, se houvesse menção de AIDS ele era considerado como tal, se não houvesse menção desta síndrome ele era agrupado segundo a causa básica, doenças relacionadas à AIDS ou outras doenças como causa básica da morte.

Dos 359 casos identificados como AIDS, quer por estar mencionada como a causa básica ou mesmo por outras informações adicionais obtidas, $85 \%$ haviam 
sido notificados como caso de AIDS ao SVE até abril de 1992.

A AIDS ou uma imunodeficiência estiveram mencionadas em $73 \%$ do total dos atestados deste grupo, sendo que em 181 ela era a causa básica do óbito. Desses, havia a notificação em $85,6 \%$, sendo que os demais casos não eram reconhecidos pelo SVE, o que só foi possível através deste estudo.

Além das mortes onde à AIDS foi registrada como causa, houve 37 casos $(10,3 \%)$ nos quais doenças relacionadas a ela estavam mencionadas como causa básica. Estas doenças, como sarcoma de Kaposi ou pneumocistose, traduzem a infecção pelo HIV, ainda que esta não esteja explícita na declaração do óbito. Entre os 37 casos ocorridos por doenças associadas à AIDS e que poderiam ser assim considerados, $70,3 \%$ eram casos notificados. A omissão da AIDS como a verdadeira causa da morte, nesses que eram casos notificados, pode traduzir o estigma da doença, outros motivos para tal procedimento serão comentados em outra parte deste trabalho.

Houve também 60 atestados (16,7\%), de indivíduos que eram casos de AIDS, onde outras patologias não relacionadas à AIDS foram mencionadas como causa da morte. Como já foi citado, estes puderam ser recuperados utilizando-se dados da vigilância epidemiológica e buscando ativa e nominalmente os atestados referentes aos casos notificados. Desta forma foram recuperados os atestados de 53 que eram casos notificados e cuja causa básica da morte não indicava doença relacionada à infecçāo pelo HIV. Os demais 7 casos só foram recuperados por informaçōes vindas de outras fontes, tais como imprensa, familiares ou mesmo através de serviços de saúde, ainda que sem o preenchimento da ficha de notificação do caso.

Esses sete casos não notificados, onde não há nenhuma indicação sobre AIDS, representam $1,9 \%$ das mortes pela doença no período e dão uma idéia sobre a proporção de casos de AIDS que não são identificados a não ser através de uma investigação. 


\section{1 - Casos de AIDS não notificados e identificados pelo estudo}

Entre os casos não notificados, 54 no total, chama a atenção a ocorrência de 36 casos onde a AIDS estava declarada na DO sem que houvesse a notificação dos casos. Em 26 (72\%) desses 36 atestados, a AIDS era a causa básica segundo as regras de codificaçāo e nos outros 10 casos esta síndrome estava mencionada na parte médica do atestado de óbito.

\subsection{1 - Em relação à idade}

Comparando os 305 casos notificados com os 54 que não haviam sido informados como caso de AIDS ao SVE, tem-se, em relaçāo à idade, uma tendência a idades mais altas no grupo dos casos não notificados como mostra a tabela 10 .

TABELA 10 - Óbitos por AIDS, de indivíduos do sexo masculino, segundo idade e notificação, Município de São Paulo, 1983-1986.

\begin{tabular}{|c|c|c|c|c|c|c|}
\hline \multirow{3}{*}{ Faixa etária } & \multicolumn{4}{|c|}{ Notificaçầo } & \multirow{2}{*}{\multicolumn{2}{|c|}{ TOTAL }} \\
\hline & \multicolumn{2}{|c|}{$\sin$} & \multicolumn{2}{|c|}{ กão } & & \\
\hline & № & $\%$ & № & $\%$ & № & $\%$ \\
\hline $20-24$ & 26 & 8,5 & 1 & 1,9 & 27 & 7,5 \\
\hline $25-29$ & 65 & 21,3 & 7 & 13,0 & 72 & 20,0 \\
\hline $30-34$ & 88 & 28,9 & 21 & 38,9 & 109 & 30,4 \\
\hline $35-39$ & 59 & 19,3 & 10 & 18,5 & 69 & 19,2 \\
\hline $40-44$ & 47 & 15.4 & 11 & 20,4 & 58 & 16,2 \\
\hline $45-49$ & 20 & 6,6 & 4 & 7.4 & 24 & 6,7 \\
\hline TOTAL & 305 & 100,0 & 54 & 100,0 & 359 & 100,0 \\
\hline
\end{tabular}


Ainda que o grupo não notificado seja em menor proporção, nota-se que os individuos deste são mais velhos, $57,4 \%$ têm entre 30 e 39 anos, enquanto que a faixa de 20 a 29 anos representa $14,9 \%$ do total do grupo. O grupo de casos notificados é constituído por indivíduos mais jovens (29,8\% estão na faixa de 20 a 29 anos). As idades mais avançadas talvez possam sugerir indivíduos com melhores condiçōes_econômicas e, conseqüentemente, maior possibilidade de ter atenção médica privada e de omissão do caso ao sistema de vigilância epidemiológica.

\subsection{2 - Em relação ao estado civil}

Os indivíduos solteiros constituem a grande maioria dos casos, tanto no grupo dos notificados como nos não notificados $(83,0 \%$ e $75.9 \%$, respectivamente). Chama a atenção a maior proporção de homens casados no grupo que não tinha notificação (18,5\%), quando comparados aos $13,8 \%$ do outro grupo. Considerando casados e separados, a proporção cresce para $24,1 \%$ do total de óbitos não notificados e $16,1 \%$ do total dos casos conhecidos como AIDS, por notificação.

Ao se testar a associação entre estado civil e a existência de notificação do caso, esta resultou não estatisticamente significante.

O estado civil é uma informação que pode indicar maior chance de comportamento de risco. Indivíduos solteiros estão mais sujeitos à vida sexual com maior número de parceiras(os) e portanto mais expostos. Um dos motivos de haver maior proporção de casados entre aqueles não notificados seria a falta de diagnóstico médico da síndrome, ou de pesquisa da doença, indivíduos casados omitem comportamentos de risco, o que atrapalha o raciocínio clínico e interfere na conduta médica. 


\subsection{3 - Em relação ao local de ocorrência do óbito}

Tanto entre os casos notificados como nos não notificados, a quase totalidade dos óbitos foram hospitalares (96,4\% e $89 \%$, respectivamente). A maior porcentagem de óbitos no domicílio, $11 \%$, como era esperado, ocorreu no grupo de casos não notificados, enquanto esta proporção foi de $3,6 \%$ no grupo de casos notificados. A associaçāo entre local do óbito, no hospital ou em domicílio, e a existência de notificação mostrou-se estatisticamente significante $(p<0,028)$.

Pelo tipo de vigilância exercida, de forma ativa, em nosso meio, é esperado que todos os óbitos hospitalares sejam casos notificados. A notificação deve ocorrer quando o indivíduo é internado pela primeira vez em qualquer serviço de saúde. As informaçōes são centralizadas e constantemente avaliadas para que sejam excluídas as notificaçōes duplicadas.

\subsection{4 - Em relação ao hospital onde ocorreram os óbitos}

Dos 54 casos de AIDS identificados por este estudo, 48 ocorreram em hospitais sendo que $22,2 \%$ desses em dois grandes hospitais públicos da cidade; 9,3\% em hospital de convênio; $7,4 \%$ em dois grandes hospitais privados que, no entanto, aceitam convênio; $7,4 \%$ em hospital que atendem servidores públicos e $5,6 \%$ dos casos em hospitais da previdência.

Dividindo os hospitais em dois grupos, um dos quais contendo os hospitais públicos e os filantrópicos e o outro os hospitais privados, houve uma diferença, estatisticamente significante, em relação à notificação do caso ( $p<0,00001)$. 
O fato de não haver notificação de casos cujos óbitos ocorreram em um grande hospital escola chama a atenção, principalmente porque em todos os atestados a AIDS, ou doença relacionada a ela, era causa básica. Em outro grande hospital de doenças infecciosas, entre os casos não notificados, $2 / 3$ dos atestados indicavam AIDS ou doença associada como a causa da morte e $1 / 3$ indicava outras doenças, porém havia também a menção de AIDS.

A suspeita que em hospitais privados a notificação é menor que nos hospitais públicos não foi confirmada neste estudo. Em alguns desses hospitais, tanto os públicos como os privados, a proporção de casos notificados foi a mesma que de casos não notificados. Outros hospitais privados mostraram uma maior freqüência de casos não notificados entre os óbitos que ocorreram em suas dependências e foram devido à AIDS.

\subsection{5 - Em relação à ocupação e ao grau de instrução}

As ocupaçōes mais freqüentes em cada grupo aqui considerado permitiam apenas uma suposição de que atividades mais especializadas seriam mais referidas entre casos não notificados. A possibilidade de acesso a serviço médico privado aumentaria as chances de não notificação do caso.

Esta suposição parece ter encontrado respaldo nos dados deste estudo pois entre os casos nāo notificados há mais referências às profissōes de nível universitário em relação aos casos notificados. Pode-se notar também que, entre os que haviam sido notificados, existe maior proporção de trabalhadores braçais ou sem especificação.

Esta idéia é fortalecida pelo fato que entre as profissões referidas nos atestados de óbito dos casos estudados houve uma subnotificação de casos de $25 \%$ 
quando a profissão era advogado ou professor universitário, 33\% quando a ocupação era decorador, $28,5 \%$ de comerciantes e, no entanto, uma subnotificação bem menor $(10,5 \%)$ quando o indivíduo era cabeleireiro e $8,3 \%$ quando a ocupação do indivíduo era vendedor.

Algumas ocupaçōes, a maioria de nivel universitário, só apareceram no grupo dos casos nāo notificados: economista, jurista e publicitário, por exemplo. As ocupaçōes mais freqüentes aparecem mencionadas em ambos os grupos com uma taxa de subnotificação semelhante. Assim, entre os bancários, economiários e administradores de empresas, $12,5 \%$ dos óbitos se referiam a casos de AIDS não notificados.

A associação entre ocupação e a notilīcação do caso não foi feita porque o agrupamento, em poucas categorias profissionais, necessário para este tipo de análise tornaria sem sentido esta associaçāo.

Em relação ao grau de instrução, a tabela 11 indica a proporção de indivíduos por grau de instrução segundo os grupos de notificados e não notificados.

TABELA 11 - Óbitos por AIDS, indivíduos do sexo masculino, de 20 a 49 anos, segundo notilïcação e grau de instrução, Município de São Paulo, 1983-1986.

\begin{tabular}{|c|c|c|c|c|c|c|}
\hline \multirow{2}{*}{$\begin{array}{l}\text { Grau de } \\
\text { Instrução }\end{array}$} & \multicolumn{4}{|c|}{ Notificaçāo } & \multicolumn{2}{|c|}{ TOTAL } \\
\hline & N: & $\%$ & No & $\%$ & No & $\%$ \\
\hline nenhum & 4 & 1,3 & 2 & 3,7 & 6 & 1.7 \\
\hline fundamental ? & 123 & 40,3 & 22 & 40,7 & 145 & 40,4 \\
\hline $2^{\circ}$ grau $\left.\right|^{w}$ & 70 & 23,4 & 11 & 20,4 & 81 & 22,6 \\
\hline superior $\left.\right|_{\text {, why }} ^{\text {wh }}$ & 79 & 25,9 & 17 & 31,5 & 96 & 26,7 \\
\hline ignorado & 29 & 9,5 & 2 & 3,7 & 31 & 8,6 \\
\hline TOTAL & 305 & 100,0 & 54 & 100,0 & 359 & 100,0 \\
\hline
\end{tabular}


O nível de instrução fundamental é o mais freqüente em ambos os grupos, porém entre os casos não notificados a porcentagem de indivíduos com nível superior é um pouco mais elevada do que entre os casos notificados.

A análise da associaçāo entre grau de instrução e notificação do caso, agrupando os indivíduos sem instrução ou com nível fundamental e comparando-os aos demais, mostrou não haver diferença estatisticamente significante entre essas duas variáveis.

\subsection{6 - Em relação à causa básica do óbito}

Como já foi citado anteriormente, em 26 atestados a causa básica era AIDS em casos não conhecidos pelo serviço de vigilância epidemiológica. Em 21 desses atestados a AIDS era citada como tal e em 5 a menção era "imunodeficiência".

Entre as causas mencionadas como responsáveis pela morte, no grupo dos 54 atestados sem notificação do caso, as mais freqüentes, além da AIDS, foram 5 casos (9,3\% dos casos não notificados) onde a causa básica era criptococose, 3 casos $(5,6 \%)$ onde havia menção de uma forma de tuberculose, 2 óbitos $(3,7 \%)$ causados pelo Sarcoma de Kaposi, 2 casos de pneumocistose como causa básica da morte e a toxoplasmose, infecção pelo citomegalovírus e monilíase foram citados uma vez cada uma como causa de morte desse grupo. A tabela 12 indica a proporção de casos notificados e não notificados segundo a causa básica. 
TABELA 12 - Óbitos por AIDS em individuos do sexo masculino, de 20 a 49 anos, segundo causa básica e notificação do caso, Município de São Paulo, 1983-1986.

\begin{tabular}{|c|c|c|c|c|c|c|}
\hline \multirow{3}{*}{ Causa básica } & \multicolumn{4}{|c|}{ casos } & \multirow{2}{*}{\multicolumn{2}{|c|}{ TOTAL }} \\
\hline & \multicolumn{2}{|c|}{ notificados } & \multicolumn{2}{|c|}{$\begin{array}{c}\text { nāo } \\
\text { notificados }\end{array}$} & & \\
\hline & No & $\%$ & № & $\%$ & No & $\%$ \\
\hline AIDS & 154 & 88,0 & 21 & 12,0 & 175 & 100,0 \\
\hline Imunodeficiência & 1 & 16,7 & 5 & 83,3 & 6 & 100,0 \\
\hline Tuberculose & 28 & 90,3 & 3 & 9,7 & 31 & 100,0 \\
\hline Pneumonia,BCP & 21 & 91,3 & 2 & 8,7 & 23 & 100,0 \\
\hline Pneumocistose & 18 & 90,0 & 2 & 10,0 & 20 & 100,0 \\
\hline Sarcoma de Kaposi & 10 & 83,3 & 2 & 16,7 & 12 & 100,0 \\
\hline Criptococose & 7 & 58,3 & 5 & 41,7 & 12 & 100,0 \\
\hline Absc.Intracraneano & 9 & 90,0 & 1 & 10,0 & 10 & 100,0 \\
\hline D.Sist. Nervoso & 9 & 90,0 & 1 & 10,0 & 10 & 100,0 \\
\hline Toxoplasmose & 5 & 83,3 & 1 & 16,7 & 6 & 100,0 \\
\hline Linfoma,linfossarcoma & 3 & 75,0 & 1 & 25,0 & 4 & 100,0 \\
\hline Moniliase & 2 & 66,7 & 1 & 33,3 & 3 & 100,0 \\
\hline Pneumonia alveolar & 2 & 66,7 & 1 & 33,3 & 3 & 100,0 \\
\hline Citomegalovirose & 1 & 50,0 & 1 & 50,0 & 2 & 100,0 \\
\hline Todas demais & 35 & 83,3 & 7 & 16,7 & 42 & 100,0 \\
\hline TOTAL & 305 & 85,0 & 54 & 15,0 & 359 & 100,0 \\
\hline
\end{tabular}

Estes casos não notificados correspondem a uma taxa de subnotificação de $15 \%$ dos óbitos por AIDS, o que é próxima à encontrada em estudo realizado em um distrito de saúde de Londres, onde foi detectado $19 \%$ de subnotificação de casos de AIDS, verificado pelos dados de mortalidade por AIDS dessa área ${ }^{11}$.

Em Ontário, Canadá, a porcentagem de subnotificação de casos de AIDS, mensurada pelos dados de óbito, foi de 18,9\% em 1985, 28,5\% em 1986 e 24,6\% em 1987, totalizando, no período, uma falta de notificação de $24,8 \%$ do total dos 
$\operatorname{casos}^{47}$. No Município de São Paulo, as taxas de subnotificação foram semelhantes, $16,7 \%$ em 1983, 18,9\% em 1984, 8,6\% em 1985 e $18 \%$ em 1986, como pôde ser determinado por este estudo.

As estatísticas de mortalidade oferecem uma possibilidade de se completar os dados da vigilância epidemiológica pois, ainda que realizada de forma ativa, dificilmente abrange o total dos casos da doença. Nos Estados Unidos este sistema abrange uma porcentagem de cobertura variando de 83 a $100 \%$ do total dos casos de AIDS, dependendo da cidade ${ }^{41}$.

O sistema de vigilância dificilmente consegue captar informações sobre a totalidade dos casos mesmo nos países onde este número é pequeno. Na Austrália, por exemplo, os registros oficiais identificaram para o ano de 1988140 óbitos por AIDS, enquanto que um Estudo do "National Centre in HIV Epidemiology and Clinical Research" identilicou 205 mortes devido à infecção pelo HIV, o que indica um sub-registro da ordem de $31,7 \% 31$.

É bastante claro que ambos os sistemas de coleta de informaçāo, a vigilância e as estatísticas de mortalidade, podem se completar e assim tornar mais útil os dados que produzem. Nesta linha de atuação, o PRO-AIM investigou 333 mortes por causas presumiveis de ser decorrentes da AIDS, no período de outubro de 1989 a maio de 1992, como já foi citado. Do total de mortes investigadas obteve resposta em 159 e, destes, em 37 (23\%) a AIDS era a verdadeira causa de morte. Estas informações permitiram também a atualização dos dados de vigilância epidemiológica ${ }^{55}$.

Este estudo contribuiu com informaçōes sobre 54 casos $(15,0 \%)$ que não eram notificados e que só puderam ser identificados pela metodologia de revisão dos atestados de óbito e pela comparação com os dados da vigilância.

A importância desse número de casos não computados pelo sistema, ainda 
que em alguns atestados a AIDS fosse mencionada, se traduz pelo aumento da prevalência e da letalidade da AIDS em nosso meio.

Considerando o Estado de São Paulo como um todo, houve, de 1983 a 1986, um total de 950 casos notificados de AIDS. Acrescentando-se esses 54 casos desconhecidos do sistema de Vigilância Epidemiológica, tem-se um aumento de $5,7 \%$ no número de casos do Estado de São Paulo ${ }^{91}$.

O Centro de Referência e Treinamento-AIDS, da Secretaria do Estado da Saúde de Sāo Paulo, em seu Boletim Epidemiológico de novembro de $1992^{91}$, mostra que no período de 1983 a 1986 foram contabilizados 742 óbitos por AIDS. Com o acréscimo dos 54 que foram identificados pelo estudo tem-se 796 óbitos que representa um aumento de $7,3 \%$ no total de óbitos por AIDS.

A letalidade da doença, calculada pela relação número de óbitos pelo total de casos no periodo considerado também aumenta, passando de $78,1 \%$ para $79,3 \%$.

Dados do Ministério da Saúde ${ }^{67}$ indicam que de 1980 a 1986 foram diagnosticados e notificados 769 casos de AIDS no Município de São Paulo. Os achados deste estudo permitem informar que na realidade este dado é $7 \%$ maior ou seja, houve, no período 823 casos de AIDS na Cidade de São Paulo.

\section{2 - A identificação dos casos onde a causa básica da morte era uma doença diferente das selecionadas para o estudo}

A revisão dos atestados de óbito definidos como de interesse para o estudo permitiu, através do exame de àtestado por atestado, que se separassem também alguns com informações sugestivas de caso de AIDS. 
Entre as informaçōes sugestivas de AIDS estão as doenças reconhecidamente associadas a síndrome como o Sarcoma de Kaposi, a pneumocistose, a criptococose, a toxoplasmose cerebral, entre outras. Os atestados de óbito que continham essas patologias mas que não faziam menção de AIDS foram comparados com as informaçōes da vigilância epidemiológica. A tabela 9 mostra o número e a proporção de atestados desse grupo.

Algumas outras doenças, ainda que não reconhecidamente associadas, naquele momento, à AIDS, foram selecionadas como "possíveis casos". Estes foram comparados com os dados do SVE e comprovados, ou não, como casos notificados da síndrome.

Um terceiro grupo pode, ainda, ser caracterizado. Fazem parte deste aqueles atestados de óbito que só puderam ser incluídos no grupo de AIDS pelas informaçōes do sistema de vigilância. Assim, cada nome da lista de casos notificados foi checado com os atestados de óbito selecionados para este estudo. Este tipo de procedimento, bastante trabalhoso, permitiu que se corrigissem as informações referentes à mortalidade, do sistema de vigilância de AIDS. Assim, 53 atestados puderam ser recuperados por serem casos notificados, embora as causas mencionadas não fossem identificadas com a AIDS. Estas causas estão mencionadas nas tabelas 12 e 13 .

Além dos 53 atestados mencionados acima outros sete atestados foram considerados neste grupo, embora não fossem notificados como AIDS. Esses 7 atestados foram incluídos como casos de AIDS e analisados como tal por várias razōes, especificadas a seguir, embora em alguns não houvesse sequer menção de AIDS ou de doenças associadas a essa síndrome.

Esses sete casos tiveram como causa básica as seguintes patologias: abscesso cerebral; doença linfoproliferativa; estafilococia; pneumopatia infecciosa; pneumopatia intersticial; broncopneumonia e um caso de insuficiência cardiaca. 
Embora algumas dessas causas evidenciem uma provável infecção pelo HIV, após a comparação com os dados da notificação, não foram comprovados como caso de AIDS pelo menos como caso conhecido pelo SVE.

O caso cuja causa básica era insuficiência cardíaca apresentava menção de candidíase extensa de mucosa e meningoencefalite viral, que afastavam qualquer dúvida quanto a presunçāo da AIDS.

Informaçōes adicionais, obtidas posteriormente, permitiram identificar, entre esses sete casos, 3 que realmente se referiam a casos de AIDS. Foram comprovados como tal pela tamília, por dados da imprensa e por informaçōes do serviço de saúde que atendeu o paciente.

Os demais casos não puderam ser comprovados como casos de AIDS, mas foram incluídos neste grupo por que eram óbitos causados por doenças não bem especificadas no atestado de óbito e que, talvez por falta de tempo ou de acesso aos exames, não foi possível definir o diagnóstico de infecção pelo HIV. Assim, é possível que o caso de pneumonia intersticial deste estudo seja, na verdade, uma pneumonia por Pncumocystis carinii onde o agente não foi identificado. $\mathrm{O}$ mesmo pode ser dito $\mathrm{cm}$ relação à pneumonia e à broncopneumonia.

Da mesma forma, os atestados onde a causa básica informada era doença linfoproliferativa podem ocultar um quadro de linfoma, não identificado por falta de exames adequados c específicos.

Além da causa básica anotada ser uma causa presumível de ocorrer quando há infecção pelo HIV, outras informaçōes mencionadas no atestado de óbito sugerem a possibilidade de se tratar de um caso de AIDS, como por exemplo o estado civil e a ocupaçî́o. Desta forma, os sete casos eram indivíduos solteiros dois eram profissionais liberais, um professor universitário, um estudante, un comerciante c dois estilistas. É claro que a ocupaçāo não serve de indicador pari 
cuja soma dos pontos atinge um mínimo de 10 desde que haja a evidência laboratorial da infecção pelo HIV. Um teste é considerado positivo quando uma amostra de soro é repetidamente reativa em teste para pesquisa de anticorpos anti-HIV (ELISA, nor exemplo) e/ou é positivo quando submetida à testes de detecção do antígeno e/ou cultura positiva do agente.

Na presença de um resultado de teste positivo, a ocorrência de doenças indicativas de AIDS permite que se considere caso da doença desde que estas tenham sido diagnosticadas presuntivamente. As doenças indicativas de AIDS assim como os critérios sugeridos para diagnóstico presuntivo estão no anexo 3.

Pode se considerar caso de AIDS, ainda que não exista o teste ou seu resultado seja desconhecido, a ocorrência de doença indicativa de AIDS quando diagnosticada definitivamente e desde que outras causas de imunodeficiência sejam excluídas. O critério de diagnóstico definitivo, mais específico, está descrito no anexo 3, assim como as demais causas de imunodeficiência.

As várias mudanças no critério de caracterizaçāo de caso de AIDS confundem e alteram as estatísticas de incidência da doença. Já foram citados anteriormente estudos onde se mediu o aumento proporcional no número de casos após cada revisão da definição.

Ainda que mais sensivel, as definiçōes e critérios atuais só permitem um diagnóstico de AIDS com comprovaçāo laboratorial, ou através de testes para detectar o HIV ou anticorpos anti-HIV ou pela identificação de outros agentes de infecções oportunistas. A necessidade de exames complementares para a comprovação torna a identificação de um caso de AIDS muitas vezes impossível em locais onde nāo há acesso aos testes laboratoriais ou quando se trabalha com dados de mortalidade, como neste estudo.

Os critérios são claros. Ainda que haja menção de doenças indicativas de 
AIDS, sem um resultado positivo para o teste de HIV, estas doenças só podem servir como critério para a notificação de caso de AIDS quando confirmadas por exames específicos. Este é um dado que o atestado de óbito não provê. As causas mencionadas pelo médico que atendeu o indivíduo são anotadas como diagnóstico, porém se este foi, ou não, confirmado e através de qual exame se fez esta confirmação, é difícil saber apenas pelos dados do atestado, uma vez que não são preenchidos adequadamente.

A definição de caso é um dos problemas apontados como causa de subnotificação, principalmente por ser a AIDS uma doença recentemente introduzida em nosso meio. Outro motivo que contribui para a subnotificação de casos é a existência de um sistema de classificação para a infecção pelo HIV. Este, descrito no anexo 2, indica as possíveis evoluções clínicas, da fase de infecção à fase de doença e é utilizado como critério para caracterizar o início clínico da doença.

A existência desse critério e das definiçōes de caso podem confundir os profissionais, principalmente porque este último critério define o limite entre o estado de infeç̧ão e o de doença ativa, quando esta deve ser notificada. No entanto, os demais critérios, usados com finalidade de vigilância, apontam o que é um caso de AIDS passível de notificação.

Desta forma, pela nova definiçāo de casỏdo $C D C^{20}$, deve ser considerado caso, para fins de notificação, todo indivíduo soropositivo com contagem de linfócitos T4 menor aue 200 células por microlitro de sangue ou $14 \%$ deste tıpo de célula em relacão ao total de_linfócitos._ainda aue seia assintomático. No entanto, a classificação clínica considera caso de AIDS aquele indivíduo infectado que apresente sintomas e/ou sinais que se enquadrem no grupo IV da citada classificação (anexo 2).

As doenças descritas como indicativas de AIDS, pela definiçāo de caso, estão também incluídas no sistema de classificação de infeç̧ão, em categorias já 
consideradas como AIDS instalada (grupo IV subgrupos B, C ou D). Esta classificação, de uso eminentemente clínico, é utilizada pelos serviços de saúde para definir o momento de iniciar a terapêutica anti-viral. A liberação do medicamento aos pacientes, sem ônus, é facultada aos casos inscritos em hospitais públicos, que atingem o grupo IV do citado sistema de classificação da infecção e apenas mediante a notificação do caso ao SVE. Esta medida fez com que o número de casos notificados aumentasse concomitantemente ao aumento do número de tratamentoş comprados pelo Ministério da Saúde.

Um outro fator que aumenta a sub-notificação dos casos de AIDS é o sigilo médico. Muitas vezes o paciente não deseja ter revelada sua condição de portador do vírus, ou de doente, e o médico, corretamente, respeita essa vontade. Porém, em determinadas circunstâncias e apesar do desejo do paciente, o médico pode, e deve, romper esse sigilo. Assim, quando a omissão sobre a condição de portador do vírus coloca em risco a vida de terceiros e também para notificar as autoridades sanitárias e preencher, adequadamente, o atestado de óbito, o médico deve romper esse sigilo.

Ainda que vários mecanismos atuem pressionando o médico a não informar, esta conivência com a vontade do paciente ou da família na omissão das informações ocorre em detrimento das estatísticas de saúde e fortalece o estigma da doença.

Algumas vezes o profïssional de saúde deixa de notificar o caso por não saber como, ou quando, fazê-lo. Ainda que a vigilância seja realizada de forma ativa em nosso meio, muitos médicos atendem em seus consultórios particulares e nāo notificam às autoridades sanitárias. A subnotificação ocorre não apenas em relação à AIDS mas também às demais doenças infecciosas.

Uma pesquisa realizada entre médicos da Austrália identificou os motivos para a não notificação dos casos, entre eles as dificuldades de procedimento para 
efetuar a notificação, o não retorno das informaçōes, as complicaçōes inerentes à definição de caso e a confiabilidade desta informação 59 .

Os 54 casos descobertos por este estudo, que não haviam sido notificados, foram encaminhados ao serviço de vigilância epidemiológica para que se procedesse a notificação, tanto do caso como do óbito, e para que com essa inclusão fossem corrigidas as estatísticas tanto de morbidade como de mortalidade por AIDS.

\section{A NOTIFICAÇÃO DOS ÓBITOS POR AIDS}

A metodologia de revisão dos atestados de óbito possibilita a identificação daquelas declaraçōes onde a AIDS é mencionada mas não é a causa básica. Deve se ressaltar que um indivíduo com AIDS não morre, necessariamente, devido a esta doença. Estas informações também podem ser avaliadas através da revisão dos atestados de óbito.

Dos 359 casos identificados como AIDS através deste estudo, 54 eram casos da doença cuja informação só pode ser obtida por este estudo. Além desses, 125 não haviam sido informados como óbito ao sistema de vigilância epidemiológica.

Entre esses 125, alguns podem, também, se referir a casos não notificados. A diferença de número entre os dois, 54 subnotificação de caso e 125 de óbito, se explica por vários motivos. Entre estes, a morte por doenças não identificadas à AIDS, a omissão intencional da causa básica da morte quando esta é a síndrome da imunodeficiência adquirida ou uma falha no tluxo de troca de informaçōes 
entre os sistemas de mortalidade e de vigilância.

As causas mencionadas nos atestados-são apresentadas na tabela 13 , de acordo com a ocorrência de notificação do óbito ao Serviço de Vigilância Epidemiológica da Secretaria do Estado da Saúde de São Paulo.

TABELA 13 - Obitos por AIDS em indivíduos do sexo masculino, de 20 a 49 anos, segundo causa básica e notificação do óbito, Município de São Paulo, 1983-1986.

\begin{tabular}{|c|c|c|c|c|c|c|}
\hline \multirow{3}{*}{ Causa básica } & \multicolumn{4}{|c|}{ óbitos } & \multirow{2}{*}{\multicolumn{2}{|c|}{ TOTAL }} \\
\hline & \multicolumn{2}{|c|}{ notificados } & \multicolumn{2}{|c|}{$\begin{array}{c}\text { não } \\
\text { notificados }\end{array}$} & & \\
\hline & No & $\%$ & No & $\%$ & No & $\%$ \\
\hline AIDS & 114 & 65,1 & 61 & 34,9 & 175 & 100,0 \\
\hline Imunodef. & 1 & 16,7 & 5 & 83,3 & 6 & 100,0 \\
\hline Tuberculose & 24 & 77,4 & 7 & 22,6 & 31 & 100,0 \\
\hline Pneumonia,BCP & 20 & 87,0 & 3 & 13,0 & 23 & 100,0 \\
\hline Pneumocistose & 12 & 60,0 & 8 & 40,0 & 20 & 100,0 \\
\hline Sarcoma de Kaposi & 7 & 58,3 & 5 & 41,7 & 12 & 100,0 \\
\hline Criptococose & 6 & 50,0 & 6 & 50,0 & 12 & 100,0 \\
\hline Absc.Intracraneano & 7 & 70,0 & 3 & 30,0 & 10 & 100,0 \\
\hline D.Sist. Nervoso & 5 & 50,0 & 5 & 50,0 & 10 & 100,0 \\
\hline Toxoplasmose & 5 & 83,3 & 1 & 16.7 & 6 & 100,0 \\
\hline Linfoma,linfossarcoma & 3 & 75,0 & 1 & 25,0 & 4 & 100,0 \\
\hline Moniliase & 1 & 33,3 & 2 & 66,7 & 3 & 100,0 \\
\hline Pneumonia alveolar & 2 & 66,7 & 1 & 33,3 & 3 & 100,0 \\
\hline Todas demais & 27 & 61,4 & 17 & 38,6 & 44 & 100,0 \\
\hline TOTAL & 234 & 65,2 & 125 & 34,8 & 359 & 100,0 \\
\hline
\end{tabular}

Em estudo sobre a confiabilidade dos dados de mortalidade por AIDS no Estado de São Paulo, em 1984, verificou-se que a AIDS só foi mencionada em 
$47,5 \%$ dos atestados referentes a casos notificados da doença, dentre aqueles que puderam ser recuperados 21 .

O desconhecimento sobre o número de casos de AIDS que foram a óbito, reduz, artificialmente, a letalidade da doença. Por este motivo o sistema de vigilância coleta informaçōes sobre ambos os dados.

É importante salientar que casos que não foram notificados no momento do diagnóstico, nos serviços de saúde, terão menor chance de o serem pelo atestado de óbito, uma vez que vários outros fatores atuam para a omissão da AIDS na parte médica da declaração de óbito.

O principal motivo de omissão da AIDS como a verdadeira causa de morte, identificado por um estudo realizado no Canadá, e com certeza presente também em nosso meio, é a "proteçāo da família" 47 , devido a imagem estigmatizada desta doença. Desde seu aparecimento sempre esteve fortemente ligada a reações preconceituosas, tanto que já foi denominada de "peste gay".

A AIDS, por sua maneira de transmissāo, sexual e via sangüínea por utilização de droga intravenosa, cria, em uma pessoa doente, a identificação, mesmo que não verdadeira, com um desses grupos. $O$ individuo infectado ou doente se sente marginalizado pelos demais, mesmo dentro de seu grupo e este fato torna suas relações pessoais e sua vida bastante difíceis. Em função desta estigmatização, grupos se organizaram para diminuir a rejeiçāo da sociedade aos infectados e doentes, difundir conhecimentos sobre a doença e para ajudar os que não têm condiçōes de tratamento. Estas organizações_não-governamentais, presentes hoje no mundo inteiro e que oferecem desde assessoria jurídica até assistência médica domiciliar, constituem a primeira resposta da sociedade civil às políticas de controle da epidemia.

O estigma em torno de certas doenças, mais prevalentes em determinadas áreas, é também a causa da omissão de outras patologias como causa de morte. 
O alcoolismo, por exemplo, era considerado até 1984 , na Inglaterra, envenenamento e portanto mortes devido à esta causa eram sujeitas a investigação. Este procedimento levava à omissão desta doença como causa de morte para evitar transtornos à família dos indivíduos que faleciam em conseqüência do alcoolismo ${ }^{48}$.

Em um estudo onde foram avaliados óbitos de veteranos do Exército americano, POLLOCK e colaboradores ${ }^{80}$ (1987), submeteram à analise de médicos, 426 prontuários, de casos desconhecidos e que haviam falecido, para que, com os dados disponiveis, preenchessem uma nova declaração de óbito. Obtiveram 133 óbitos por causas relacionadas ao alcoolismo, 6 vezes mais do que havia sido anotado no atestado verdadeiro, preenchido no momento do óbito.

O suicídio é outra causa bastante estigmatizada. $\mathrm{KING}^{48}(1989)$ ressalta a importância de determinadas características legais como obstáculo à obtenção de informaçōes verdadeiras sobre a causa de morte. Na Inglaterra o seguro de vida só é pago integralmente se o óbito aconteceu por morte natural ou acidente. Desta forma um atestado que contenha suicídio como causa de morte pode levar a familia a perder parte ou todo o seguro.

O câncer é uma das mais freqüentes causas de morte de adultos, e também é uma informação das mais confiáveis. Porém algumas vezes deixa de ser mencionada nos atestados, como verificou BENAVIDES e colaboradores ${ }^{8}(1989)$, em trabalho revisando atestados de óbito de Valência, Espanha, referem que em 30 atestados de óbito devido à câncer esta causa não estava anotada, tendo sido reclassificados após o estudo. A mortalidade por câncer não foi declarada em $6,1 \%$ dos casos onde este grupo de patologia era a verdadeira causa da morte.

Ainda que a omissão de doenças estigmatizadas quando estas são causa de morte ocorra na maioria dos países, um esforço deve ser feito para que os médicos entendam a importância do preenchimento completo, e correto, do atestado de óbito. 
A educação médica é fundamental e tem como finalidade informar os objetivos e usos das informações de vigilância e de mortalidade, assim como o esclarecimento sobre as conseqüências resultantes do uso de dados falsos ou incompletos no planejamento e na avaliação dos programas de saúde.

Alguns autores propõem, como medida para assegurar a inviolabilidade do dado médico, um atestado em duas partes, destacáveis. Assim este documento teria uma parte com finalidade legal e outra com fins médicos e epidemiológicos. Esta parte médica seria retida no ato do registro e a família ficaria com a parte de interesse legal ${ }^{15,48}$.

\section{CONCLUSÕES E CONSIDERAÇÕES FINAIS}

Os resultados aqui apresentados corroboram os dados de estudos internacionais onde os óbitos por AIDS, no sexo masculino, manifestaram-se predominantemente em indivíduos na faixa etária de 30 a 39 anos (38,7\%) e solteiros $(50,2 \%)$. O coeficiente de mortalidade por AIDS e por idade foi de 6,0 por 100000 indivíduos do sexo masculino, na faixa de 30 a 34 anos. Os coeficientes de mortalidade aumentam de acordo com a idade e com o tempo.

Esses óbitos ocorreram, em sua maioria, em hospitais $(76,7 \%)$ sendo que pode se destacar a grande participação de hospitais públicos, que atendem uma maior demanda, principalmente, em vista do elevado custo do tratamento da AIDS.

Ainda que em $10 \%$ dos atestados a informação sobre ocupação fosse ignorada, as categorias profissionais mais freqüentes, neste estudo, foram os 
trabalhadores braçais $(12,5 \%)$ e os inativos $(11,4 \%)$.

Em relação ao grau de instrução, em grande parte dos atestados estudados, esse dado foi ignorado $(40,7 \%)$, quase metade dos indivíduos tinha educação fundamental e apenas $4,9 \%$ tinha nível superior.

As causas de morte mais freqüentes foram as pneumonias e broncopneumonia $(39,07 \%)$, o suicídio $(20,45 \%)$ e a tuberculose $(17,80 \%)$.

Do total de 4023 atestados selecionados, 359 (8,9\%) eram casos de AIDS, e desses, $85 \%$ eram casos notificados. A menção da síndrome, ou apenas de imunodeficiência, como causa básica ocorreu em 50,4\% dos atestados desse grupo.

A tuberculose foi a causa básica mais citada $(8,6 \%)$ nos atestados de indivíduos com AIDS seguida pelas pneumonias e broncopneumonia, em 6,4\%, pela pneumocitose em $5,6 \%$ e pelo sarcoma de Kaposi e pela criptococose em $3,4 \%$ das declarações.

A AIDS foi mencionada, também, em $22,5 \%$ dos atestados, embora, segundo as regras de codificação da causa básica, nestas declaraçōes a AIDS não foi selecionada como tal.

Em 37 atestados, doenças indicativas de AIDS foram a causa básica, e destes, 70\% eram casos notificados de AIDS. As demais doenças foram mencionadas, como causa básica do óbito, em 60 casos dos quais $88,3 \%$ eram notificados. Estes casos só puderam ser recuperados pela busca nominal dos atestados de óbito e, aqueles não notificados foram enviados ao serviço de vigilância epidemiológica para que se efetuasse a notificação do caso e/ou do óbito.

Esse número de casos, não computados pelo sistema, implica no aumento da prevalência e da letalidade da AIDS em nosso meio. 
Os casos identificados por este estudo permitem um aumento, nos dados do CVE, de 5,7\% no total de casos de AIDS, do Município de São Paulo, para o período de 1983 a 1986. É possível, também uma correção no número de óbitos, da ordem de $7,3 \%$ e, conseqüentemente, um aumento da letalidade da doença que passa, de $78,1 \%$ para $79,3 \%$.

As informaçōes obtidas pela revisão dos atestados de óbito contribuem para o entendimento da história da epidemia de AIDS em nosso País. Embora esses dados se limitem ao estudo da mortalidade pela síndrome, permitem que sejam levantadas uma série de questões importantes e que não foram privilegiadas neste trabalho.

O fato da epidemia ter se iniciado, pelo menos nas Américas, no grupo de homossexuais de um estrato social mais elevado, proporcionou uma atenção à doença que talvez não ocorresse se ela ficasse limitada aos países da África. A AIDS sempre esteve nos meios de comunicação e cada vez que atingia uma pessoa pública, algumas questões relacionadas à doença passavam a ser discutidas e pesquisadas.

Essa discussão abrange a cidadania, a identidade sexual, as relações interpessoais, aborda o uso de drogas injetáveis e os problema sociais que a epidemia determina em países subdesenvolvidos além, é claro, das questões diretamente ligadas à área da saúde como o controle do sangue, a prevalência de infectados na população, entre outros.

O conhecimento dos aspectos epidemiológicos da doença permite que as ações de controle sejam melhor direcionadas. Desta forma os mecanismos de prevenção devem ser amplamente divulgados, de forma direta, clara e completa. Para que isso ocorra as Arampanhas , devem atingir a população certa, de forma adequada e isto só é possível através das informações coletadas a nível de vigilância epidemiológica ou pelos dados de mortalidade. 


\section{REFERÊNCIAS BIBLIOGRÁFICAS}




\section{REFERÊNCIAS BIBLIOGRÁFICAS}

1 AIDS:poor man's plague. Economist,21 set.p:21-4,1991.

2 AMATO NETO, V. et al. Síndrome da imunodeficiência adquirida (AIDS): descrição do primeiro caso autóctone do Brasil e estudo imunológico. Rev.paul.Med,101:165-8,1983.

3 ANDERSON, R.M. \& MAY,R.M. Epidemiological parameters of HIV transmission. Nature,333(6173):514-9,1988.

4 ANKRAH, E.M. AIDS: methodological problems in studying its prevention and spread. Soc.Sci.Med.,29:265-76, 1989.

5 ARRUDA MATTOS, A. L. Anatomia patológica na síndrome da imunodeficiência adquirida (AIDS). São Paulo,1985. |Dissertação de Mestrado- Escola Paulista de Medicinal

6 BARBIERI, D.D.et al. Mudanças do perfil da AIDS no Município de São Paulo (1985- 1991). REAIDS,1(2):6-7, 1992.

7 BARRE-SINOUSSI, F. et al. Isolation of a T-Lymphotropic retrovirus from a patient at risk for acquired immune deficiency syndrome (AIDS). Science, 220:868-71,1983.

8 BENAVIDES, F. G. et al.Quality of death certificates in Valencia, Spain. Amer. J. publ. Hlth,79:1352-4,1979.

9 BERQUÓ, E.S. et al. Bioestatística. São Paulo, EPU, 1981. 
10 BIRD, A.G. "AIDS" without HIV: fire without smoke Brit.med.J.,305:325-6,1992.

11 BOBBY, J.J.et al. AIDS deaths in the U.K.: how complete are the figures? Publ. Hlth,102:519-24,1988.

12 BRIGIDO, L.F.M. O HIV e o sistema imune. Ciênc. e Cult., 42:530-36,1990.

13 BUEHLER, J.W et al. Reporting of AIDS: tracking HIV morbidity and mortality. J.Amer. med. Ass.,262:2896-97,1989

14 BUEHLER, J.W.et al. Impact of the human immunodeficiency virus epidemic on mortality trends in young men, United States. Amer. J. publ. Hlth, 80:1080-6,1990.

15 CARTER, J.R. The problematic death certificate. N. Engl. J. Med..313:1285-6,1985.

16 CENTERS FOR DISEASE CONTROL.Update on acquired immune deficiency syndrome (AIDS): United States. Morb. Mort. wkly Rep.,31:507-8,1982

17 CENTERS FOR DISEASE CONTROL. Revision of the CDC surveillance case definition for acquired immunodeficiency syndrome. Morb. Mort. wkly Rep., 36 (Supll.1) 1987.

18 CENTERS FOR DISEASE CONTROL. Human immunodeficiency virus (HIV) infection codes official authorized addendum ICD-9-CM ( revision $\mathrm{n}^{\circ} 1$ ). Morb. Mort. wkly Rep., 36 (Suppll 7) 1987.

19 CENTERS FOR DISEASE CONTROL. AIDS and human immunodeficiency virus infection in the United States: 1988 Update. Morb. Mort. wkly Rep., 38 (Suppll) 1989.

20 CENTERS FOR DISEASE CONTROL. 1993 revised classification system for HIV infection and expanded surveillance case definition for AIDS among adolescents and adults. Morb. Mort. wkly Rep., 41:1-19,1992.

21 CENTRO DA ORGANIZAÇÃO MUNDIAL DA SAÚDE PARA A CLASSIFICAÇĀO DE DOENÇAS EM PORTUGUÊS. A AIDS/SIDA : as estatísticas de mortalidade como fonte de informaçōes. São Paulo, 1990.(Série de Divulgação n_o6)

22 CENTRO DA ORGANIZAÇÃO MUNDIAL DA SAÚdE PARA A CLASSIFICAÇÃO DE DOENÇAS EM PORTUGUÊS. Decrição de novas doenças. Boletim.4(1) 1983. 
23 COFFIN, J. et al. Human immunodeficiency viruses. Science, 232:697,1986.

24 COHEN, J Debate on AIDS origin: Rolling Stone weighs in. Science,255: 1505,1992

25 COLEBUNDERS, R.L. \& HEYWARD, W.L. Surveillance of AIDS and HIV infection, opportunities and Challenges. Hith Policy,15:1-11,1990.

26 CONWAY, G.A. et al. Underreporting of AIDS cases in South Carolina, 1986 and 1987.J. Amer. med. Ass., 262: 2859-63,1989

27 CORBITT, G. et al. HIV in Manchester, 1959. Lancet, 336: 51, 1990.

28 CORTES, E. et al. HIV-1, HIV-2 and HTLV-1 infection in high risk groups in Brazil. N.Engl. J. Med.,320:953-8,1989

29 CURRAN, J.W. et al. Epidemiology of HIV infection and AIDS in the United States . Science,239:610-6,1988.

30 DOMINGUES, C.S.B. et al. Vigilância epidemiológica $X$ subnotificação de casos.[Apresentado no $2^{\circ}$ Congresso Brasileiro de Epidemiologia, Belo Horizonte, MG, 1992]

31 DONOVAN, J.W. Inconsistencies in statistcs of death from AIDS. Med. $J$. Austr.,154:90-2,1991.

32 DUFOORT, G et al. No clinical signs 14 years after HIV-2 transmission via blood transfusion. Lancet,2:510,1988.

33 FAUCI, A.S. The human immunodeficiency virus: infectivity and mechanisms of pathogenesis. Science, 239:617-22,1988.

34 FLANDRE, P. \& VALLERON, A.J. Impact démographique de la mortalité par SIDA en France en 1990 : le SIDA devant le suicide et proche des accidents de la circulation. Rev. Epidém. Santé Publ..36:196-201,1988.

35 FONSECA, L.A.M. \& PEIXINHO, Z.F. Epidemiologia da AIDS. Ciên. $e$ Cult, 42:523-9,1990.

36 FR I E DMAN-KIEN, A. et al. Kaposi's Sarcoma and Pneumocystis pneumonia among homosexual men- New York City and Califórnia. Morb. Mort. wkly Rep., 30:305-8,1981.

37 FROLAND, S.S. et al. HIV-1 Infection in Norwegian family before 1970. Lancet,1:1344-5,1988. 
38 GALLO, R.C. et al. Frequent detection and isolation of cytopathic retroviruses (HTLV-III) from patients with AIDS and at risk for AIDS. Science, 224:500-3,1984.

39 GONDA. M.A. The natural history of AIDS. Natur. Hist., 5:778-81,1986

40 GOTLIEB, M.S. et al. Pneumocystis Pneumonia-Los Angeles. Morb. Mort. wkly Rep.,30:250-2,1981.

41 HARDY, A. M. et al. Reviews of death certificates to assess completeness of AIDS case reporting. Publ. Hlth Rep.,102:386-91,1987.

42 HERZOG, A.A. et al. A retrospective death certificate study of AIDS and AIDS-related conditions in Ohio:1984-1986.J. Ohio State Med.Ass. 85:985-9, 1989.

43 HESSOL, N. A. et al. Prevalence, incidence, and progression of human immuno deficiency virus infection in homosexual ans bisexual men in hepatitis $\mathrm{B}$ vaccine trials, 1978-1988. Amer.J. Epidem.,130:1167-75,1989.

44 HESSOL, N. A.et al. Impact of HIV infection on mortality and accuracy of AIDS reporting on death certificates. Amer. J. publ. Hlth,82:561-4,1992.

45 HUMINER, D et al. AIDS in the pre-AIDS era. Rev.infect. Dis.,9:1102-8,1987.

46 IMAGAWA, D. et al. Human immunodeficiency virus type I infection in homosexual men who remain seronegative for prolonged periods. N.Engl.J.Med..320:1458-62, 1989.

47 JOHNSON, R.J.et al. Using death certificates to estimate the completeness of AIDS case reporting in Ontário in 1985-1987. Canad. med. Ass.J.,141:537-40,1989.

48 KING, M.B. AIDS on the death certificate: the final stigma. Brit. med. J.,298:734-6,1989.

49 KRISTAL, A.R. The impact of the acquired immunodeficiency syndrome on patterns of premature death in New York City. J. Amer. med. Ass.,225:2306-10,1986.

50 KYLE, W.S. Simian retroviruses, poliovaccine, and origin of AIDS. Lancet,339:600-1,1992.

51 LAUMANN, E.O. et al. Monitoring the AIDS epidemic in the United States: a network approach. Science, 244:1186-9,1989. 
52 LAURENCE, J. et al. Acquired immunodeficiency without evidence of infection with human immunodeficiency virus types 1 and 2. Lancet,340:273-4,1992.

53 LAURENTI, R. et al. Estatísticas de saúde. São Paulo, EPU/EDUSP, 1985.

54 LIFSON, A.R. et al. The natural history of human immunodeficiency virus infection. J. infect. Dis., 158:1360-7,1988.

55 LIRA, M. et al. AIDS and death statistics: prompt access to information and the redution of underregistration. [ Apresentado na "8th International Conference on AIDS/ 3 rd STD World Congress -Amesterdã , Holanda, 1992.]

LUNA, E. et al. Mortalidade por AIDS no Município de Sāo Paulo .São Paulo, Centro de Epidemiologia, Pesquisa e Informação Prefeitura do Município de São Paulo,1991. [mimeografado]

57 MARZUK, P.M. et al. Increased risk of suicide in persons with AIDS. J. Amer. med. Ass., 259:1333-7,1988.

58 MATIDA, L.H. Avaliação do sistema de informaçāo de tuberculose e AIDS no Município de sāo Paulo, 1990. [Apresentado no $2^{\circ}$ Congresso Brasileiro de Epidemiologia, Belo Horizonte, MG, 1992]

59 Mc ANULTY, J.M et al. Underreporting of AIDS, New South Wales, 1988- 1989. Med. J. Austr: 156:452-5,1992.

60 McCORMICK, A. Trends in mortality statistics in England and Wales with particular reference to AIDS from 1984 to april 1987. Brit. med. J., 296:1289-92,1988.

61 McCORMICK, A Estimating the size of the HIV Epidemic by using mortality data. Phil.Trans. R.Soc. Lond., 325:163-73,1989.

62 MINISTÉRIO DA SAÚDE. Legislação brasileira sobre a sindrome de imunodeficiência adquirida-SIDA/AIDS. Brasilia, Centro de Documentação do Ministério da Sáude, 1986.

63 MINISTÉRIO DA SAÚDE. Classificação brasileira de ocupações para o subsistema de informações sobre mortalidade. Brasilía , Centro de Documentação, 1987.

64 MINISTÉRIO DA SAÚDE. Definição de caso de AIDS em adultos para fins de vigilância epidemiológica. AIDS Bol. epidem.,2 (8) 1989

65 MINISTÉRIO DA SAÚdE. Programa Nacional de Doenças Sexualmente Transmissiveis/ AIDS. AIDS Bol. epidem., 5 ( 2) 1992 
66 MINISTÉRIO DA SAÚDE. Programa Nacional de Doenças Sexualmente Transmissíveis/ AIDS. AIDS Bol. epidem., 5 (4) 1992.

67 MINISTÉRIO DA SAÚDE. Programa Nacional de Doenças Sexualmente Transmissíveis/ AIDS. AIDS Bol. epidem., 5 (7) 1992.

68 MINISTÉRIO DA SAÚDE. Programa Nacional de Doenças Sexualmente Transmissíveis/ AIDS. Revisão da definição nacional do caso de AIDS em adultos. Brasilia, 1992.

69 - MORIYAMA, I.M. Problems in measurement of accuracy of cause of death statistics. Amer.J.pubLHlth,79:1349- 50,1989.

70 MORRISON, F. AIDS: current definitions, classification and codes. Geneva, WHO Consultation on the classification of HIV infections for ICD-10. 1988 (WHO/DES/SFI/WG/88.4)

71 NAHMIAS, A.J. et al. Evidence for human infection with an HTLV-III/LAV -like virus in Central Africa, 1959. Lancet,1:1279, 1986.

I2 NARAIN, J.P.et al. HIV-associated tuberculosis in developing countries: epidemiology and strategies for prevention. Geneva; World Health Organization,1992 (WHO/TB/92.166)

73 ORGANIZAÇĀO MUNDIAL DA SAÚDE. Manual da classificação internacional de doenças, lesões e causas de óbito: $9^{a}$ revisāo, 1975 .São Paulo, Centro Brasileiro para a Classificação de Doenças, 1978

74 ORGANIZAÇÃO MUNDIAL DA SAÚDE. Acquired immunodeficiency syndrome (AIDS) Global Data. Wkly epidem. Rec.,67:201-4 ,1992

75 ORGANIZAÇÃO PANAMERICANA DE LA SALUD. Grupo de Trabajo sobre Definición de Casos de SIDA. Bol.Epidem.,10 (4): 9-11, 1990.

76 ORGANIZAÇÃO PANAMERICANA DE LA SALUD. EI SIDA en América Latina y Caribe: situación actual. Bol. Epidem.,13(1): 1-8, 1992

77 ORGANIZAÇĀO PANAMERICANA DE LA SALUD. Vigilancia del SIDA en las Américas. Bol. Epidenı.,13(2):15,1992

78 O PACIENTE zero. Clä-Goodyear,(maio/jun.), 1988.

79 PIOT, P. et al. AIDS:an international perspective.Science, 239:573-9.1988.

80 POLLOCK, D.A. et al. Underreporting of alcohol-related mortality on death certificates of young US Army veterans. J. Amer: med. Ass., 258:345-8,1987. 
81 POPOVIC, M. et al. Detection, isolation and continuous production of cytopathic retroviruses (HTLV-III) from patients with AIDS and Pre-AIDS. Science, 224:497-500, 1984.

82 PREFEITURA DO MUNICÍPIO DE SĀO PAULO.PRO-AIM Programa de Aprimoramento das Informações de Mortalidade no Município de São Paulo. (6), 1992.

83 PREFEITURA DO MUNICÍPIO DE SÃO PAULO.PRO-AIM Programa de Aprimoramento das Informações de Mortalidade no Município de São Paulo.(Ed. Esp.), 1992.

84 PREFEITURA DO MUNICÍPIO DE SÃO PAULO.PRO-AIM Programa de Aprimoramentodas Informaçōes de Mortalidade no Município de São Paulo. (7), 1992.

85, QUINN, T.C.et al. AIDS in Africa: an epidemiologic paradigm. Science, 234:955-63,1986.

86 RANKI, A et al. Long-latency precedes overt seroconversion in sexually transmitted human-immunodeficiency-virus infection. Lancet,2:589-93,1987.

87 RIEDER, H.L. et al. Tuberculosis and acquired immunodeficiency syndrome Florida. Arch. Intern. Med.,149:1268-73,1989.

88 RUTHERFORD, G.W.et al. Course of HIV-I infection in a cohort of homosexual and bisexual men: an 11 year follow up study. Brit. med.J., 310:1183-8,1990 .

89 SECRETARIA DE ESTADO DA SAÚDE. Centro de Vigilância Epidemiológica. AIDS no Estado de São Paulo. Bol. Epidem. (jun.) 1992.

90 SECRETARIA DE ESTADO DA SAÚDE. Centro de Vigilância Epidemiológica. AIDS no Estado de São Paulo.Bol.Epidem. (out.) 1992.

91 SECRETARIA DE ESTADO DA SAÚDE. Centro de Vigilância Epidemiológica. AIDS no Estado de Sāo Paulo. Bol. Epidem. (nov.) 1992.

92 SELIK, R.M. et al. Impact of the 1987 revision of the case definition of acquired immunodeficiency syndrome in the United States. J. Acquir:Immunodefic. Syndr.,3:73-82,1990.

93 SMITH, T.F. et al. The philogenetic history of immunodeficiency viruses. Nature, 333:573-5. 1988. 
94 STEVENS, C.E. et al. Human T-cell lymphotrophic virus type III infection in a cohort of homossexual men in New Yotk City. J.Amer.med. Ass., 255:2167-72,1986.

95 STONEBURNER, R.Let al. Increase in pneumonia mortality among young adults and the HIV epidemic -New York City, United States. Morb. Mort.wkly Rep., 37:593-6,1988.

96 THACKER, S.B.\& BERKELMAN, R.L. Public health surveillance in the United States. Epidemiol. Rev., 10:164-90,1988.

97 VERONESI,R. et al. Presença do HIV-1 e HIV-2 no Brasil. perspectivas epidemiológicas. Rev.bras.Med.,46:127-30, 1989.

98 WILLIAMS, G. et al. AIDS in 1959? Lancet, 2:1136,1983.

99 WINKELSTEIN, Jr. W. et al. The San francisco men's health Study : III Redution in human immunodeficiency virus transmission among homosexual/bisexual men, 1982-1986. Amer. J. publ. Hlth , 76:685-9, 1987. 
ANEXOS 


\section{ANEXO 1}

\section{A DEFINIÇĀO DE CASO DE AIDS DO "CENTERS FOR DISEASE CONTROL" revisão de $1987^{17}$}

Esta definiçāo de caso, proposta com finalidades de vigilância epidemiológica, baseia-se em exames laboratoriais de identificação do HIV. Pela especificidade da definição optou-se por uma apresentação resumida, apenas para ilustrar os pontos comentados no texto.

\section{I- Sem evidência de infeç̧ũo pelo HIV}

Nos casos onde o teste não foi realizado ou o resultado é inconclusivo:

- afastadas quaisquer das causas de imunodeficiência listadas no item A, abaixo, entāo

- qualquer doença citado no item B indica caso de AIDS desde que o diagnóstico seja realizado por métodos diagnósticos definitivos para doenças indicativas de AIDS (ver anexo 3-item 3, página A-14).

A) Causas de imunodeficiência que desqualificam doenças como indicativas de AIDS quando não houver comprovação laboratorial de infecção pelo HIV :

- Terapia com corticóide por tempo prolongado ou alta dosagem ou outra terapia imunossupressiva/ citotóxica efetuada em período menor que 3 meses antes do aparecimento da doença que indica AIDS.

- Qualquer das seguintes doenças diagnosticadas em menos de 3 meses depois do diagnóstico da doença indicadora de AIDS: doença de Hodgkin, linfoma não-Hodgkin, leucemia linfocítica, mieloma múltiplo, ou qualquer outro tipo de câncer de tecido linforreticular ou histiocítico, ou linfadenopatia angioimunoblástico. 
- Síndrome de imunodeficiência genética ou adquirida, não condizente com infeç̧ão pelo HIV, como hipogamaglobulinemia.

B) Doenças indicativas de AIDS quando diagnosticadas de forma definitiva (ver anexo 3 - item 3, página A-14):

- Candidíase do esôfago, traquéia, brônquios ou pulmões;

- Criptococose extrapulmonar;

- Criptosporidíase com diarréia por mais de 1 mês;

- Citomegalovirose em qualquer órgão que não o fígado, baço ou linfonódios, em pacientes com mais de 1 mês de idade;

- Doença pelo Micobacterüum avium ou M. kansasii, disseminada, em outros locais ou além do acometimento dos pulmões, pele, linfonódios cervicais ou hilares.

- Infecção pelo herpes simples causando úlcera mucocutânea que persiste por mais de 1 mês, ou bronquite, pneumonite ou esofagite afetando paciente com mais de 1 mês de idade;

- Leucoencefalopatia multifocal progressiva;

- Linfoma do cérebro (primário) afetando pacientes com menos de 60 anos de idade;

- Pneumonia linfoide intersticial e/ou hiperplasia linfóide pulmonar afetando paciente com menos de 13 anos de idade;

- Pneumonia por Pneumocystis carinii ;

- Sarcoma de Kaposi afetando paciente com menos de 60 anos de idade;

- Toxoplasmose do cérebro afetando pacientes com mais de 1 mês de idade. 


\section{II- Com evidências laboratoriais de infecção pelo HIV}

Independente da presença de qualquer outra causa de imunodeficiência, quando houver evidências laboratoriais de infecção pelo HIV, qualquer doença listada no item B, acima, assim como as seguintes patologias (listadas em II-A ou II-B), indicam diagnóstico de AIDS:

II-A - Doenças indicadoras de AIDS quando diagnosticadas de forma definitiva (ver anexo 3 - item 3, página A-14):

- infeç̧ão bacteriana ,múltipla ou recorrente (qualquer combinação de pelo menos duas, em um periodo de 2 anos), dos tipos abaixo listados, afetando menores de 13 anos de idade: meningite, infecção óssea ou articular, abscesso em órgão interno ou na cavidade corporal (excluindo otite média ou abscesso de pele ou de mucosa), causados por Haemophilus, Streptococcus (incluindo pneumococos) ou outras bacterias piogênicas.

- coccidioidiomicose disseminada (em local que não, ou além do, pulmões e linfonódios cervicais e hilares);

- encefalopatia por HIV;

- histoplasmose disseminada (em local que não, ou além dos, pulmões e linfonódios cervicais e hilares);

- isosporiáse com diarréia persistindo por mais de um mês;

- Sarcoma de Kaposi em qualquer idade;

- linfoma primário do cérebro, em pessoas de qualquer idade;

- outros linfomas não-Hodgkins ou de células B ou de fenótipo imunológico desconhecido;

- qualquer micobacteriose causada por outras micobactérias que não a M.tuberculosis, disseminada (em local que não, ou além dos, pulmões, pele ou linfonódios cervicais e hilares);

- doença causada por M.tuberculosis, extrapulmonar (envolvendo pelo menos um local além dos pulmōes, independente se há envolvimento pulmonar);

- scpticemia por Salmonella;

- "wasting syndrome" - perda de peso; 


\section{II-B - Doenças indicativas de AIDS quando diagnosticadas de forma presuntiva (anexo 3 -item 4,página A-14):}

Nota : dado a importância desses quadros, as doenças indicativas de AIDS, devem ser diagnosticadas de forma definitiva, especialmente quando a terapêutica a ser utilizada pode levar a efeitos colaterais sérios ou quando, por qualquer razão, há necessidade do diagnóstico definitivo.

- candidíase do esôfago;

- retinite por citomegalovírus com perda de visão;

- Sarcoma de Kaposi;

- Pneumonia linfóide intersticial e/ou hiperplasia linfóide pulmonar afetando criança menor de 13 anos;

- doença causada por micobacteria disseminada (envolvendo pelo menos uma localização além dos pulmōes, pele e linfonódios cervicais e hilares);

- Pneumonia por Pneumocystis carinii :

- Toxoplasmose do cérebro afetando um paciente com mais de 1 mês de idade;

\section{III- Com evidências laboratoriais contrárias à infecção pelo HIV}

Com resultados de testes negativos para o HIV, o diagnóstico da AIDS com finalidades de vigilância epidemiológica pode ser feito quando:

A- todas as demais causas de imunodeficiência listadas no item I -A forem excluidas e

B- o paciente apresenta :

- Pneumonia por Pneumocystis carinii diagnosticada por método definitivo ou

- qualquer outra doença indicativa de AIDS listada no item I-B, diagnosticada por método definitivo $\mathbf{e}$

- uma contagem de linfócitos T4 (CD4) menor que 400 células por milimetro cúbico. 


\section{ANEXO 2}

\section{SISTEMA DE CLASSIFICAÇÃO PARA A INFECÇÃO PELO HIV EM ADULTOS ${ }^{19}$}

GRUPO I- Infecção aguda pelo HIV

Síndrome mononucleose-símile com ou sem meningite asséptica, associada à seroconversão para o HIV;

GRUPO II- Infecção assintomática pelo HIV

Ausência de sinais e sintomas da infecção pelo HIV. Os pacientes deste grupo devem ser subclassificados com base em parâmetros laboratoriais como um hemograma completo, com diferencial do leucograma e contagem de plaquetas, e contagem da células $\mathrm{CD} 4+\mathrm{e} C \mathrm{CD} 8+$.

GRUPO III- Linfadenopatia persistente generalizada

Linfadenopatia palpável, com gânglios de $1 \mathrm{~cm}$ ou mais em dois ou mais sítios extra-inguinais persistindo por mais de três meses, na ausência de qualquer doença ou condição concomitante à infecção pelo HIV. Deve-se subclassificar por parâmetros laboratoriais como no Grupo II.

GRUPO IV- Outras doenças induzidas pelo HIV

Linfadenopatia não é pré-requisito para a inclusāo. 
Subgrupo A - Doença constitucional

Um ou mais de:

- Febre persistindo por mais de um mês

- Perda de peso involuntária maior que $10 \%$

- Diarréia persistindo por mais de um mês

Subgrupo B - Doença neurológica

Um ou mais de:

- Demência

- Mielopatia

- Neuropatia periférica

Subgrupo C- Doenças infecciosas secundárias

Diagnóstico de uma doença infecciosa associada à infecção pelo HIV e ao menos moderadamente indicativa de um defeito na imunidade mediada por células.

Categoria C-1 Doenças infecciosas secundárias específicas listadas na definição de AIDS pelo CDC

Qualquer das seguintes :

- Pneumonia por Pneumocystis carinii

- Criptosporidiose crônica

- Toxoplasmose

- Estrongiloidíase extra-intestinal

- Isosporíase

- Candidíase (esofageana, brônquica ou pulmonar)

- Criptococose

- Histoplasmose 
- Infecção por micobactérias atípicas como as do complexo Mycobacterium avium-intracellulare ou M. Kansasii

- Infecção por Cytomegalovírus

- Herpes simples mucocutâneo crônico ou disseminado

- Leucoencefalopatia multifocal progressiva

- Tuberculose

- Bacteremia recorrente por Salmonella

Categoria C-2 Outras doenças infecciosas secundárias especificadas Qualquer das seguintes :

- Leucoplasia pilosa oral

- Herpes-zoster multidermatomal

- Nocardiose

- Candidíase oral

Subgrupo D- Neoplasias secundárias listadas pelo CDC

Qualquer das seguintes:

- Sarcoma de Kaposi

- Linfoma não-Hodgkin - de células pequenas, não clivadas ou sarcoma imunoblástico

- Linfoma primário do cérebro

Subgrupo E- Outras condiçōes

Presença de outros achados ou doenças clínicas, não classificáveis acima, que possam ser atribuídas à infecção pelo HIV e/ou possam ser indicativas de um defeito na imunidade de mediada por células. 


\section{ANEXO 3}

\section{REVISÃO DA DEFINIÇÃO NACIONAL DO CASO DE AIDS EM ADULTOS $^{68}$}

A nova definiçāo proposta pelo Ministério da Saúde foi organizada em dois critérios não exclusivos (critérios A e B), a partir da existência de evidências laboratoriais para a infecção pelo HIV.

\section{CRITÉRIO A:}

O critério A permite a definição de um caso de AIDS através do reconhecimento de um conjunto de sinais e sintomas/doenças.

Os sinais e sintomas/doenças incluídos neste critério foram identificados preliminarmente através de estudo conduzido no Brasil em 1989 ( MS em colaboração com o $\mathrm{CDC}$ ) e posteriormente classificados em uma escala de pontos em reunião organizada pela OPAS em Caracas.

\section{CRITÉRIO B:}

O critério B permite a definiçāo de um caso de AIDS através do diagnósticos de doença indicativa de AIDS. Entre estas, com evidências laboratoriais de infecção, aceita-se a caracterização das seguintes doenças:

- Pneumonia por Pneumocystis carinii

- Toxoplasmose cerebral

- Retinite por citomegalovírus

- Herpes simples muco-cutâneo

- Candidiase do esôfago

Um terceiro critério, considerado como excepcional, se aplica a indivíduos 
com teste laboratorial para o HIV não realizado ou de resultado desconhecido e só permite a definiçāo de um caso de AIDS através de diagnóstico definitivo de doença indicativa de AIDS (por exemplo, identificação de agente etiológico com microscopia) e exclusão de outras causas de imunodeficiência que nāo a própria infecção pelo HIV. Este critério se aplica para a notificação de casos após o óbito.

\section{CASO CONFIRMADO DE AIDS}

Para efeito de notificação ao Ministério da Saúde, será considerado caso de AIDS:

Todo adulto que apresente evidências laboratoriais de infecção pelo $\mathrm{HIV}^{(1)}$ e, independentemente da presença de outras causas de imunodeficiência:

A-Um conjunto de sinais e sintomas /doenças que somem pelo menos 10 pontos segundo o critério OPAS/Caracas exposto a seguir (item 1 critério de pontuação, página A-11)

e/ou

B- Pelo menos uma doença indicativa de AIDS, incluindo Pneumonia por Pneumocystis carinii, toxoplasmose cerebral, herpes simples muco-cutâneo com duração de mais de 1 mês, retinite por citomegalovirus e candidiase esofágica diagnosticadas presuntivamente (critério CDC modificado item 2.1, página A-11).

(1) No contexto de vigilåncia epidemiológica de casos de AIDS, evidência laboratorial existe quando uma amostra de soro é repetidamente reativa em um teste para pesquisa de anticorpos anti-HIV (por exemplo ELISA) e/ou apresenta um teste positivo para antigeno e/ou cultura positiva. 


\section{CRITÉRIO EXCEPCIONAL :}

Será considerado caso de AIDS todo adulto com teste laboratorial para o HIV não realizado ou de resultado desconhecido e que apresente pelo menos uma doença indicativa de AIDS diagnosticada definitivamente (critério do CDC modificado item 2.2, página A-13), desde que excluídas as seguintes causas de imunodeficiência:

Corticoterapia sistêmica em altas doses ou de longo termo ou outra terapia imunossupressiva/citotóxica iniciada pelo menos 3 meses antes do diagnóstico da doença indicativa;

Pelo menos uma das seguintes doenças diagnosticadas em até 3 meses após o diagnóstico da doença indicativa :

Hodgkin, linfoma nāo-Hodgkin (outro que não o linfoma primário do cérebro), leucemia linfocítica, mieloma múltiplo, qualquer outro câncer do tecido linforreticular ou histiocítico, linfadenopatia angioimunoblástica.

Síndrome de imunodeficiência genética (congênita) ou de uma síndrome de imunodeficiência, que não seja pelo HIV, como a que envolve hipogamaglobulinemia. 


\section{CRITÉRIO DE PONTUAÇÃO OPAS/CARACAS}

SINAIS / SINTOMAS/ DOENÇAS

PONTOS

Sarcoma de Kaposi

Tuberculose disseminada/extrapulmonar/pulmonar não cavitária

Candidíase oral ou leucoplasia pilosa

Tuberculose pulmonar ou não especificada

Herpes Zoster em indivíduo $\leq 60$ anos

Disfunçāo do sistema nervoso central

Diarréia $\geq 1$ mês

Febre $\geq 38^{\circ} \mathrm{C} \geq 1$ mês

Caquexia ou perda de peso $>10 \%$

Astenia $\geq 1$ mês

Dermatite persistente

Anemia e/ou linfopenia e/ou trombocitopenia

Tosse persistente ou qualquer pneumonia (exceto tuberculose)

Linfadenopatia $\geq 1 \mathrm{~cm}$ em 2 ou mais locais extra-inguinais, por pelo menos 1 mês

\section{CRITÉRIO CDC MODIFICADO}

2.1 Com evidência laboratorial de infeç̧ão pelo IIIV e independentemente da presença de outras causas de imunodeficiência :

As seguintes doenças serão consideradas indicativas de AIDS se diagnosticadas por método definitivo (item 3, página A-14) ou presuntivo (item 4, página A-14):

- Pneumonia por Pneumocystis carinii

- Toxoplasmose cerebral

- Retinite por citomegalovirus

- Herpes simples muco-cutâneo > 1 mês

- Candidíase do esôfago 
As seguintes doenças serão consideradas indicativas de AIDS se diagnosticadas exclusivamente por método definitivo (item 3, página A-14):

- Isosporíase com diarréia persistente por mais de 1 mês

- Criptosporidíase com diarréia persistente por mais de 1 mês

- Citomegalovirose em local que não o olho, e além do fígado, baço ou linfonodos

- Herpes simples dos brônquios, pulmão ou do trato gastro-intestinal

- Leucoencefalopatia multifocal progressiva

- Candidiase da traquéia, brônquios ou pulmão

- Criptococose extrapulmonar

- Histoplasmose disseminada (em órgãos outros que não o pulmão ou linfonodos cervicais ou hilares, ou em um desses órgãos associado a qualquer outra localização)

- Coccidioidomicose disseminada (em órgãos outros que não o pulmão ou linfonodos cervicais ou hilares, ou em um desses órgãos associado a qualquer outra localização)

- Septicemia recorrente por Salmonela (nāo tifóide)

- Qualquer micobacteriose disseminada que não seja tuberculose (em órgāos outros que nāo o pulmão, pele ou linfonodos cervicais ou hilares, ou em um desses órgãos associado a qualquer outra localização)

- Linfoma primário do cérebro em qualquer idade

- Outro linfoma não-Hodgkin de células B ou fenótipo imunológico desconhecido e dos seguintes tipos histológicos:

a- linfoma maligno de células não clivadas ( tipo Burkitt)

b- linfoma maligno imunoblástico (termos equivalentes: linfoma de células grandes imunoblástico, linfossarcoma imunoblástico, sarcoma imunoblástico, linfoma "High-grade")

NOTA: Não estāo incluídos linfomas de células $T$ (fenótipo imunológico) ou de tipo histológico não descrito ou descrito como "linfocítico", "linfoblástico", "células pequenas não clivadas " ou " linfoplasmocítico". 
2.2 Com teste laboratorial para o HIV não realizado ou de resultado desconhecido desde que excluídas outras causas de imunodeficiência

As seguintes doenças serāo consideradas indicativas de AIDS se diagnosticadas exclusivamente por método definitivo (item 3, página A-14):

- Pneumonia por Pneumocystis carinii

- Toxoplasmose cerebral

- Criptosporidíase com diarréia persistente por mais de 1 mês

- Citomegalovirose em local que não ou além do fígado, baço ou linfonodo

- Herpes simples muco-cutâneo por mais de 1 mês, dos brônquios, pulmão ou trato gastrointestinal

- Leucoencefalopatia multifocal progressiva

- Candidíase do esôfago, traquéia, brônquios ou pulmão

- Micobacteriose disseminada por Mycobacterium avium complex ou M. kansasii ( em órgãos outros que não o pulmão, pele ou linfonodos cervicais ou hilares, ou em um desses órgãos associado a qualquer outra localização)

- Linfoma primário do cérebro em pacientes > 60 anos

- Sarcoma de Kaposi em pacientes com menos de 60 anos. 


\section{MÉTODOS DIAGNÓSTICOS DEFINITIVOS PARA DOENÇAS INDICATIVAS DE AIDS}

\section{DOENÇAS}

Pneumonia por $P$. carinii

Toxoplasmose cerebral

Isosporíase

Criptosporidiase

Citomegalovirose

Leucoencefalopatia multifocal progressiva

Sarcoma de Kaposi

Linfoma

Candidíase

Herpes simples

Criptococose

Histoplasmose

Coccidioidomicose

Micobacteriose (nāo tuberculose)

Salmonelose

\section{MÉTODO DIAGNóSTICO}

microscopia
Inspeção macroscópica através de endoscopia ou microscopia (histologia ou citologia) em material obtido diretamente do tecido afetado

microscopia (histologia ou citologia) cultura ou detecçāo de antígeno em material obtido diretamente do tecido afetado ou de fluidos destes tecidos

cultura

\section{CRITÉRIOS SUGERIDOS PARA DIAGNÓSTICO PRESUNTIVO DE DOENÇAS INDICATIVAS DE AIDS}

Pneumonia por Pneumocystis carinii

- História de dispnéia de esforço ou tosse não produtiva de início recente (dentro dos últimos 3 meses)

- Rx de tórax com evidências de infiltrado intersticial difuso bilateral e

- ausência de evidências de pneumonia bacteriana (prova terapêutica é suficiente) 
Toxoplasmose cerebral:

- Início recente de anormalidade neurológica focal compativel com lesão intracraniana ou redução do nível de consciência $\mathrm{e}$

- Imagem de lesāo cerebral com efeito de massa (tomografia computadorizada ou ressonância nuclear magnética) ou aparência radiológica positiva após injeção de contraste e

- sorologia ou prova terapêutica positiva

Retinite por citomegalovirus:

- Aparência característica em exames oftalmológicos seriados (por exemplo placas na retina com bordas distintas, progredindo de modo centrífugo, acompanhando os vaso sanguíneos e frequentemente associadas com vasculite retiniana, hemorragia e necrose). Resolução da doença ativa deixa cicatriz e atrofia com mosqueamento (mottling) do pigmento retiniano.

Herpes Simples Muco-cutâneo:

- Aparência característica de lesōes úlcero-crostosas persistentes por mais de 1 mês, por vezes muito extensas, nas regiōes perianal e genital. Prova terapêutica deverá ser considerada nos casos duvidosos.

Candidíase do Esôfago:

- Início recente de dor retroesternal e

- Candidíase oral diagnosticada pelo achado macroscópio de placas brancas em base eritematosa removíveis na mucosa oral. 